\title{
Cheap Talk and the Efficacy of the ECB's Securities Market Programme: Did Bond Purchases Matter?
}

De Pooter, Michiel, Rebecca DeSimone, Robert F. Martin, and Seth Pruitt

Please cite paper as:
De Pooter, Michiel, Rebecca DeSimone, Robert F. Martin, and
Seth Pruitt (2015). Cheap Talk and the Efficacy of the ECB's
Securities Market Programme: Did Bond Purchases Matter?
International Finance Discussion Papers 1139.
http://dx.doi.org/10.17016/IFDP.2015.1139

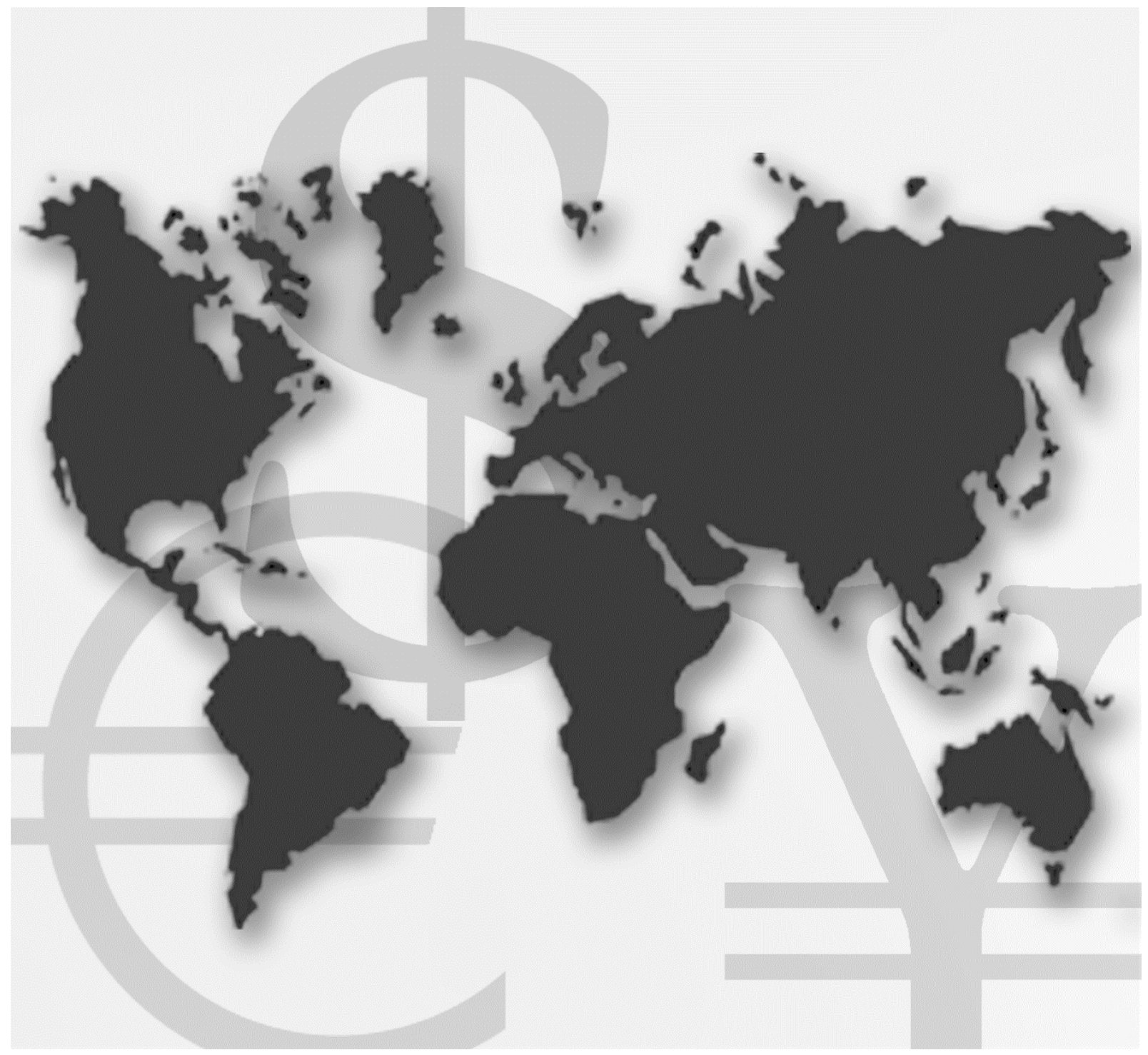

\section{International Finance Discussion Papers}

Board of Governors of the Federal Reserve System

Number 1139

July 2015 
Board of Governors of the Federal Reserve System

International Finance Discussion Papers

Number 1139

July 2015

\title{
Cheap Talk and the Efficacy of the ECB's Securities Market Programme: Did Bond Purchases Matter?
}

\author{
Michiel De Pooter \\ Rebecca DeSimone \\ Robert F. Martin \\ Seth Pruitt
}

NOTE: International Finance Discussion Papers are preliminary materials circulated to stimulate discussion and critical comment. References to International Finance Discussion Papers (other than an acknowledgment that the writer has had access to unpublished material) should be cleared with the author or authors. Recent IFDPs are available on the Web at www.federalreserve.gov/pubs/ifdp/. This paper can be downloaded without charge from the Social Science Research Network electronic library at www.ssrn.com. 


\title{
Cheap Talk and the Efficacy of the ECB's Securities Market Programme: Did bond purchases matter?
}

\author{
Michiel De Pooter ${ }^{1}$ \\ Rebecca DeSimone ${ }^{2}$ \\ Robert F. Martin ${ }^{3}$ \\ Seth Pruitt ${ }^{4}$
}

First draft: May 1, 2014

This draft: April 13, 2015

\begin{abstract}
In 2010, in response to an ever-worsening fiscal crisis, the ECB began purchasing sovereign debt from troubled euro-area countries through its Securities Market Programme (SMP). This program was designed to improve market functioning and restore the monetary transmission mechanism within the euro area. This paper does not test those ideals. Rather, we test whether SMP purchases systematically lowered peripheral yields and spreads. We find limited evidence of purchase effects but large announcement effects. In addition, on days in which the ECB was believed to have made large purchases, yields moved down, independent of the size of the ECB's purchases or even if the ECB conducted any purchase at all that week. In all, we conclude that the ECB's SMP influenced yields through a confidence channel rather than through any direct purchase effect. In the appendix to this paper we provide a detailed timeline of SMP purchases and market beliefs about purchase timing.
\end{abstract}

Keywords: monetary policy, interest rates, recession, European Central Bank, asset purchases, euro area JEL Classifications: E20, E52, E43, F44

\footnotetext{
${ }^{1}$ Division of International Finance, Federal Reserve Board of Governors, $20^{\text {th }}$ Street and Constitution Ave, NW, Washington, D.C. 20551, ${ }^{2}$ Columbia Business School, 3022 Broadway, New York, NY 10027, ${ }^{3}$ Barclays Capital, $7457^{\text {th }}$ Avenue, New York, NY 10019, ${ }^{4}$ W.P. Carey School of Business, Arizona State University, 400 East Lemon Street, Tempe. AZ 85287. Corresponding author: Rebecca DeSimone, red2139@columbia.edu. The views in this paper are solely the responsibility of the authors and should not be interpreted as reflecting the views of the Board of Governors of the Federal Reserve System or of any other person associated with the Federal Reserve System.
} 


\section{Introduction}

Ia. Large-Scale Asset Purchases - a response to crisis

After the Great Recession began in late 2007, the central banks of the hard-hit advanced economies dropped policy rates towards an effective zero lower bound until they could meaningfully ease no further. Having exhausted the effectiveness of their main policy transmission tool while market stress continued and their economies either grew anemically or remained in recession, the Federal Reserve (Fed), the Bank of England (BOE), the European Central Bank (ECB), and the Bank of Japan (BOJ) all established some form of asset purchase program. These programs vary in design, but all involve the targeted large scale purchases of government bonds, government-backed securities, and/or private-market assets. For example, the Federal Reserve conducted two Large-Scale Asset Purchase programs, a Maturity Extension Program, and in October 2014 concluded its most recent program which consisted of conducting open-ended purchases at a steady pace per month. Together, these programs have more than tripled the Federal Reserve's balance sheet (see the first panel of Figure 1). Similarly, the Bank of England purchased $£ 375$ billion of government securities through its Asset Purchase Facility, established in January 2009. ${ }^{1}$ Although differing in nature, the aim was, generally, the same: to replicate the liquidity-providing effects of conventional monetary policy by influencing expected short-term interest rates, and in particular, to enhance the liquidity in these particular markets, thereby increasing their market valuations.

Despite the vigor with which these central banks embraced unconventional policy, the transmission mechanisms, and therefore the efficacy, of such actions are only marginally understood at best. Even amongst those who fervently believe that the programs have been effective, there has been considerable debate over the channels through which the programs work. In large part this debate arises because most mainstream macroeconomic models (including the large-scale DSGE models favored by central banks) feature perfect asset substitution. This feature of those standard models essentially precludes central bank actions from influencing relative asset prices_-at least for asset purchases on the scale currently considered by central banks. As a result, model-based studies of central bank actions must rely

\footnotetext{
${ }^{1}$ http://www.bankofengland.co.uk/markets/Pages/apf/default.aspx. See also Fawley and Neely (2013) for a detailed timeline of the asset purchase programs of the Fed, the BOE, the ECB, and the BOJ.
} 
on frictions layered on top of the model. The empirical tests driven by the studies are then reliant on the underlying structural assumptions.

\section{Figure 1: Central bank balance sheets as a percent of gross domestic product}

Federal Reserve

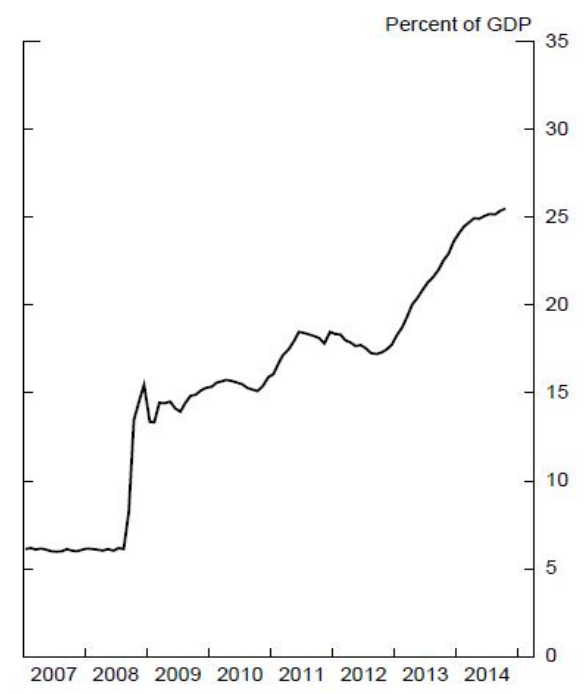

Bank of England

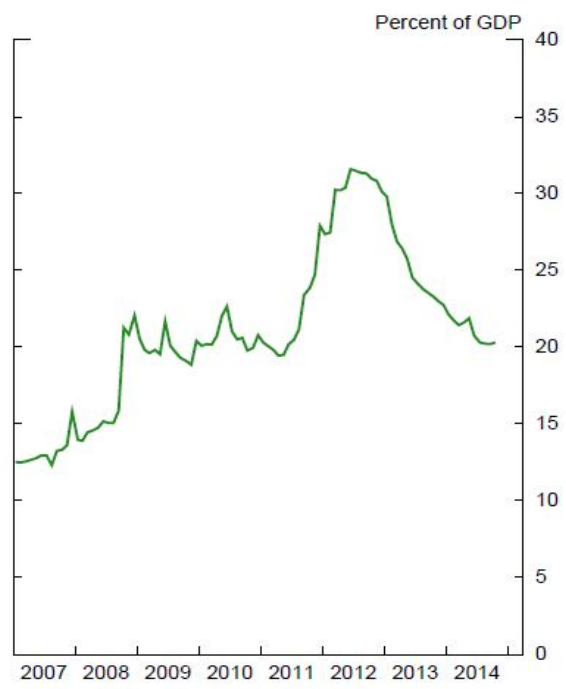

Nonetheless, a literature has emerged to study the efficacy of central bank asset purchases during the Great Recession of 2007-2009. ${ }^{2}$ These studies are, for the most part, empirical studies that examine the movements of bond yields in the days and months surrounding purchases. That is, the dominant approach has been the event study. By focusing on the changes in yields over fairly short periods of time, the studies can reduce the influence of other factors on yields. The consensus emerging from these studies is that central bank purchases of assets reduce benchmark yields between 10 and 20 basis points for every 1 percent of GDP purchased. Of course, shortlived movements in yields are likely not economically meaningful and these declines must be sustained for the policies to be truly effective.

However, once the time period is extended, many other factors influence yields. For example, D’Amico and King (2013) find that the Federal Reserve’s holdings of Treasuries have a permanent influence on the level of yields. This is the so called stock effect. However, these bond yields may be influenced by many factors and these studies lack a benchmark that can

\footnotetext{
${ }^{2}$ See Gagnon et al. (2011) and D’Amico and King (2013) for the effect of the first Large-Scale Asset Purchase program in the US and Joyce et al. (2011) for analysis of the effect of quantitative easing (QE) in the UK. See Gambacora et al. (2012) for a cross-country comparison of unconventional policies taken by the ECB, the Fed, the BOE, and the BOJ as well as actions in China, Switzerland, Norway and Canada to combat the impact of the Great Recession on their economies.
} 
inform on the evolution of fundamentals. For example, the European debt crisis is thought to have led to substantial flights to safety and large purchases of U.S. bonds. According to more recent work by Martin (2013), these flows themselves should have an influence on yields at least as large as that of the Fed's purchases. In other words, researchers studying the long term effect of asset purchase programs do not have any fundamental way of understanding the counterfactual — the movement of yields absent central bank purchases. In addition, viewed through a longer lens, the decline in yields between 2010 and 2013 is well aligned with the longterm decline in yields that some attribute to the evolution of demographics over time (Martin 2005 and Figure 2).

Figure 2: The decline in long-term interest rates in the United States

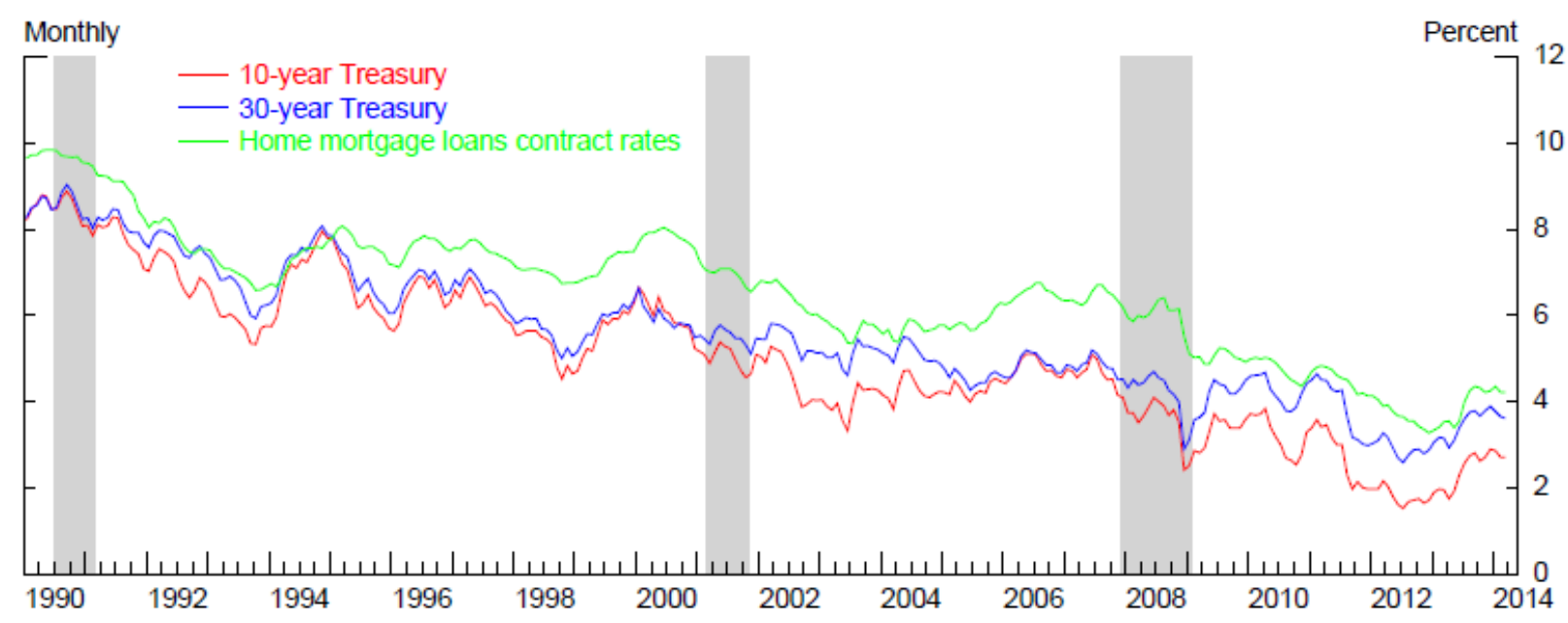

Note: Shaded areas are from the peak to trough of U.S. recession periods (Source: NBER)

We believe that studying the ECB's Securities Market Programme (SMP) provides an ideal laboratory for studying the long-term efficacy of central bank asset purchases. Because of the structure of the European monetary union and because the ECB did not purchase German bonds during the program, German bonds serve as an appropriate benchmark, effectively controlling for fluctuations in real interest rates. We further believe that the lessons learned from the SMP can help us understand the (likely) impact of government bond purchases that the ECB is currently conducting under its Public Section Purchase Program. ${ }^{3}$

\footnotetext{
3 The PSPP was announced on January 22, 2015 and consists of the combined monthly purchases of $€ 60$ billion in public and private sector securities, with purchases intended to be carried out until at least the end of September 2016.
} 


\section{Ib. The ECB's Securities Market Programme (SMP)}

The ECB established the SMP on May 10, 2010 in response to the European Debt Crisis then beginning to become apparent in Greece, and soon also in Portugal, and Ireland. Speculation was growing that one or all of these countries would be forced out of the monetary union, increasing capital outflows from southern to northern Eurozone members, fragmenting credit markets across national borders, and lowering consumer and investment demand. These effects passed through to the real economy, lowering output and employment and negatively impacting bank balance sheets and public finances.

The first phase of the program spanned May 2010 to April 2011 and consisted of purchases of Greek, Irish, and Portuguese debt. The program was then mostly inactive during the relative market calm of the summer of 2011, purchasing small amounts of Portuguese debt on two isolated occasions. On August 7, 2011, in response to rising peripheral borrowing costs and when markets began to question the creditworthiness of Italy and Spain, the ECB officially announced it would "actively implement" its bond-buying program again after the nearly fourmonth pause. ${ }^{4}$ From here on we shall refer to the period from May 2010 to August 2011 as the first SMP and the period from August 2011 to the Friday of the last week of purchases, February 10, 2012, as the second SMP. This characterization is useful to us for ease of reference but the distinction has no basis in how either the ECB or market participants discussed and thought about the program at the time; there was only one SMP.

The official intervention in European bond markets under the SMP had the explicit goal of ensuring "depth and liquidity" in "dysfunctional” markets. The ECB believed that sovereign bond markets in certain euro-area countries were no longer functioning well. The specified goal of the intervention was to improve liquidity conditions in specific markets without changing the fundamental value of the asset or the euro-wide discount rate, which we read as German bond yields.

Importantly, the purchase program had no pre-announced size or maturity distribution (in contrast to almost every other program, including to a certain degree the ECB's PSPP, and especially those of the Federal Reserve and Bank of England) and therefore to an extent each individual purchase was an exogenous surprise to market participants in the week in which they

\footnotetext{
${ }^{4}$ http://www.ecb.europa.eu/press/pr/date/2011/html/pr110807.en.html
} 
occurred. SMP purchases of varying sizes occurred in dozens of weeks, often consecutively, in several European sovereign bond markets over the course of almost two years. Some market commentary claimed that the SMP was a failure because a large number of consecutive purchases were deemed necessary, yet peripheral bond spreads often rose soon after the ECB stepped out of the market.

The SMP differed from other major central bank programs because the ECB did not focus on changing the term structure of their risk-free rate. Rather, the program focused on reducing peripheral European spreads over the German bond rate, which itself already contains a term premium. Furthermore, the ECB was dealing with credit-impaired sovereigns. Thus, not only did the ECB's methods differ from comparable programs but the channels by which the SMP acted upon the market are distinct. We are able to use the unique structure of the ECB's purchases - the risk free asset was not directly purchased (indeed SMP purchases were sterilized), there is time variation in the purchases of bonds-as well as special characteristics of European markets — all purchased bonds were issued in the same currency and often trade on the same exchanges. The purchases thus provide, in many ways, an ideal laboratory for studying the channels through which quantitative easing works.

Empirically, we test for both stock and flow effects. We find that the SMP purchases had no systematic influence on bond yields. The change in yields over ECB purchase weeks neither varies with the size of the purchases nor does it vary systematically between days in which the ECB makes purchases and days in which it does not. This result is robust whether we look at individual country responses to purchases or to panel data responses.

We do, however, observe large announcement effects. Yields on Spanish and Italian 10year spreads over German Bunds, for example, dropped 67 and 46 basis points respectively from the end-of-day value on Friday May 7, 2010 to end-of-day on Monday, May 10, 2010, the day of the announcement of the first SMP. Similarly, Italian yields fell approximately 36 and Spanish yields approximately 38 basis points from end-of-day Friday, August 5, 2011 to end-of-day Monday, August 8, 2011, the day after the announcement of the second SMP on Sunday, August 7, 2011 (see Figure 9). Most previous work, including De Pooter et al. (2014), the companion paper to this study, has included these declines in the overall tests of efficacy. They argue that the decline in yields owes to market expectations of the overall size of the purchase program. In other words, efficient financial markets price the total size of the program from the outset. 
This explanation is possible but we discount it for three reasons. First, the ECB never announced either a target size or a time frame for purchases, stating instead that purchases would be made on an as-needed basis to maintain proper market functioning. We would, a priori, expect this uncertainty to, at a minimum, dilute the announcement effect. Second, and more importantly, the change in yields following the two announcements was broadly similar. Yet, on the introduction of the first SMP market participants clearly did not have any expectation of Spanish or Italian bond purchases_-and these expectations were fully met. The second SMP was explicitly about the expansion of the program to include these two countries. Given this, the yield response to the two events should have been very different.

Third, we find limited evidence that market beliefs about ECB intervention do matter for yields. Following market chatter in which market participants report large ECB intervention, yields decline significantly. This decline occurs whether or not the ECB actually made any purchases during the time frame.

Finally, and distinct from the other reasons we state, yields also dropped after the ECB announced the Outright Monetary Transactions (OMT) program on August 2, 2012 (the same day the SMP was officially terminated). The OMT is a program where, under defined conditions and after a Eurozone country requests aid, the ECB can make purchases in short-term secondary European sovereign bond markets using funds from the European Stability Mechanism and the European Financial Stability Facility until the ECB decides that the program's “objectives are achieved". ${ }^{5}$ The OMT has never been activated and most ECB watchers (both contemporaneously and to this date) believe that there are substantial legal hurdles to overcome before the OMT could become operational. Yet, the yield response to the OMT announcement was large and sustained.

In all, these findings lead us to conclude that the efficacy of the SMP arose not from the size or timing of the purchases but rather from a communications or a confidence channel. Perhaps market participants genuinely believed that there was a substantial risk of euro-area dissolution - in which case, the debt would more likely be redenominated or defaulted upon. Or perhaps, they read the ECB's announcements as a willingness of central European authorities to take on the credit risk of the smaller countries. In any event, understanding this channel rather

\footnotetext{
${ }^{5}$ http://www.ecb.europa.eu/press/pr/date/2012/html/pr120906_1.en.html
} 
than trying to quantify the elasticity of the purchase effect is likely to be a fruitful avenue of future research.

\section{Literature Review}

Our paper is related to the empirical literature on the effectiveness of non-traditional monetary policy over the period 2007-2012. ${ }^{6}$ However, the unconventional monetary policy literature begins in the early 2000s in the context of Japanese quantitative easing. It considers whether central banks can achieve their monetary policy goals with techniques other than interest-rate targeting when interest rates are effectively zero. The unconventional monetary policy option that we consider are asset purchase, or quantitative easing (QE), programs such as the Fed's LSAPs, the BOE's QE program and the ECB's SMP. The theoretical basis for the potential efficacy of asset purchase programs is mixed. On the one hand, Eggertsson and Woodford (2004) claim that open-market operations will be largely ineffective because they cannot change expectations regarding future monetary policy. However, subsequent theoretical studies assert that their neutrality result does not hold if assets are not seen as perfect substitutes by investors, if investors are heterogeneous, if there are credit constraints, limited financial market participation or distortionary taxes (see, for example, Andres et al. 2004, Curdia and Woodford 2011).

The most common theoretical explanation for potential effectiveness of asset purchase programs is the "portfolio balance channel” as in Tobin (1961, 1963, 1969) and Brunner and Meltzer (1973). In this channel, central banks influence yields by varying the relative supplies of assets with different maturities which are imperfect substitutes. Agents are heterogeneous and come to hold different portfolios. Kiyotaki and Moore (2012) assert the efficacy of a portfolio balance channel in a model of a monetary economy where financial assets differ in their liquidity so open market operations work by changing the mix of assets held by the private sector after a liquidity shock.

Another suggested channel through which asset purchase programs could affect the real economy are the preferred-habitat theories of Modigliani and Sutch (1966) and Vayanos and

\footnotetext{
${ }^{6}$ Joyce, Miles, Scott, and Vayanos (2012) give a review of non-standard monetary policy measures taken by major central banks from the wake of the financial crisis in 2007. They review both theoretical and empirical studies on the effectiveness of central bank asset purchases. For Europe, they do not count the SMP as QE, since the balance sheet of the ECB was not expanded. Rather, they focus on the ECB’s long-term repo operations in response to large intra-euro-area bank-funding imbalances.
} 
Vila (2009); models in which investors have a preference for a particular segment of the yield curve. Central bank long-term asset purchases reduce the average duration of the stock of bonds held by the private sector which may lower the premium required to hold duration risk.

The effects of the Federal Reserve's LSAP programs and the Bank of England's QE program are often attributed to the portfolio balance channel. However, the SMP program's effects likely worked through different channels since the design of the SMP differed greatly from the programs of other central banks. De Pooter et al. (2014) use a search model to describe a 'liquidity' or 'market-functioning' channel in the context of the European Central Bank's Securities Market Programme (SMP). The ECB explicitly designed its program to improve the functioning of 'dysfunctional' sovereign markets. Asset purchase programs may also affect the prices of longer-term assets if the presence of the central bank, as a consistent and significant buyer in the market, enhances market functioning and liquidity. By providing an ongoing source of demand for the sovereign bonds of stressed European nations, the SMP allowed investors to take larger positions in these assets knowing that they could sell them if needed to the European Central Bank. This could reduce the liquidity risk premiums embedded in asset prices, thereby lowering their yields. This liquidity, or market functioning, channel is distinct from the portfolio balance channel.

Most empirical studies of unconventional monetary policy since the recession of 20072009 have focused on the actions of the Federal Reserve. Besides its status as the central bank of the world's largest economy, this focus is also the result of the Fed's exceptionally transparent market operations. On one extreme, the ECB did not reveal what or when it was buying at all under the SMP except for a weekly aggregate of the purchase amounts. In contrast, the Fed was open about exactly what assets it purchased, in what quantities, and on what days.

Gagnon et al. (2011) find that the Fed's Large Scale Asset Purchase (LSAP) purchases reduced the 10-year term premium on U.S. Treasuries and estimate the size of the reduction to be “somewhere between 30 and 100 basis points." Hamilton and Wu (2012) and Neely (2010) both find an effect of similar magnitude, the former indirectly with a term structure model of U.S. debt and the latter using event-study methodology. Gagnon et al. (2011) investigates the channels through which purchases affected yields and cite a 'duration channel' which is a special case of the Vayanos and Vila (2009) model and a 'market functioning' channel similar to the one use in De Pooter et al. (2014). 
D'Amico and King (2012) use cross-section data on the yields of all outstanding Treasury securities and find that the interest rates of those assets purchases by the LSAP program fell more than yields on those not purchased. They find a significant and permanent reduction from the LSAP on medium- and long-term Treasury yields. They also find a small temporary flow effect from Federal Reserve purchases. Meaning and Zhu (2011) use the methodology of D'Amico and King (2012) and find that LSAP2 purchases lowered the yield curve by a smaller magnitude than that found by D'Amico and King from the first LSAP, both in the short- and the long-term, even though the second round of Treasury purchases was nearly twice as large. They attribute this difference to improved risk sentiment and better market functioning and liquidity.

D’Amico and King (2013) use a panel-data approach and the Vayanos-Vila (2009) preferred-habitat theoretical framework to find that, during the first LSAP, Treasury yields within a particular maturity sector responded more to changes in the amounts outstanding in that sector than to similar changes in other sectors. They attribute to this market segmentation a downward shift in yields both on the day of purchases as well as a persistent downward effect on yields of around 30 basis points.

By February 2010, the Bank of England had purchased 29 percent of the free float of gilts, making its quantitative easing program similar in size and scope to that of the Federal Reserve (see the second panel of Figure 1). Joyce, Lasaosa, Stevens and Tong (2011) investigate the impact of the BOE's quantitative easing policy on the UK gilt market. They found that the BOE's asset purchases depressed medium to long-term government bond yields by approximately 100 basis points, primarily from a portfolio balance effect. This bond yield effect is quantitatively similar to that reported by Gagnon et al. (2011) for the U.S. LSAP program. They found a larger reaction to earlier announcements of purchases than later.

Christensen and Rudebusch (2012) examines the effects of the Fed's and the BOE's asset purchase programs on short-term interest rate forecasts and term premia they extract from sovereign yields using the Kim and Wright (2005) dynamic term structure model. They attribute declines in U.S. yields to lower expectations of future short rates. The finding suggests that asset purchase programs are more of a complement to standard monetary policy than a substitute. But they find that the declines in U.K. yields reflected reduced term premiums. Thus the effects of asset purchase programs are intimately tied up with how they are structured. 
A broader study, Kozicki, Santor, and Suchanek (2011), uses time-series data to find that increases in central bank balance sheets are associated with declines in long-term forward interest rates and that this effect also holds for countries whose balance sheets expanded over the period but that did not implement quantitative easing programs.

\section{Data}

Our data run from the inception of the SMP in May 2010 to its dissolution in August 2012. The last week of recorded purchases is the week of Friday, February 10, 2012, but the SMP was officially terminated on the day the ECB announced its Outright Monetary Transactions (OMT) program on August 2, 2012. The OMT allows unlimited sovereign debt purchases of a specific country's debt under strict conditions. The program is extant but still unused at this time. The ECB has since begun purchasing euro-area sovereign bonds under its January-2015 announced Public Sector Purchase Programme.

The data are weekly; the frequency the ECB released its purchases on its balance sheet. We include Ireland, Portugal, Italy, and Spain. The ECB is known to have purchased sovereign debt through the SMP phases in these countries and in Greece. ${ }^{7}$ We exclude Greece to avoid complications surrounding the Greek default—and because the ECB stopped purchasing Greek debt fairly early in the program as it became clear that Greece would likely need to restructure its debt.

Although in our empirical analysis we will predominantly focus on 5-year yields, in order to have a full spectrum of constant maturity yields available for our analysis we construct nominal zero coupon yield curves for each country which are used in both our event-study and regression analysis below. Time series for these yields are shown in Figure 3. Our sovereign bond data is from Thomson Reuter's Datastream. We collect bond prices, maturity date, coupon rate, and coupon payment frequency for all bonds outstanding for every day in the sample. We apply several standard filters on the bond prices. We exclude bonds with option-like features, floating coupon payments, and all Treasury Bills.

We eliminate any bond in the estimation as soon as it has less than three months left to maturity. We then construct daily nominal zero coupon curves for each country and every day

\footnotetext{
7 In February 2013, the ECB released a snapshot of how much debt it was holding for each country at the end of December 2012. See http://www.ecb.europa.eu/press/pr/date/2013/html/pr130221 1.en.html.
} 
Figure 3a: 5-Year Peripheral European spreads

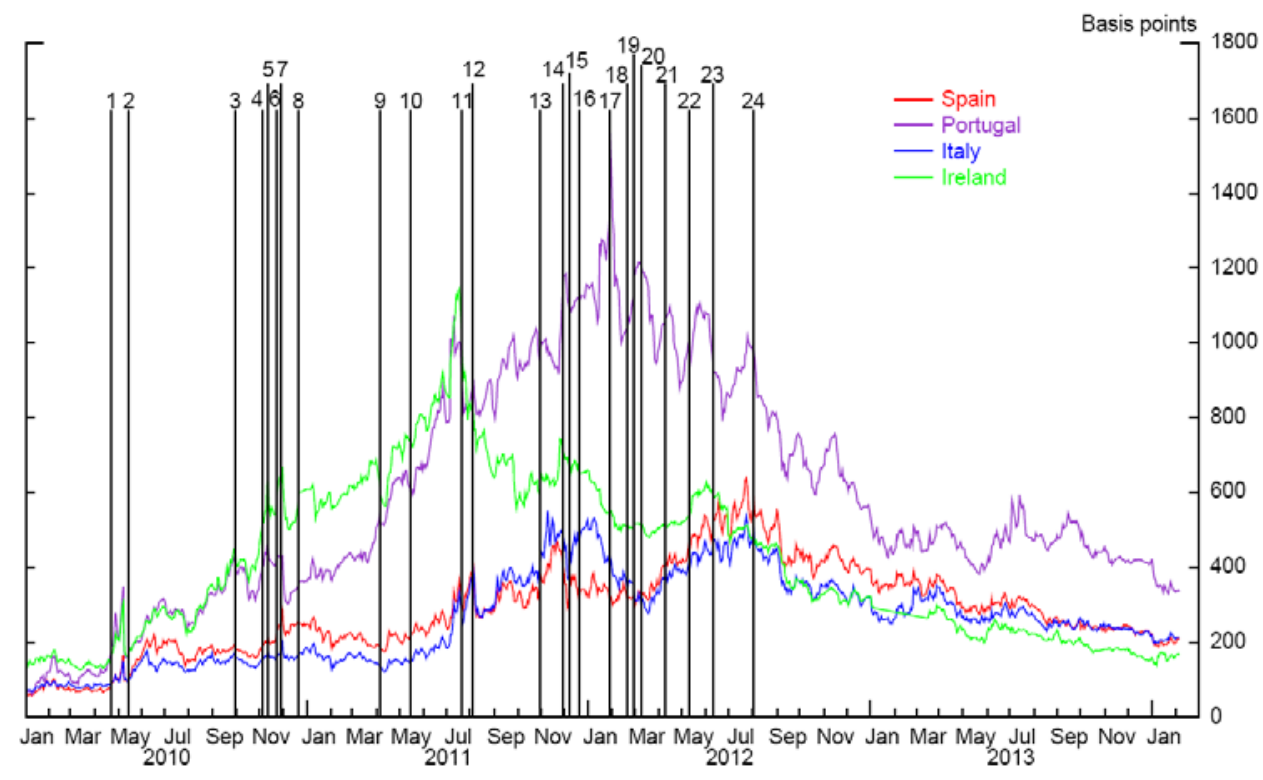

Figure 3b: 5-Year Yields

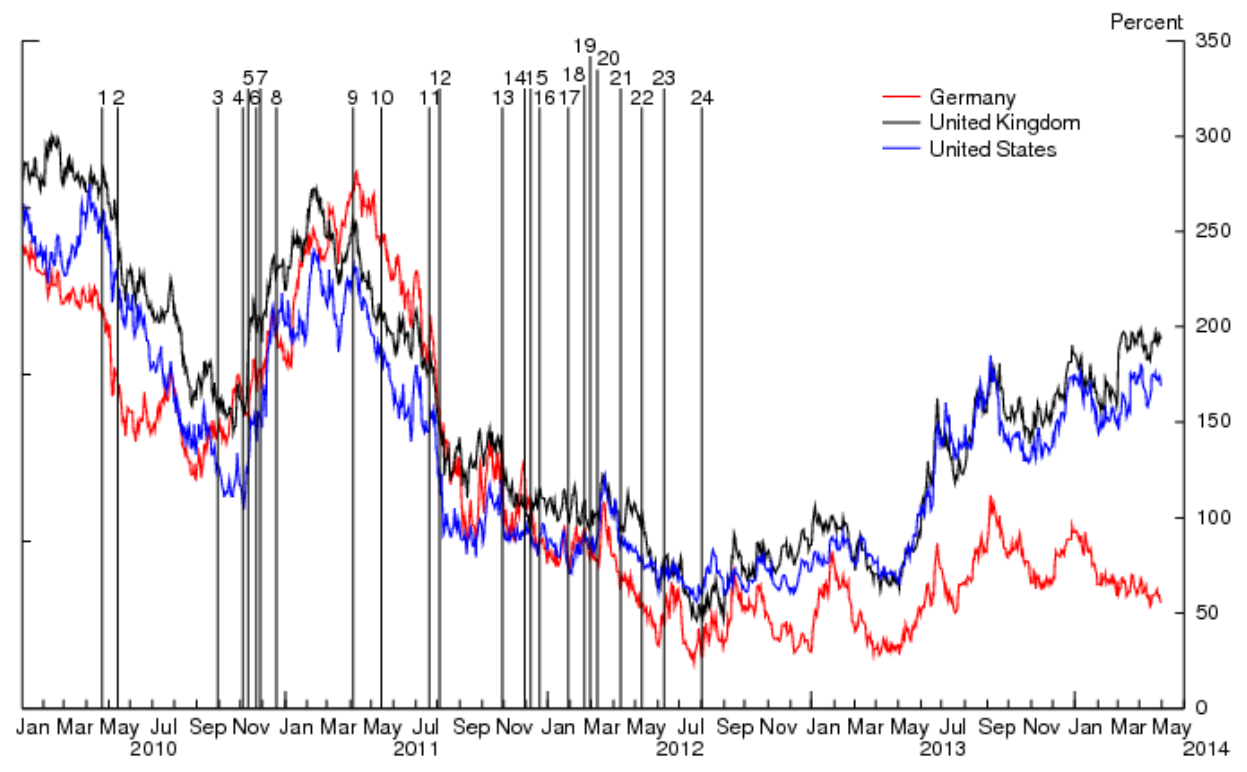

Vertical lines denote: 1.Greek 2009 deficit revised up; 2. Announcement of SMP; 3. Ireland's deficit rises steeply as supports banking sector; 4. Portugal loses market funding; 5. LCH.Clearnet increases Irish debt margin; 6. Ireland coalition government junior partner unexpectedly calls for elections; 7. Irish aid package; 8. Ireland recapitalizes major banks and subordinated debt holders take haircut; Spanish regions' finances revealed; 9. Fitch and Moody’s downgrade Portuguese debt to junk; 10. Portugal aid package; Greece may restructure its debt; 11. EU summit (second Greek aid package); 12. Expansion of SMP; 13. EU summit: Greek PM calls surprise referendum on second bailout; 14. Fed and ECB swap line arrangement expands; 15. ECB meeting: additional easing measures (LTRO); 16. First LTRO; 17. EU summit ( fiscal compact); 18. Second Greek aid package; 19. Second, three-year LTRO; 20. Greece achieves quorum of private bondholders to restructure its debt; 21. Greek PM steps down; 22. Greece fails to form a coalition government; Spain nationalizes Bankia; 23 EU Spanish bank rescue package; and 24. Announcement of the OMT and official termination of the SMP. 
using a modified version of the parametric curve-fitting approach of Nelson and Siegel (1987). We estimate the zero-coupon curves by minimizing the sum of squared bond pricing errors as in Gürkaynak, Sack, and Wright (2007). We use German zero-coupon yields for maturities between

Figure 4: ECB SMP weekly and cumulative purchases as reported on its balance sheet

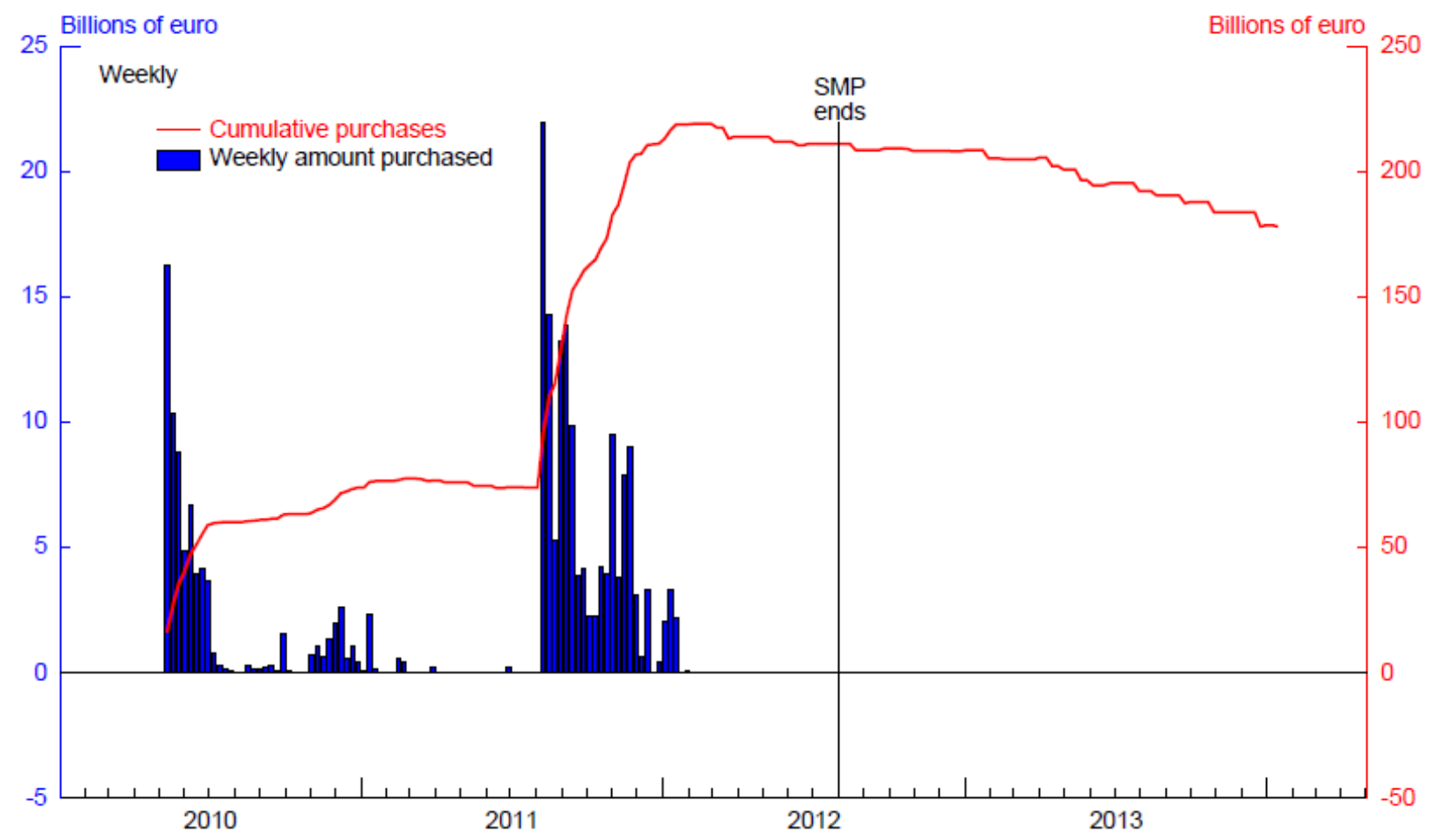

3-months and 10-years as our risk-free interest rates. We construct the latter using the SvenssonNelson-Siegel parameters that we obtained from the Bundesbank. ${ }^{8}$

The ECB reports its SMP purchases on its balance sheet as an aggregate of all the week's buying (see Figure 4). ${ }^{9}$ An important limitation of this data is that it does not disclose on which day the purchases were made, which country's bonds were acquired, or what maturities were selected. No bond-level data whatsoever is disclosed. However, we are not wholly in the dark. Based on information from investment banks, some of which are significant counterparties to the ECB, we are able to assert with some confidence that SMPI focused on Greek, Irish, and Portuguese debt (see Figure 5 for our estimated breakdown of purchases by country). The second SMP focused on Italian and Spanish debt, though we believe some Portuguese debt was also purchased. By assuming that the ECB bought in proportion to each nation's bond market

\footnotetext{
${ }^{8}$ These are available on http://www.bundesbank.de/statistik/statistik zeitreihen.en.php.

${ }^{9}$ http://www.ecb.int/press/pr/wfs/2013/html/index.en.html
} 
size - an assumption collaborated by market signals and observations from the trading desks of market contacts - and adjusting according to differential market pressures week-to-week, we were able to estimate the percent of each country's outstanding sovereign debt that the ECB purchased for both SMP programs (see Table 1).

Figure 5: Estimated country-specific breakdown of ECB SMP weekly purchases and cumulative sum of those purchases as a percent of that country's outstanding debt

Ireland

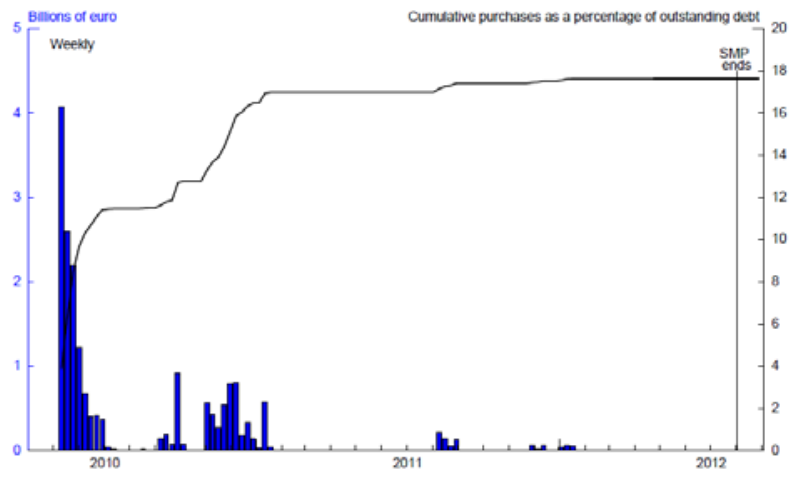

\section{Portugal}

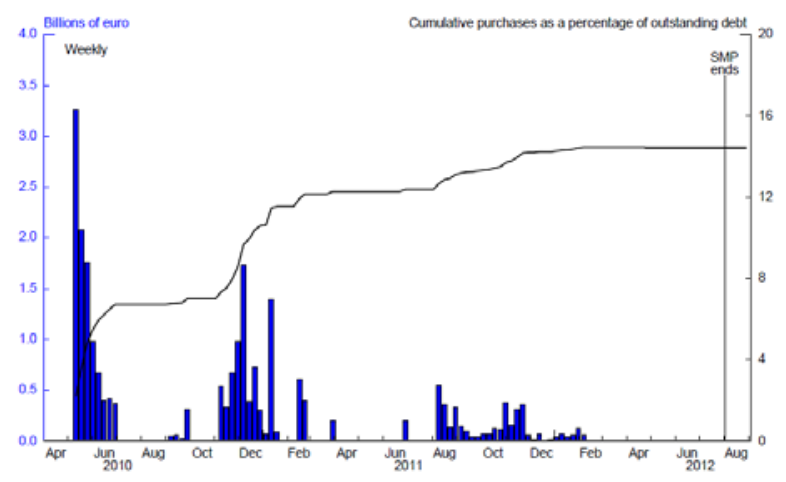

Greece

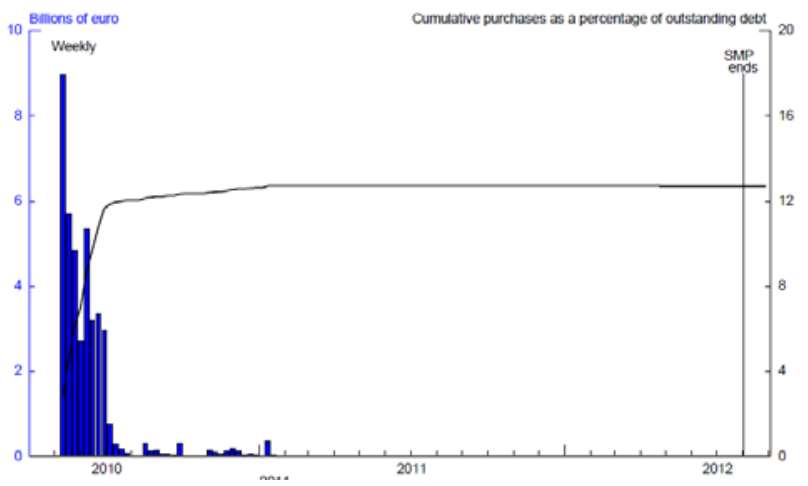

Spain

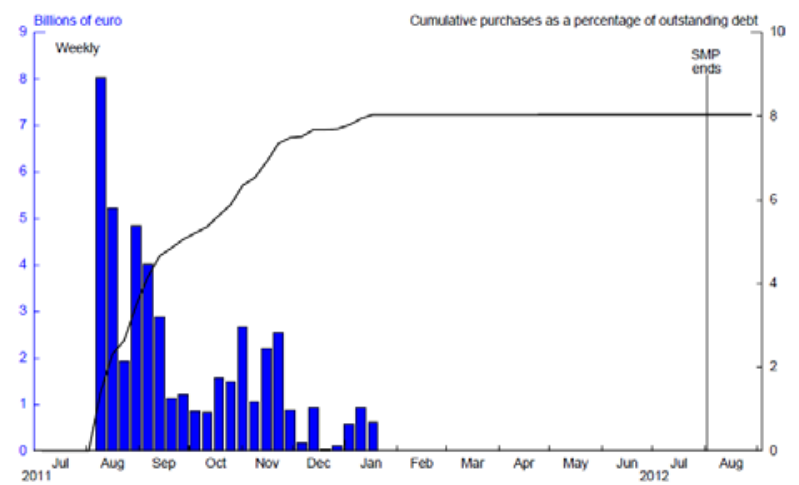

\section{Italy}

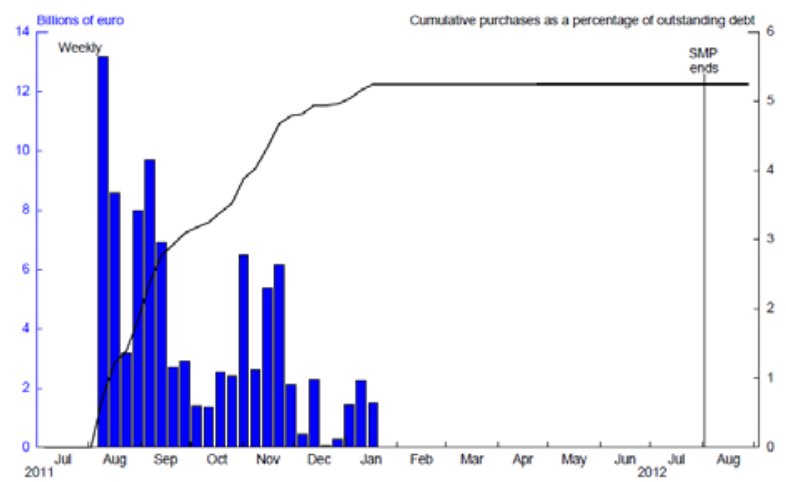

Note: Country breakdowns of SMP purchases are based on financial media reports and market contact information and the assumption that the ECB bought in proportion to the amount of each nation's outstanding debt. 
The Greek debt restructuring in March 2012 (see Figure 6) was a valuable additional source of information on SMP purchases, which confirmed our breakdown of SMP purchases. Greece’s debt restructuring was the largest of all time, entailing the restructuring of $€ 206$ billion of debt held by private-sector creditors. Closure of the deal was a precondition for a second EU/IMF loan deal worth $€ 130$ billion, which in turn prevented Greece from defaulting on $€ 14$ billion of debt falling due March 20. The debt restructuring obliged private-sector creditors to accept large losses on their holdings worth up to $70 \%$ in face-value terms.

One sticking point in the negotiations to secure private-sector participation in Greece's second bailout package was whether the ECB's holdings of Greek sovereign debt would be subject to haircuts. The ECB's position was that its bond holdings should be treated as senior debt and not subjected to haircuts, as they believed this would amount to monetary financing of government spending, which is expressly forbidden by European treaties. In the end, the ECB exchanged its Greek public debt holdings, some €40-50 billion worth, for new Greek bonds at par value, immune to the restructuring legislation passed by the Greek parliament. In return, the ECB agreed to put the profits from its Greek bond holdings, which it bought at below par value, towards the Greek bailout.

\section{Table 1: Estimated country allocations of the ECB's SMP holdings}

\begin{tabular}{lcc}
\hline & $\begin{array}{c}\text { Amount } \\
\text { Purchased } \\
\text { (Billions of euro) }\end{array}$ & $\begin{array}{c}\text { Out of } \\
\text { Outstanding Debt } \\
\text { (Percent) }\end{array}$ \\
\hline Total & $\mathbf{2 2 3 . 2}$ & $\mathbf{7 . 3 \%}$ \\
\hline Greece & 40.8 & $14.5 \%$ \\
Portugal & 22.9 & $13.4 \%$ \\
Ireland & 19.0 & $13.2 \%$ \\
Spain & 46.7 & $7.5 \%$ \\
Italy & 93.8 & $5.2 \%$ \\
\hline
\end{tabular}

Note: Outstanding debt is defined as debt issued by country as of February 10, 2012 - the last day of reported ECB purchases under the SMP.

The agreement revealed information on the maturity structure of ECB holdings of Greek debt. We compare the total amount outstanding of all Greek bonds, by residual maturity profile, to the residual maturity profile of the bonds issued directly to the ECB as part of the debt exchange. Data for this comparison comes from Bloomberg and Thomson Reuters. We find that 
the ECB purchased Greek bonds over a wide range of maturities, exhibiting a slight preference for bonds in the 3-to-5-year buckets. Furthermore, our estimates of the cumulative SMP holdings of Greek debt are, at approximately $€ 41$ billion, or $11 \%$ of total debt outstanding, reasonably close to the $€ 48$ billion total amount outstanding for the bond series exchanged directly with the ECB. Lacking further data on the maturity structure of ECB purchases, we focus our analysis of the SMP's effect on yields at the 5-year maturity for all country-specific securities in our study.

\section{Figure 6: Maturity profile of the ECB's Greek bond purchases}

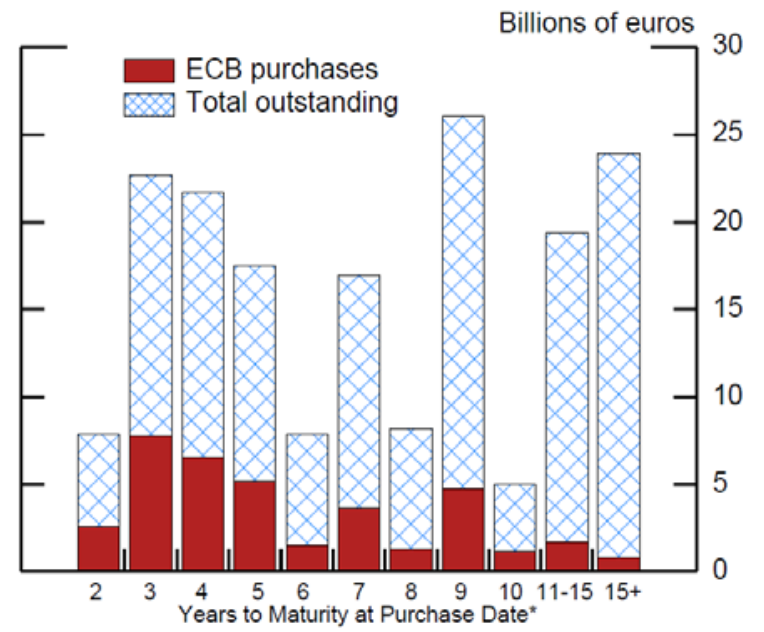

Note: Years to maturity calculated using residual maturity as of February 15, 2012 and an estimated average purchase date of June 2010.

\section{Description of Program and Conditions that Led to Intervention}

The ECB does not have a mandate to make direct purchases of its member country's sovereign debt on the primary market. However, from late 2009, there were few meaningful conventional monetary policy actions left to take amid deteriorating economic and financial conditions in Europe. Investors were ever more reluctant to lend to Greece, Ireland and, to a lesser extent, Portugal because of their high levels of debt, fiscal deficits, and current account deficits and accompanying sovereign ratings downgrades.

We observe the conditions that prompted the first SMP in European economic indicators. Greek, Portuguese, and Irish sovereign debt yields rose dramatically while yields in the core decreased in response to flight-to-quality flows, widening the funding spreads of all maturities of sovereign bond over the comparable sovereign debt of Germany (see the first panel of Figure 3). The premiums on credit default swaps on that debt, a form of insurance against investor loss 
given a default event, increased over the same period. The VSTOXX stock-implied volatility index rose precipitously at the end of April, reflecting sharply falling equities as it became apparent that Greece would no longer be able to service its sovereign debt without external assistance. In the macroeconomy in the first quarter of 2010, euro-area GDP contracted, investment and industrial production fell, the business climate index and economic sentiment indicators reached record lows, and the unemployment rate rose while both core and headline CPI fell below the ECB's target ceiling of two percent.

An overview of the events in the days leading up to the inauguration of the SMP gives a sense of the swift deterioration of the European situation. On April 22, 2010, Eurostat announces Greek’s 2009 budget deficit was larger than the 12.7 percent of GDP it had announced in November, which was itself twice the previously published figure. On April 27, the ratings agency Standard \& Poor's downgrades Greek (to junk) and Portuguese sovereign credit ratings with a negative outlook. On May 2, Greece finalizes its first bailout package with the EU and the IMF. On May 5, three people die when a bank is set on fire in Athens as a twoday, nationwide austerity strike devolves into violence. On May 9, the EU establishes a temporary bail-out mechanism, the European Financial Stability Facility (EFSF). The next day, May 10, the ECB announces the SMP and makes its first purchases.

To look at a financial stress in aggregate, we construct a financial stress measure for the euro area and each individual country through principal component analysis on a variety of financial market health indicators, including information from equities (return, volatility, correlation and bid-ask spreads), sovereign bond yields, credit default swaps, LIBOR-OIS spreads and corporate AAA-BBB bond spreads (see Figure 7). We then extract the first principal component of these eight series. This factor is the one linear combination of all series that explains as much of their joint variance as possible. To make the stress indexes available for cross-country comparisons, we normalize each by their maximum increase after the Bankruptcy of Lehman Brothers on September 15, 2008. Thus we could say that the French, Italian and Spanish response to the initial Greek financial stress was equivalent to 1 index shock while the response of Germany was around $1 / 2$ of an index shock.

The ECB interpreted market movements captured in these market indicators and our stress measure as signs that the sovereign debt market had become dysfunctional and illiquid. Indeed the bid-ask spread on 5-year sovereign debt for all countries, a common proxy for 
liquidity conditions, rose with yields. It responded through further monetary easing and by announcing the first SMP on May 10, 2010.

Figure 7: Euro-Area stress measures

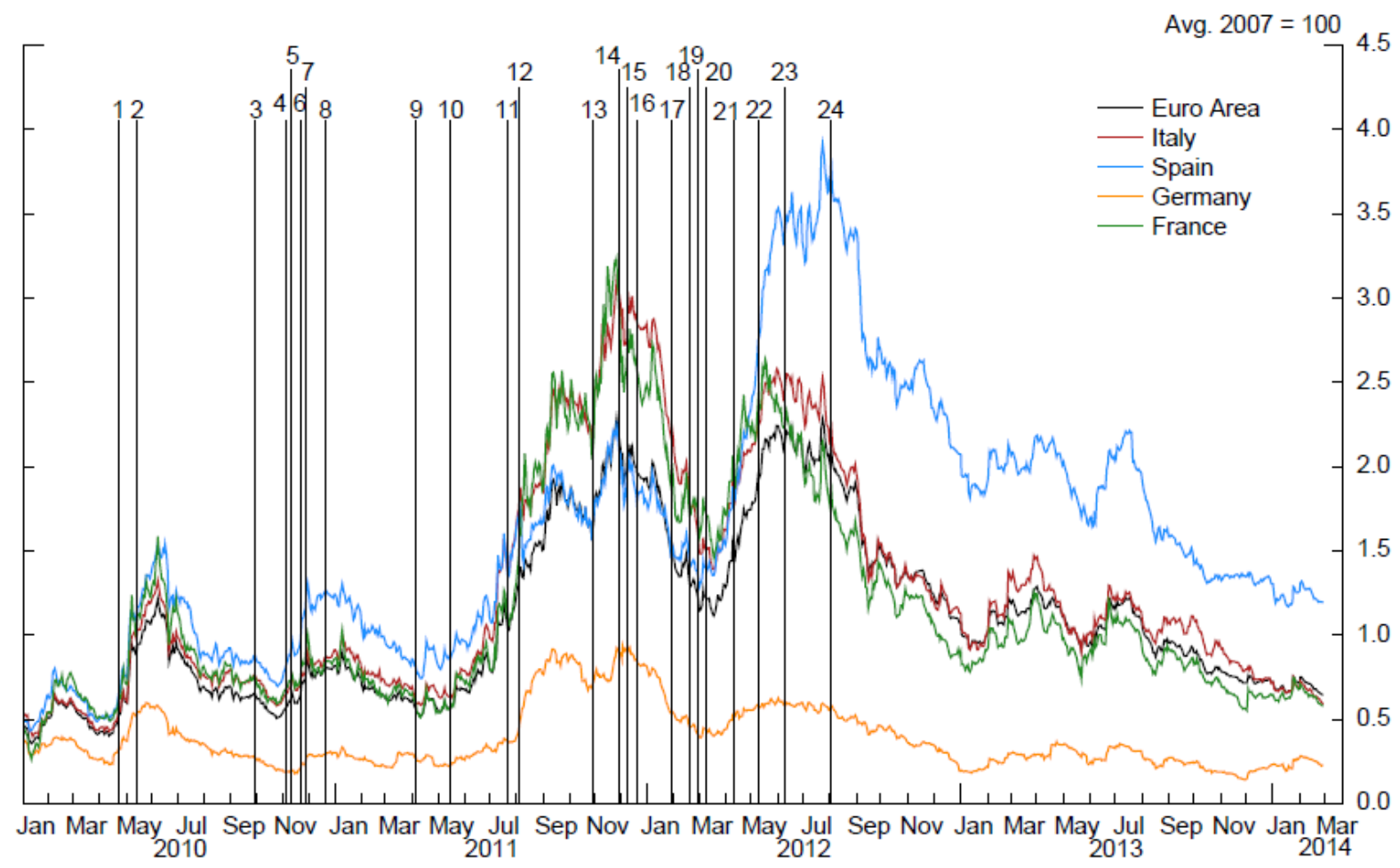

Vertical lines denote: 1.Greek 2009 deficit revised up; 2. Announcement of SMP; 3. Ireland's deficit rises steeply as supports banking sector; 4. Portugal loses market funding; 5. LCH.Clearnet increases Irish debt margin; 6. Ireland coalition government junior partner unexpectedly calls for elections; 7. Irish aid package; 8. Ireland recapitalizes major banks and subordinated debt holders take haircut; Spanish regions' finances revealed; 9. Fitch and Moody’s downgrade Portuguese debt to junk; 10. Portugal aid package; Greece may restructure its debt; 11. EU summit (second Greek aid package); 12. Expansion of SMP; 13. EU summit: Greek PM calls surprise referendum on second bailout; 14. Fed and ECB swap line arrangement expands; 15. ECB meeting: additional easing measures (LTRO); 16. First LTRO; 17. EU summit ( fiscal compact); 18. Second Greek aid package; 19. Second, three-year LTRO; 20. Greece achieves quorum of private bondholders to restructure its debt; 21. Greek PM steps down; 22. Greece fails to form a coalition government; Spain nationalizes Bankia; 23 EU Spanish bank rescue package; and 24. Announcement of the OMT and official termination of the SMP.

The SMP's form was strongly influenced by the political realities of the euro area. The ECB designed the program around its inflation mandate and its prohibition against direct sovereign support. It purchased bonds from the secondary market and all purchases were sterilized so they would not affect inflation expectations, even though this decision likely lessened the impact of the SMP on yields. The start and end of the SMP phases also seem to be related to political pressure on the ECB both to intervene at times of high market stress on the 
euro zone and to stop purchases once those pressures abated and the moral hazard issue again came to the fore of policy maker's concerns.

Every Tuesday the ECB published the aggregate amount purchased over the preceding business week on its balance sheet. ${ }^{10}$ Accordingly, the first ECB bond secondary market purchases were published on the ECB balance sheet on Tuesday, May 18, 2010. Peripheral bonds dropped sharply in response to the initial three weeks of purchases, which, at $€ 16, € 10$, and $€ 9$ billion respectively, together account for approximately $10 \%$ of all cumulative SMPI purchases (see Figure 4). Subsequent purchases varied from $€ 1$ to $€ 5$ billion. The first phase of the program continued for 64 weeks from the week it was announced at an average pace of $€ 2$ billion euro per week with 6 weeks with no purchase. The ECB bought a total of $€ 80$ billion in assets in the first phase of the SMP.

Small purchases continued during the relative calm of 2011 through July. At that point, Greece deteriorated to the point where it was forced to request a bailout. Euro area sovereign bond spreads rapidly widened again. This time, however, the much larger European economies of Italy and Spain came into question. Spanish stress in particular increased two-fold from its value September, 2008 - in the midst of the market turmoil surrounding the Lehman Brothers collapse (see Figure 7).

In response, the ECB resumed buying government bonds after a four-month break and announced new longer-term funding for liquidity-starved banks. The second phase of the SMP, from the announcement on August 12, 2011 that the program would be reactivated, was more aggressive in response to the perceived contagion to the systemically important economies of Italy and Spain. We estimate that the ECB no longer purchased Greek debt but focused on Italy and Spain, while continuing to buy some Portuguese and Irish sovereign bonds. Again, the initial purchases were the largest and had a strong effect on asset prices (see Figure 4 and Figures 8-11). The first five weeks of the 30 week program represented $50 \%$ of the cumulative $€ 145$ billion assets the ECB purchased through February 2012.

\footnotetext{
${ }^{10}$ http://www.ecb.int/press/pr/wfs/2013/html/index.en.html.
} 
Figure 8: Initial reaction to ECB asset-purchase program announcements by countries included in the program

SMPI: May 10, 2010

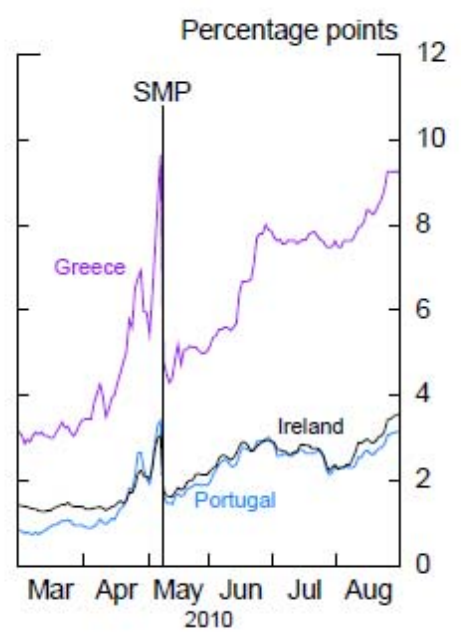

SMPII: Aug. 7, 2011

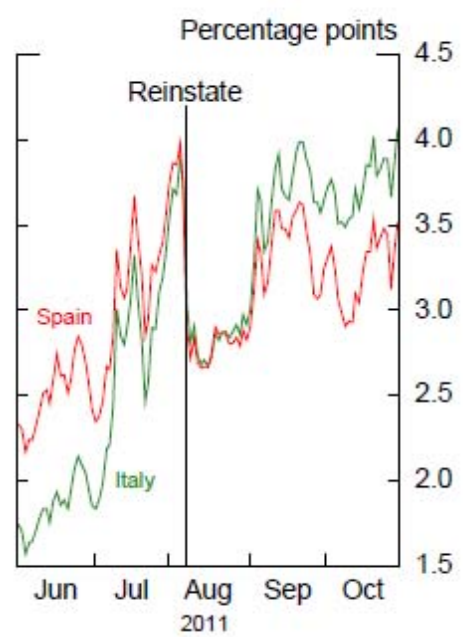

OMT: Aug. 2, 2012

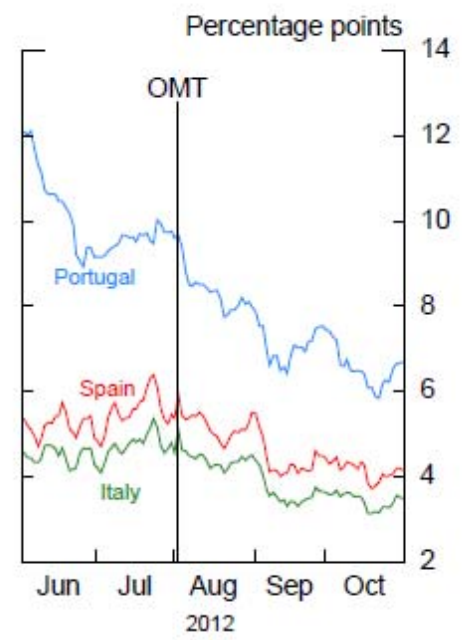

Note: Data are ten-year sovereign spreads over ten-year German bunds.

\section{IVa. The Size of the Announcement Effect}

There is no doubt that the announcement effect was large and sustained, both for the initiation of the SMP in May 2010 and the announcement of its reinstatement in August 2011 (see Figures 8-9). In this section, we establish this effect. Since there are only two announcement dates, our analysis takes the form of a narrative rather than robust econometrics.

Observe in panels one and two of Figure 8 that in sovereign markets, the initial response to the initiation of the SMP is a decline in the yields of purchased countries over their German Bund equivalents. This effect is large and, though yields continue their upward trajectory, the levels remain subdued for some time after the initiation of purchases. In contrast, in European countries whose bonds were not purchased by the SMP, of which a few are portrayed in Figure 9, do not exhibit this strong, sustained response. Thus, while the initial narrowing of spreads may be attributed to an announcement effect as investors formed expectations over the total size of purchases going forward, there is anecdotal evidence that there is an effect from purchase themselves.

However, after initial declines following both the announcement of the SMP and its reinstatement, peripheral bond yields continue their inexorable climb towards danger levels. 
Traders said they were not convinced bond-buying would be effective in stopping contagion to the euro area's third and fourth largest economies. The lack of a perceptible long-term effect may also be due to the small relative amount of assets purchased with the SMP - over the entire period the SMP was active, the ECB purchased approximately 8\% of peripheral sovereign debt outstanding. Figure 9: Initial reaction of 5-year sovereign yields to SMPI announcement in countries
whose bonds were not purchased by the SMP

\section{Germany}

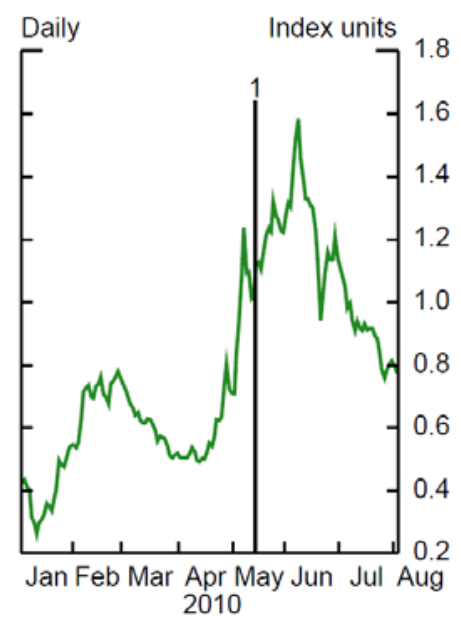

Italy

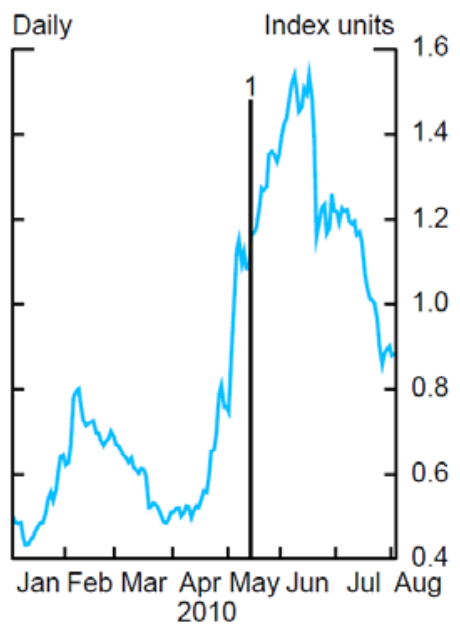

France

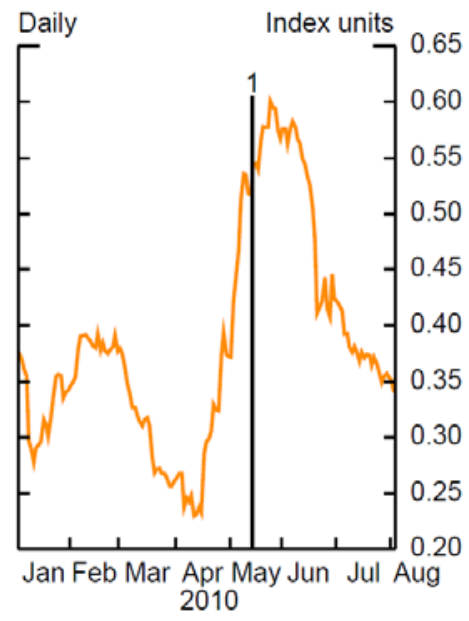

Spain

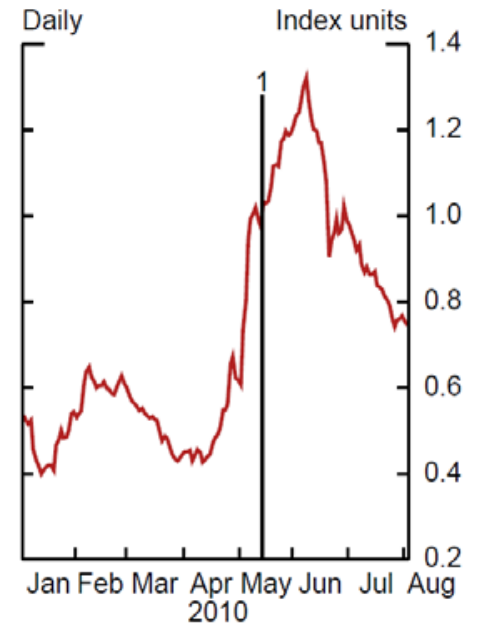

Note: Data are 5-year sovereign spreads over 5-year German bund (shown in levels in panel 1). The vertical lines denote the announcement of the SMP on May 10, 2010. Zero is the level of financial stress during 2007.

We also note that the announcement on August 2, 2011, of the OMT, portrayed in panel 3 of Figure 8, is also followed by a decline in yields of similar magnitude. As the OMT has never been activated to date, we assert that the entire drop in yields can be attributed to an 
announcement effect. In all three instances, the signal that the ECB was going to take actions to address the looming crisis clearly calmed markets, at least temporarily.

IVb. Mistaken beliefs: an example of a pure announcement effect

We suspect much of the observed effects attributed to the SMP program are due to the signaling power of ECB interventions; especially the effects observable from the initial purchases of both the SMP itself in May 2010 and its reactivation in August 2011. Two cases where the market reacted as if the ECB had purchased bonds with the SMP, when it in fact had not done so, anecdotally support this notion (see Figure 10). On March 18, 2011, Reuters reported that Portuguese yields fell unexpectedly across the yield curve (approximately 31 basis points at the 5-year maturity and about 22 basis points at the 10-year) and that traders attributed the move to purchases by the ECB in the secondary market. ${ }^{11}$ They report that the ECB had been asking for quotes at the short end of the yield curve. The article did note that the ECB had not been active during recent weeks “despite market speculation.” But ten days later, during which time Portuguese yields had risen again and precipitously, the Financial Times on March 28, 2011 reiterated the assertion that purchases had been made on March 18, because the ECB had "settled deals worth $€ 432$ million" the week before. ${ }^{12}$ "The ECB's announcement on Monday appeared to confirm traders' reports it had bought Portuguese bonds on March 18 in deals that would have been settled last week.” However, as reported on the ECB's balance sheet, the ECB actually decreased its holdings of the securities purchased under its various programs by $€ 0.2$ billion as the result of maturing bonds under the SMP and the Covered Bond Purchase Programme. ${ }^{13}$

The second instance where markets reacted on a belief that the ECB had made SMP purchases when it had not was on August 4, 2011, just days before the ECB announced the active reinstatement of the SMP program on August 7, 2011. ${ }^{14}$ The confusion appears to have been caused by remarks made by the then-President of the ECB, Jean-Claude Trichet, at a press

\footnotetext{
11 “Portuguese/German bond yield spread tightens” March 18, 2011 8:26AM EDT; Reuters http://www.reuters.com/article/2011/03/18/markets-bonds-spreads-idUSLDE72H19I20110318

12 "ECB settles €432 m in government bond deals" March 28, 2011; ft.com http://global.factiva.com/redir/default.aspx?P=sa\&an=FTCMA00020110328e73s002pa\&cat=a\&ep=ASE

${ }^{13} \mathrm{http} / / / \mathrm{www}$. ecb.europa.eu/press/pr/wfs/2011/html/fs110322.en.html

14 "Italy, Spain Bond Yields Fall, Still Above 6\%" April 5, 2011 2:16PM EST; The Wall Street Journal http://global.factiva.com/redir/default.aspx?P=sa\&an=WSJO000020110805e785003e9\&cat=a\&ep=ASE
} 
conference after a meeting of the ECB's Governing Council. ${ }^{15}$ "I never said that the SMP had been interrupted," Trichet said in reply to a question on the ECB's SMP. Trichet then said: "I wouldn't be surprised if by end of this press conference something happens," and when asked if he could confirm that the ECB was at that moment in the market for southern European bonds, said: "I commented in advance it seems to me." Directly after the press conference, many news outlets reported ECB purchases of Portuguese and Irish debt, citing traders as their sources. ${ }^{16}$

\section{Figure 10: Behavior of Portuguese 10-year yields around March 18, 2011}
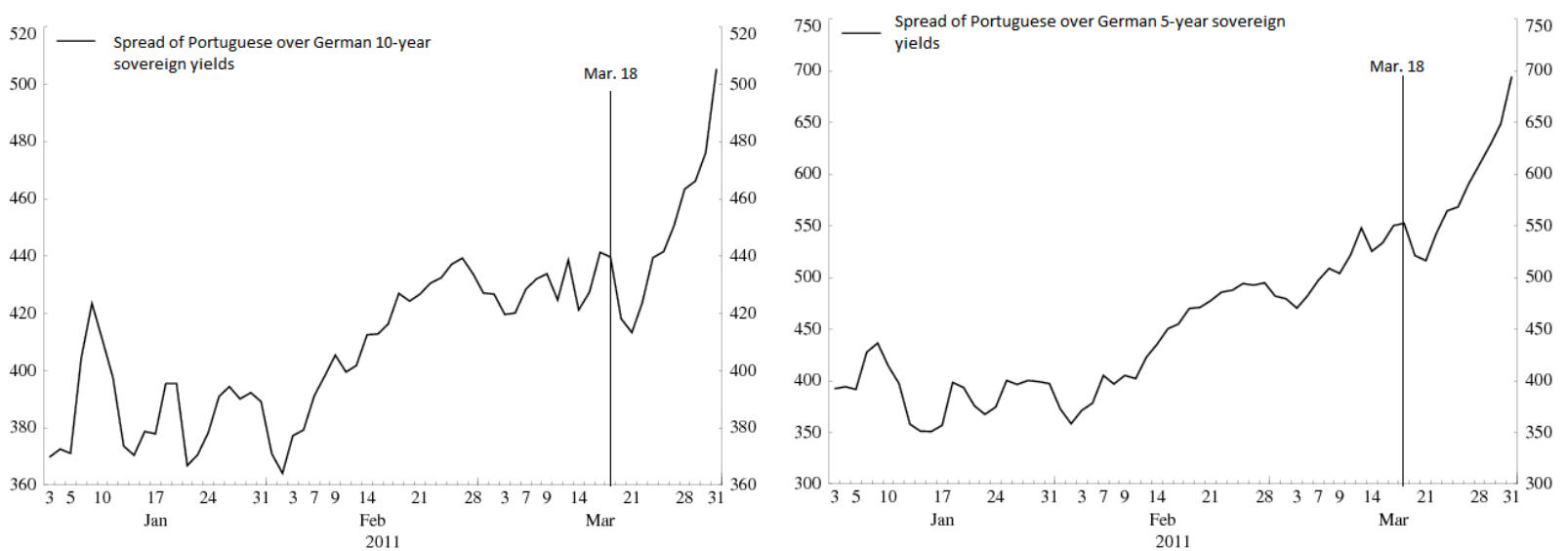

Yet, as in the March 2011 example, no purchases were recorded for the week ending August 5 on the ECB's consolidated financial statement of the Eurosystem as of the following Tuesday, August 9, when the ECB would report purchases on its balance sheet had it made any. In fact, as in the previous case, the holdings of securities purchased by the SMP actually decreased, this time by $€ 0.1$ billion. ${ }^{17}$ Another confounding factor is that there were reports from the same traders that the Bank of Italy and the Bank of Spain were buying debt in their respective markets in the days leading up to the announcement of the reinstatement of the SMP on August 7, which may have been the information to which the questioner at the press conference was responding.

\footnotetext{
15 https://www.ecb.europa.eu/press/pressconf/2011/html/is110804.en.html

${ }^{16}$ E.g., "ECB Bond Purchases Are High-Stakes Gamble” August 5, 2011; The Wall Street Journal http://global.factiva.com/redir/default.aspx?P=sa\&an=WSJO000020110805e785000p8\&cat=a\&ep=ASE

"Italy, Spain Bonds Firm As ECB Buys Portugal, Ireland” August 4, 2011; Dow Jones Newswires. http://global.factiva.com/redir/default.aspx?P=sa\&an=DJI0000020110805e785001pk\&cat=a\&ep=ASE "ECB to offer banks longer funds, seen buying bonds" August 4, 2011; Reuters News. http://global.factiva.com/redir/default.aspx?P=sa\&an=LBA0000020110807e784000ec\&cat=a\&ep=ASE ${ }^{17}$ http://www.ecb.europa.eu/press/pr/wfs/2011/html/fs110809.en.html
} 


\section{Event study}

As is common in event studies, our initial analysis is in the form of butterfly charts, allowing us to visualize the behavior of yields, or other variables of interest, across numerous purchases dates. Because levels of the variables evolve substantially over the study period, we index each data series to a value of 100 on the Friday of the intervention week for each SMP purchase. This allows us to isolate the trajectory of yields before and after the ECB's various interventions. We typically look at the period 10 weeks before and after purchase. In this way, we are able to examine yields well beyond the period where the ECB's actions may be having a substantial influence on market liquidity.

Because we have observations on so many purchase dates, it is not particularly useful to plot the yields before and after individual purchases for most of our analysis. To summarize the typical behavior across purchase events, we calculate the median value of yields at each week across the purchase observations to construct the median path of yields before and after purchase. Our results are not qualitatively different if means are constructed. We first break down the effect by country, using our purchase estimates. We include Ireland, Italy, Spain, Portugal, and Greece. Finally, the units in the figures are percentage point changes relative to the week of intervention. Therefore for each country, we plot the average median values across all intervention weeks.

We include for each country only those weeks where we believe the SMP purchased that country's debt that week. We compare this estimate to aggregate average movement in the country's yields around weeks with no purchases and to the movements of the German 5-year rate, which we take as a proxy for the risk-free-rate. Finally, we break purchases into quartiles based on the size of SMP purchases relative to the country’s outstanding debt.

Although we confirm these results with more rigorous econometric work below, these figures aptly illustrate our main result. Looking at the top left panel of Figure 11, yields in all four countries are rising rapidly in the weeks before the purchase. In large part, it is this rise in yields that triggers the ECB's intervention. As an aside, although the ECB claims to be operating only to restore market functioning, in practice, their proxy for poor market functioning appears to be an increase in yields. We almost never observe interventions on weeks when yields have been stable or declining. 
Figure 11: 5-year peripheral sovereign spreads and yields around purchase weeks

Median including announcements

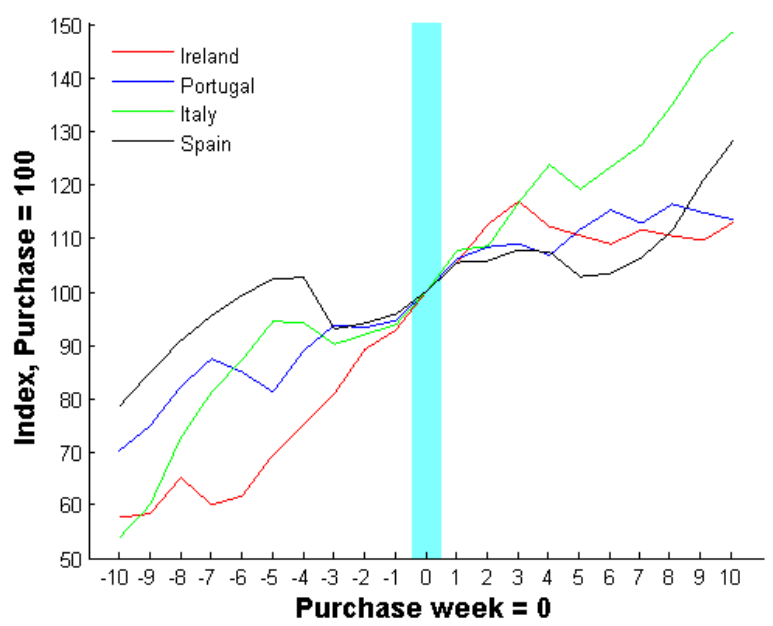

\section{Median excluding announcements}

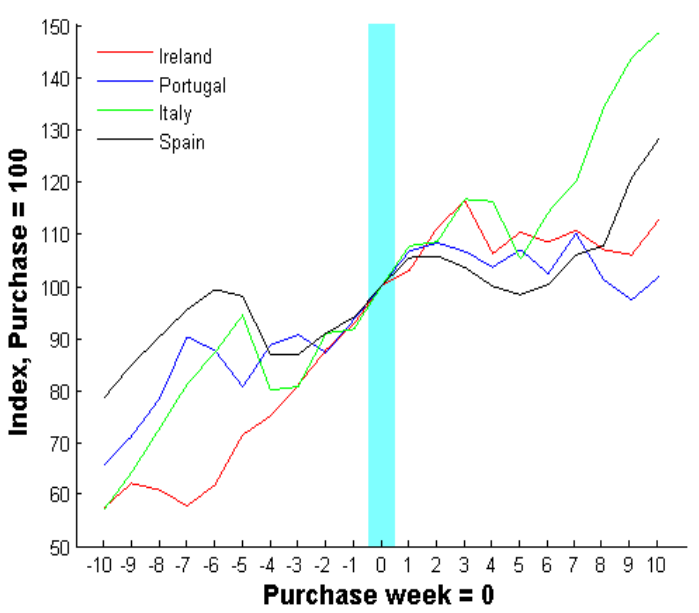

\section{German Yields}
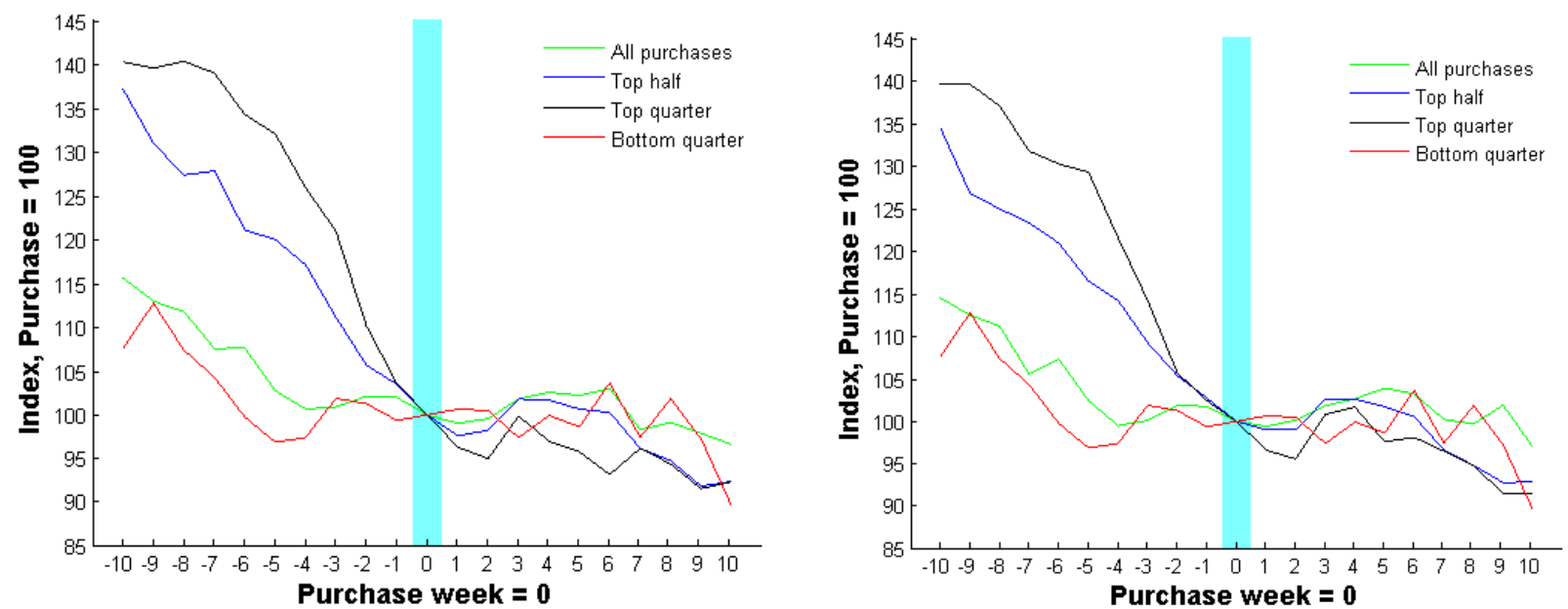

Note: Spread over comparable maturity German bonds. Data shown for top quartile of bond purchases over the period May 14, 2010 to February 10, 2012. Units in are percentage point changes relative to the purchase week.

Returning to the figure, in the first two to three weeks following the ECB's purchase, yields continue to rise unabated. We observe some stability in weeks 4 to 6 , a period well beyond what we would consider an immediate purchase response, especially since the respite is short-lived and yields rise again by the end of the window. Clearly adding the two announcement days to the figures would be expected to have little effect on the median value, the figure to the right shows the evolution of spreads excluding announcements. This differentiation will be much more important in the regression work below and is included here for completeness. 
Figure 12: Aggregated 5-year peripheral sovereign spreads around purchase weeks

Mean

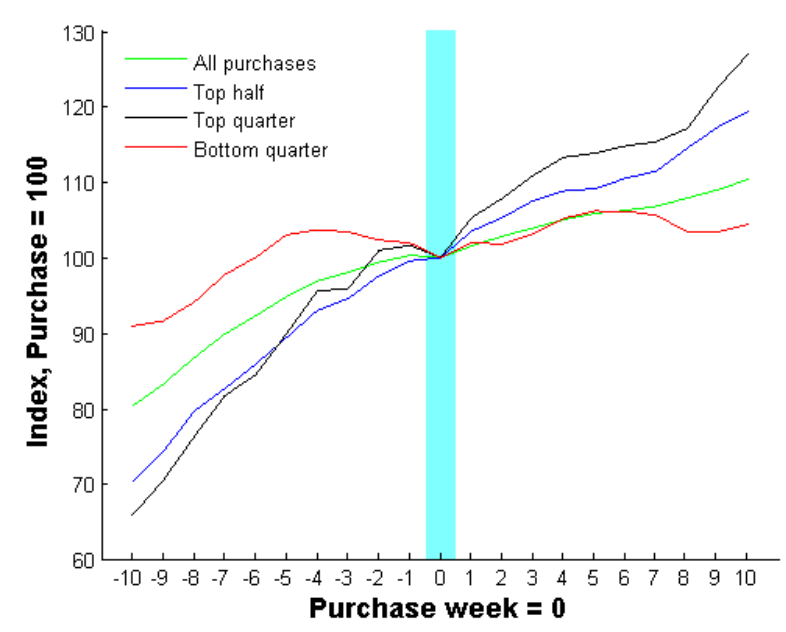

Median

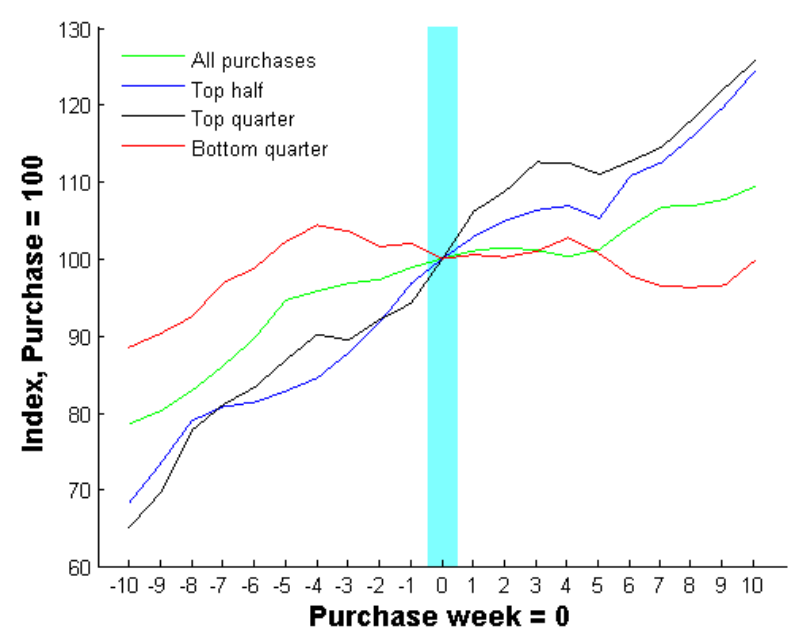

Mean ex. announcement days

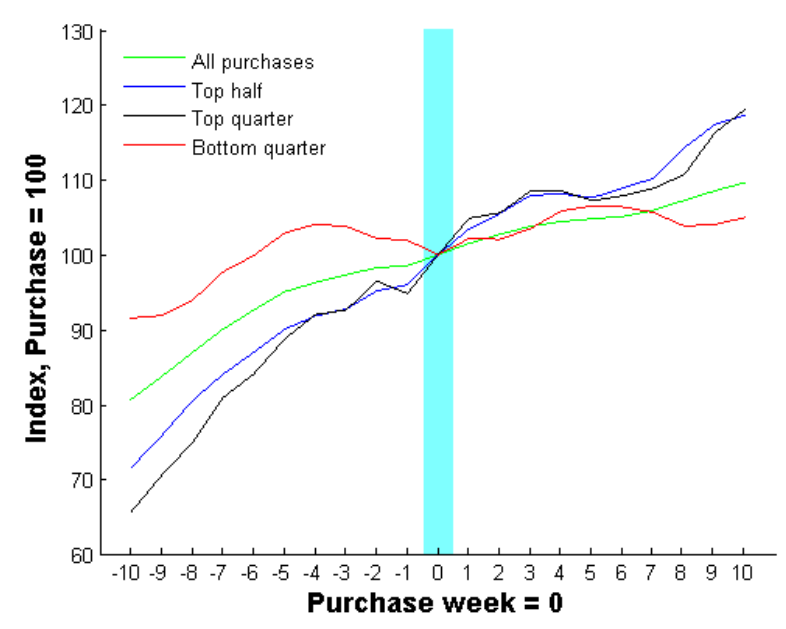

Median ex. Announcement days

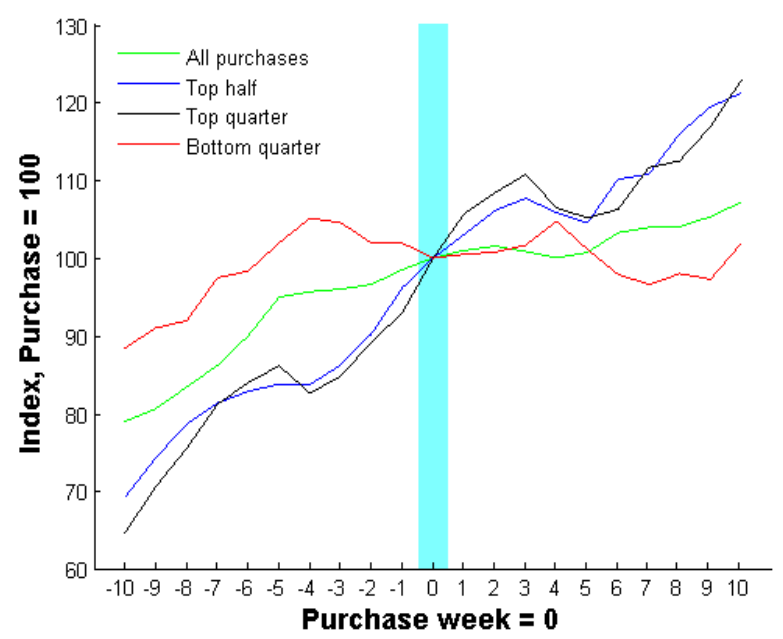

Note: Data shown over the period May 14, 2010 to February 10, 2012. Units in are percentage point changes relative to the purchase week.

Turning to the bottom panels, we show the evolution of German 5-year yields around the same purchase dates as in the first panel. The lines in the chart show the evolution of yields for all purchases, for purchases above median size, purchases in the top quarter, and purchase size in the bottom quarter. Importantly, the ECB sterilizes all SMP purchases, specifically to avoid changing the real interest rate or overall liquidity conditions in the euro area. These figures indicate that they are not quite successful in this lack of effect goal.

In the weeks before purchase, whether larger or small, German yields fall, likely as a result of flight-to-safety pressures associated with the debt crisis itself. Subsequent to the purchase, 
yields stabilize (on net German yields fell 98 basis points over the period as a whole). The result is, of course, the same whether or not the purchase announcements are included. If the purchases had in any way stabilized the evolution of yields, we would be tempted to interpret this finding as evidence of ECB efficacy - the ECB buys peripheral bonds, risk is diminished and flight-to-safety flows wane. Since spreads do not stabilize, we do not believe this explanation. ${ }^{18}$

Turning to Figure 12, the top quartile of aggregate purchases rises steeply on average in the weeks leading up to a purchase event, reflecting that the largest purchases were made at the beginning of each SMP and in response to the steepest increase in yields. Immediately after the purchase week, the average path of yields continues to increase, but at a lower trajectory. On average between 5 and 6 weeks out, the path of yields declines below those of non-purchase weeks; which weeks were financially quieter by their very selection. The top half of the purchases behave in much the same way, though the trends are smoothed since the sample includes other purchase dates than the program initiation purchases. This smoother curve shows more clearly the shift down in the trend of average yields both relative to their former trajectory and in relation to the average non-purchase week trend.

The bottom quartile of purchases displays the same movements. This line is interesting as these purchases were made in periods of less market stress, relative to the timing of the larger purchases, removing some of the noise of concurrent fiscal programs and counteracting market movements. Thus the green line may show more of an isolated SMP purchase effect than the larger purchases did. It is the only purchase line where there is a marked average decrease of yields within the first week.

Perhaps the lagged effect observed in the other lines can be understood not as a lack of SMP transmission to yields but as evidence of the strong upward trend in peripheral bond yields we observe at the time of the largest purchases. For example, on the likely purchase day of November 2, 2011(see Figure 13), there was an immediate intraweek lowering of yields but by the end of the week yields were higher in absolute terms than they had been at the start of the week. This event study gives us an indication that the effect of the SMP, even on weeks where the overall trend was for yields of all countries to increase regardless of whether their debt was

\footnotetext{
18 A complicating factor is the Swiss National Bank. The same flight-to-safety flows putting downwards pressure on bund yields also places appreciation pressure on the franc. Over this period, the SNB was actively intervening to prevent franc appreciation, typically by purchasing German bonds. During periods of heightened pressure (as measured by the rise in spreads), the SNB would tend to intervene.
} 
purchased by the ECB, was still to moderate the rate at which yields were increasing. And during times of less market stress the ECB was able to buy less bonds whenever they noticed yields rising, with a more or less immediate pass-through to lower yields.

Figure 13: Example where the SMP's intraweek response was masked

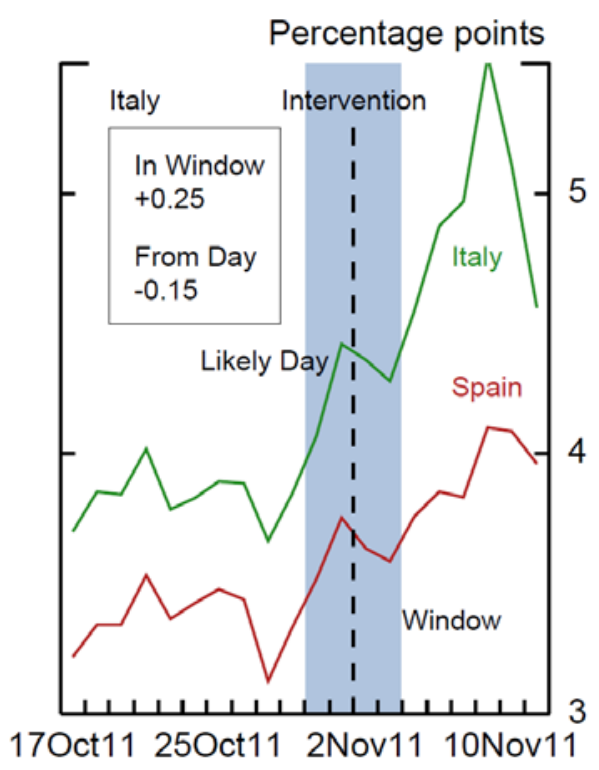

To test for the robustness of these trends we see in the average effects of SMP purchases on 5-year sovereign bond yields, we also used our event-study methodology to examine the average effects of SMP purchases on spreads over 5-year German bunds and on the 5-year probability of default from CDS (see Figure 14). We again observe that, on average, the rate of change deviates notably from its trend following an SMP purchase of any size in contrast to weeks where no SMP purchases occurred. Furthermore, larger ECB bond purchases coincided, on average, with larger changes in the underlying variables. However, when focusing on the average effect of SMP purchases on the 5-year probability of default from CDS, the average decrease after a purchase relative to non-purchase weeks is much more pronounced and there is less of a lag before rates decline, even in the largest purchases. Perhaps this is due to the positive signaling effect of a purchase to investors that the ECB is willing to take action to combat rising peripheral borrowing costs, which may affect the market's perception on the likelihood of a default more immediately than its perception of the likelihood of yields continuing to rise. 
Figure 14: Aggregated 5-year probability of default from CDS around purchase weeks

Mean

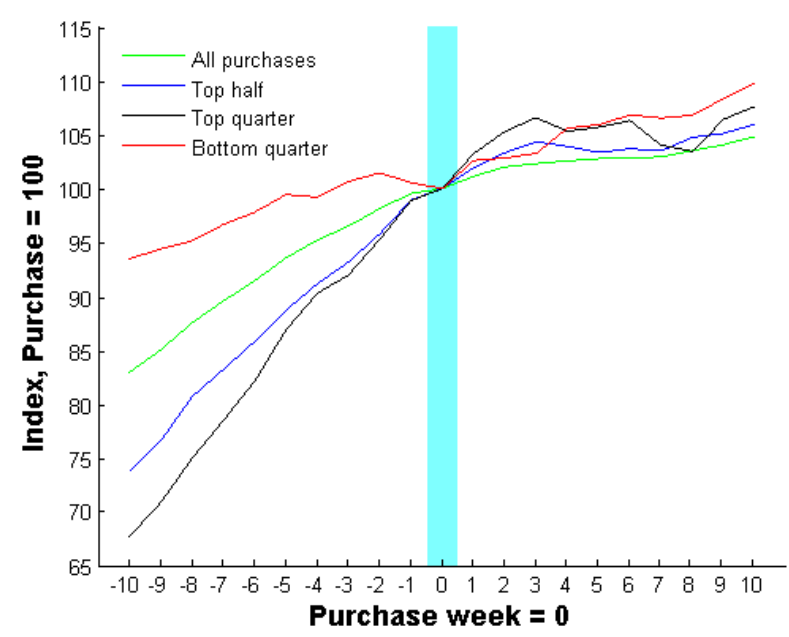

\section{Median}

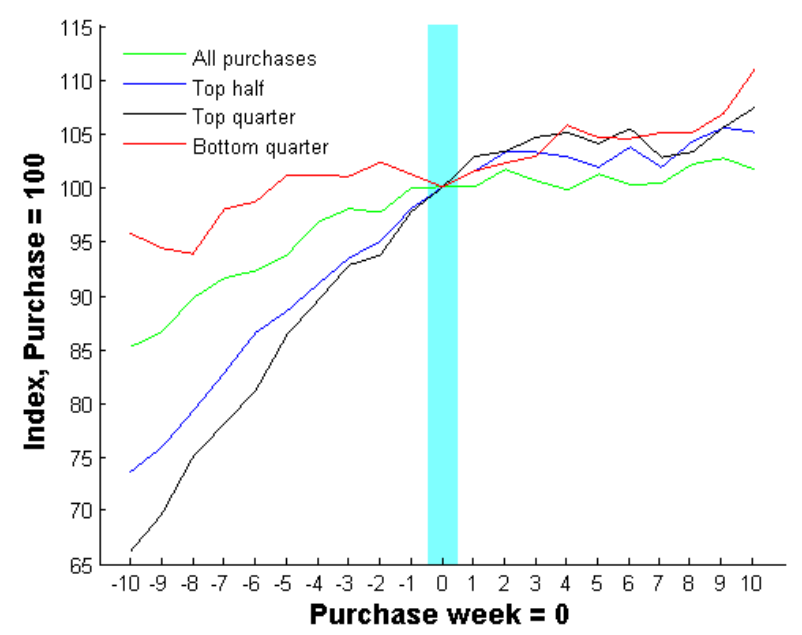

Mean ex. announcement days

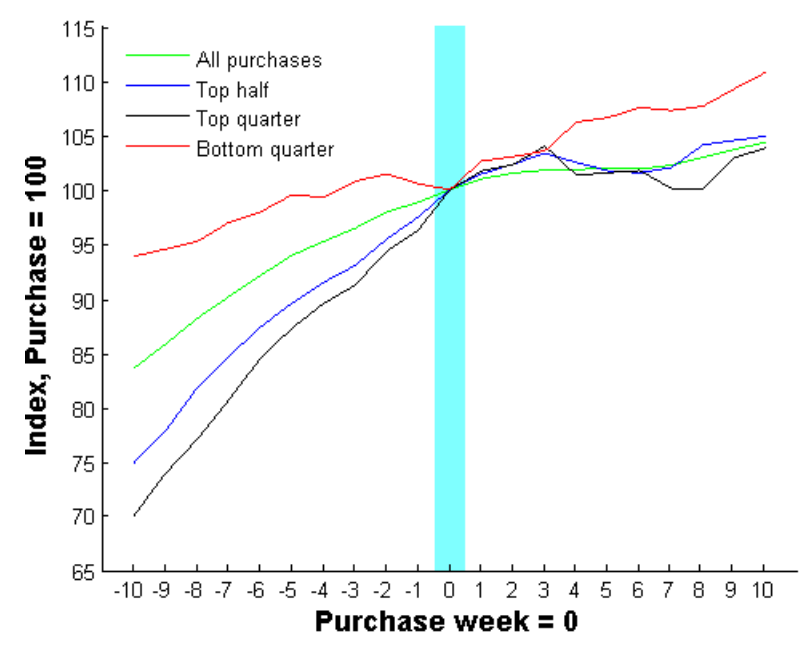

Median ex. Announcement days

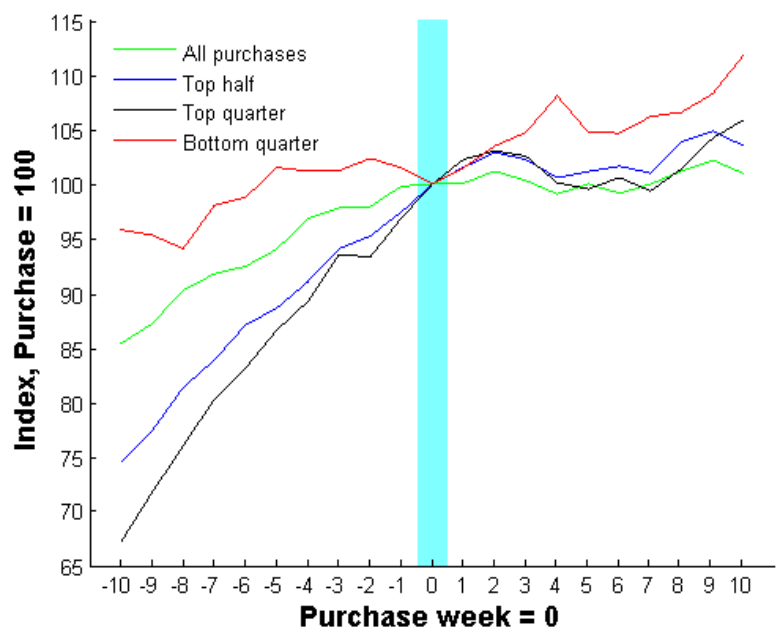

Note: Data shown over the period May 14, 2010 to February 10, 2012. Units in are percentage point changes relative to the purchase week.

We can compare these results to the average movement of the German rate at the same time (see Figure11). The ECB did not buy any German bonds in either SMP, but the 5-year bund rates did respond to the same market pressures. German yields fell steadily over the European Debt Crisis period (see the second panel of Figure 3) as investors searched for safe investments. Looking at the average behavior of 5-year German yields around purchase dates, we see a consistent decline in yields before purchases and then an on average moderation or even a slight increase in yields after purchases. However, on weeks with no purchases, the average behavior of German bunds is to continue to decrease. 
With the low frequency of data and the strong assumptions we must make about ECB purchase behavior, these event studies are hardly definitive evidence of the effectiveness or ineffectiveness of the SMP purchases. Also, there is significant endogeneity as the crisis was enfolding during the entire period of purchases and there were concurrent fiscal programs in all the countries included. Furthermore, the ECB purchases do not appear to be random (see Figure 4). The ECB clearly intervened when yields were peaking and one would expect that yields would decrease at some point 10 weeks after a peak regardless of any intervention. We therefore turn to more robust econometrics in the next section to continue to investigate the efficacy of the SMP in lowering European debt levels.

\section{Regressions}

\section{VIa. Panel regressions}

Table 2 contains estimates of the relationship between the weekly movement of country sovereign yields and the European Central Bank's SMP purchases over the whole SMP period. We limit attention to Ireland, Italy, Portugal, and Spain to avoid the complications specific to the Greek debt restructuring that we discussed above. Estimation is by generalized least squares with country fixed effects. The dependent variable is the weekly average of daily percentagepoint changes in each purchase country's 5-year sovereign bond yield. It is commonly believed, and anecdotally confirmed by our breakdown of Greek issuances above, that the ECB bought country debt predominantly at the two- to 5- year maturities. We ran the same regressions with two-year sovereign yields with no significant change in results.

The independent variable of our base specification (column 1, Table 2) is our estimate of the ECB's weekly purchase for each country as a percent of that country's total outstanding debt each purchase week. The results are interpreted as the percentage point effect on the change in yields per percent of outstanding debt the ECB purchased. The independent variable for the second specification (column 2 of Table 2) is total weekly SMP purchases in billions of euros, as reported on the ECB's balance sheet on the Tuesday following every purchase week. The results are interpreted as the basis point change in yields per billion euros purchased by the ECB. We include the second specification to check that any results of the base specification are not due to our estimates of the breakdown of the SMP purchases by country. 
Table 2: Panel regressions; relationship between the ECB's SMP purchases and changes in 5-year sovereign bond yields for the whole SMP period, May 14, 2010 to Feb. 10, 2012.

\begin{tabular}{|c|c|c|}
\hline Weekly percentage point change & $\begin{array}{c}\text { (1) } \\
\text { Country-breakdown of } \\
\text { purchases (\% outstanding } \\
\text { debt) regressed on country } \\
\text { yields }\end{array}$ & $\begin{array}{l}\quad(2) \\
\text { Aggregate Purchases } \\
\text { (USD Bil.) regressed on } \\
\text { each country’s yields }\end{array}$ \\
\hline \multicolumn{3}{|l|}{$\underline{5-y e a r}$ sovereign yield } \\
\hline Constant & $\begin{array}{l}0.06^{* *} \\
(0.03)\end{array}$ & $\begin{array}{c}0.10^{* * *} \\
(0.03)\end{array}$ \\
\hline Country panel & $\begin{array}{c}-0.23^{* * *} \\
(0.07)\end{array}$ & \\
\hline Reported weekly purchases & & $\begin{array}{c}-0.03^{* * *} \\
(0.01)\end{array}$ \\
\hline R-Squared & $3 \%$ & $5 \%$ \\
\hline Regression standard error & 0.49 & 0.49 \\
\hline Observations & 368 & 368 \\
\hline
\end{tabular}

Note: Aggregated purchases are SMP purchases as reported by the ECB, in billions of euros, on the Tuesday following each purchase week. Country-level purchases are our estimates of the country breakdown of the ECB's SMP purchases based on market sources and news. *** indicates a p-value of 0.00 ; ** a p-value less than 0.05 ; and * a p-value between 0.05 and 0.1 .

We find a strong significant relationship between the country-specific purchases as a percent of outstanding country debt and the average change in yields. Specifically, we find that when the ECB purchases a percent of outstanding country debt, 5-year sovereign yields decreased by approximately 23 basis points. The relationship is also strongly statistically significant when the changes in 5-year sovereign yields are compared to the ECB's aggregate, reported purchases. However, the magnitude is small; we find an approximate decrease in 5-year sovereign yields of 3 basis points for every billion euros of outstanding debt the ECB acquires. Running the same regressions including Greece garnered nearly identical results.

Our event-study analysis above suggested a possible anecdotal case for an economically significant effect of the ECB's SMP purchases on peripheral yields and the cost of insuring against sovereign default. But while the regression results in Table 2 are highly significant and though the signs of the coefficients are in the expected direction, the magnitude of the coefficients are much too small to support a claim that the SMP lowered 5-year yields in a 
meaningful way. Furthermore, both regressions have small R-squared statistics and large regression standard errors, indicating that the majority of the variation in yields over the SMP period cannot be explained by SMP purchases alone.

A possible explanation is that, though all peripheral bond yields dropped sharply in response to the initiation of each of the SMP's two phases, yields continued to increase over the whole sample period. Thus, at a weekly frequency, the effects of the ECB's purchases may not be apparent. Simply regressing the weekly change in yields on the country-specific SMP purchase discounts the intraweek effects of the intervention by the overall upward trend in yields. For example, the highlighted intervention period in Figure 13 represents the week of Friday, November 4, 2011, where SMP purchases totaled €9.5 billion. Using information from market sources, we can pinpoint a likely day when the ECB made those purchases. Spanish and Italian yields did decrease noticeability during the intervention period, only to end the week higher than they began, largely due to the upward trend in yields across all countries in our sample. Thus the effect of the SMP is likely in lowering the trajectory of the increase in peripheral yields over the period, an effect that is hard to quantify. Another complicating factor is that the ECB tended to purchase significant amounts on the very weeks when market stress was unusually high, forcing EU leaders to also take market-calming actions. Furthermore, extraordinarily high run-ups in yields are more likely to mean-revert as they reach their peak.

We next run the same panel regressions separately for the two, quite distinct, phases of the SMP. Recall that we define the first phase of the SMP as the period from the announcement of the program on May 10, 2010 to July 1, 2011 - the Friday of the last purchase week before the second phase of the SMP began. We believe that the ECB only purchased Greek, Portuguese, and Irish debt over this period, but we again exclude Greece from the regression (if Greece is included, the results are robust but the standard errors are higher). We again examine the relationship between weekly changes in average 5-year sovereign yields and SMP purchases both in aggregate over the period and our country-specific estimates as a percentage of each country's outstanding debt. Columns one and three of Table 3 are our base specifications run over the entire period of the first phase of the SMP.

The results of the specification covering the first phase of the SMP (columns one and three of Table 3) are nearly identical to those obtained from the full-period regression. We estimate that for every percentage point of outstanding country debt purchased, yields decrease 
by approximately 27 basis points. And for every billion euros the ECB purchases, yields decrease by around 3 basis points. However, our measure of fit is much higher over this period and our regression standard errors lower. But all statistical effect vanishes once we exclude the first week of the SMP when the largest purchase amounts were combined with an announcement effect. Thus, running the same specifications over the period May 21, 2010 to July 1, 2011 (columns two and four of Table 3) we can see that the coefficients go from strong statistical significance to no discernable effect.

Table 3: Relationship between the ECB's purchases in the first phase of the SMP and changes in 5-year sovereign bond yields.

\begin{tabular}{|c|c|c|c|c|}
\hline Weekly percentage point change & $\begin{array}{l}\text { (1) } \\
\text { Country-breakdown } \\
\text { of purchases [\% } \\
\text { outstanding debt] } \\
\text { regressed on } \\
\text { country yields }\end{array}$ & $\begin{array}{l}\text { (2) } \\
\text { (1) without the } \\
\text { announcement } \\
\text { week }\end{array}$ & $\begin{array}{l}\text { (3) } \\
\text { Aggregate } \\
\text { Purchases (USD } \\
\text { Bil.) regressed on } \\
\text { each country's } \\
\text { yields }\end{array}$ & $\begin{array}{l}\text { (4) } \\
\text { (3) without the } \\
\text { annoncement } \\
\text { week }\end{array}$ \\
\hline \multicolumn{5}{|l|}{ 5-year sovereign yield } \\
\hline Const. & $\begin{array}{l}0.11^{4 * 4} \\
-0.02\end{array}$ & $\begin{array}{l}0.10^{4+4} \\
-0.02\end{array}$ & $\begin{array}{l}0.11^{4 * 4} \\
-0.02\end{array}$ & $\begin{array}{l}0.10^{4 * 4} \\
-0.02\end{array}$ \\
\hline Country panel & $\begin{array}{l}-0.27^{4 * 4} \\
-0.05\end{array}$ & $\begin{array}{l}-0.09 \\
-0.06\end{array}$ & & \\
\hline Reported weekly purchases & & & $\begin{array}{l}-0.03^{4+4} \\
-0.01\end{array}$ & $\begin{array}{l}0.00 \\
-0.01\end{array}$ \\
\hline R-Squared & $15.56 \%$ & $6.53 \%$ & $8.23 \%$ & $0.02 \%$ \\
\hline Regression standard error & 0.28 & 0.27 & 0.3 & 0.27 \\
\hline Observations & 240 & 236 & 240 & 236 \\
\hline
\end{tabular}

Note: Aggregated purchases are SMP purchases as reported by the ECB, in billions of euros, on the Tuesday following each purchase week. Country-level purchases are our estimates of the country breakdown of the ECB's SMP purchases based on market sources and news. *** indicates a p-value of 0.00 ; ** a p-value less than 0.05 ; and * a p-value between 0.05 and 0.1 .

We next examine the effects of SMP purchases in the second phase of the program, which we define as spanning the period from the announcement of the expansion of the program on August 8, 2011 to February 10, 2012, the Friday of the week of the last SMP purchase the ECB reported on its balance sheet. In this period, we believe the ECB switched to purchasing Italian, Spanish, and a small amount of Portuguese debt and so we focus our attention on those countries. Results are reported in Table 4. We find virtually no statistically significant effects of SMP purchases on change in 5-year yields in the second phase of the SMP, even when we include the announcement of the re-instatement of the program. We do find a weakly significant 
average fall in 5-year sovereign yields of 2 basis points per billion euros spent through the SMP. But even this flimsy significance vanishes once the data from the week of the announcement of the expansion of the SMP is removed (columns two and four of Table 4). Furthermore, in comparison to the results reported in Table 3, the regression standard errors are dramatically higher, and the explanatory power of the regression remains close to that of the full period panel regression in Table 2.

Table 4: Relationship between the ECB's purchases in the second phase of the SMP and changes in 5-year sovereign bond yields.

\begin{tabular}{|c|c|c|c|c|}
\hline \multirow[b]{2}{*}{ Weekly percentage point change } & (1) & (2) & (3) & (4) \\
\hline & $\begin{array}{l}\text { Country-breakdown } \\
\text { of purchases [\% } \\
\text { outstanding debt] } \\
\text { regressed on } \\
\text { country yields }\end{array}$ & $\begin{array}{l}\text { (1) without the } \\
\text { announcement } \\
\text { week }\end{array}$ & $\begin{array}{l}\text { Aggregate } \\
\text { Purchases (USD } \\
\text { Bil.) regressed on } \\
\text { each country's } \\
\text { yields }\end{array}$ & $\begin{array}{l}\text { (3) without the } \\
\text { announcement } \\
\text { week }\end{array}$ \\
\hline \multicolumn{5}{|l|}{ 5-year sovereign yield } \\
\hline \multirow[t]{2}{*}{ Constant } & 0.01 & -0.05 & 0.05 & -0.1 \\
\hline & -0.08 & -0.08 & -0.09 & -0.09 \\
\hline \multirow[t]{2}{*}{ Country panel } & -0.43 & 0.39 & & \\
\hline & -0.33 & -0.38 & & \\
\hline \multirow[t]{2}{*}{ Reported weekly purchases } & & & $-0.02^{*}$ & 0.02 \\
\hline & & & -0.01 & -0.01 \\
\hline R-Squared & $3.53 \%$ & $3.65 \%$ & $2.93 \%$ & $2.14 \%$ \\
\hline Regression standard error & 0.66 & 0.59 & 0.65 & 0.59 \\
\hline Observations & 108 & 104 & 108 & 108 \\
\hline
\end{tabular}

Note: The aggregated purchases are the SMP purchases as reported by the ECB, in billions of euros, on the Tuesday following each purchase week. Country-level purchases are our estimates of the country breakdown of the ECB's SMP purchases in billions of euros. Based on market sources and news. *** indicates a p-value of 0.00 ; ** a p-value less than 0.05 ; and * a p-value between 0.05 and 0.1 .

This disparity in effect between the two phases of the SMP makes intuitive sense. While the ECB purchased far more debt in the second phase of the SMP (the ECB reported 77.9 billion euros of purchases in the first phase and 145.3 billion euros in the second), we estimate that they purchased a far greater proportion of Irish, Portuguese, and Greek outstanding debt than Spanish or Italian debt. We estimate that the ECB bought 19 percent of all Irish outstanding debt (see Table 1), and 22.9 percent of all Portuguese debt. In contrast, the ECB holds only 7.5 and 5.2 percent of Spanish and Italian debt, respectively. Thus it is not surprising that we find a significant purchase effect in the first phase of the SMP, where we believe only Irish, 
Portuguese, and Greek debt was purchased, and no statistically significant effect at all for the second phase of the SMP when the ECB focused on Spanish and Italian debt.

\section{VIb. Regressions at the Country Level}

We utilize our country breakdown of the ECB's SMP purchases to check if the effect we observed in our panel regressions above were driven by a single outlier country or were generally consistent across countries. We run a simple OLS for each country, conditional on the ECB purchasing that country's debt. We also include Germany when we regress the aggregate SMP purchases on yield changes as a control. We regress the average weekly change in the country's 5-year sovereign yields on the weekly time series of our estimation of each country's SMP purchases and on the total amount of purchases for each week, as reported on the ECB's balance sheet on the Tuesday following each purchase. The results of the individual regressions for these countries over the period of the first phase of the SMP are reported in Table 5. As above, the odd-numbered columns are the results from running the regressions over the entire period and the even-numbered columns are from regressions that exclude the announcement week.

When we compare changes in 5-year yields with our estimates of the amount bought by the ECB from each country's outstanding debt (see column 1, Table 5), we see that the first phase of the SMP had a small but statistically significant negative effect on Irish, Portuguese, and Greek yields. For every percent of outstanding debt purchased by the ECB, we estimate that Irish yields fell by approximately 18 basis points, Portuguese yields by approximately 45 basis points, and Greek yields fell by approximately 30 basis points. At the aggregate, reported, level of purchases (see column 3, Table 5), we estimate that for every billion euros of peripheral debt purchased by the ECB, Irish yields decreased approximately 5 basis points and Portuguese and Greek yields decreased around 7 basis points. All the full period results are strongly or moderately significant and the Portuguese results, in particular, explain approximately a quarter of the variation in the data.

However, this strong estimated 'SMP treatment effect' again disappears once we remove the weeks of the announcement of the SMP in May 2010 and the program's revamp in August 2011. Though the effect is not significant, it is interesting that the direction of the effect 
Table 5: Relationship between each country's weekly change in average 5-year yields and the ECB's purchases in the first phase of the SMP

\begin{tabular}{|c|c|c|c|c|}
\hline Weekly percentage point change & $\begin{array}{l}\quad(1) \\
\text { Country-breakdown } \\
\text { of purchases [\% } \\
\text { outstanding debt] } \\
\text { regressed on } \\
\text { country yields } \\
\end{array}$ & $\begin{array}{l}\text { (2) } \\
\text { (1) without the } \\
\text { announcement } \\
\text { week }\end{array}$ & $\begin{array}{c}\text { (3) } \\
\text { A.ggregate } \\
\text { Purchases (USD } \\
\text { Bil.) regressed on } \\
\text { each country's } \\
\text { yields } \\
\end{array}$ & $\begin{array}{l}\text { (4) } \\
\text { (3) without the } \\
\text { announcement } \\
\text { week }\end{array}$ \\
\hline \multicolumn{5}{|l|}{ Irish 5-year sovereign yield } \\
\hline Constant & $\begin{array}{l}0.19^{4+4} \\
-0.06\end{array}$ & $\begin{array}{l}0.17^{4+4} \\
-0.06\end{array}$ & $\begin{array}{l}0.20^{4+4} \\
-0.06\end{array}$ & $\begin{array}{l}0.18^{4+4} \\
-0.06\end{array}$ \\
\hline Country panel & $\begin{array}{l}-0.18^{* *} \\
-0.08\end{array}$ & $\begin{array}{l}-0.04 \\
-0.11\end{array}$ & & \\
\hline Reported weekly purchases & & & $\begin{array}{l}-0.05^{* 4} \\
-0.02\end{array}$ & $\begin{array}{l}-0.02 \\
-0.02\end{array}$ \\
\hline R-Squared & $9.22 \%$ & $0.21 \%$ & $10.56 \%$ & $0.88 \%$ \\
\hline $\begin{array}{l}\text { Regression standard error } \\
\text { Observations }\end{array}$ & $\begin{array}{l}0.4 \\
60\end{array}$ & $\begin{array}{c}0.39 \\
59\end{array}$ & $\begin{array}{l}0.4 \\
60\end{array}$ & $\begin{array}{c}0.39 \\
59\end{array}$ \\
\hline \multicolumn{5}{|l|}{ Portuguese 5-year sovereign yield } \\
\hline Constant & $\begin{array}{l}0.22^{4 * *} \\
-0.05\end{array}$ & $\begin{array}{l}0.18^{4 * 4} \\
-0.05\end{array}$ & $\begin{array}{l}0.20^{* 4 *} \\
-0.05\end{array}$ & $\begin{array}{l}0.17^{444} \\
-0.05\end{array}$ \\
\hline Country panel & $\begin{array}{l}-0.45^{* * * *} \\
-0.1\end{array}$ & $\begin{array}{l}-0.18 \\
-0.12\end{array}$ & & \\
\hline Reported weekly purchases & & & $\begin{array}{l}-0.07^{+4 *} \\
-0.02\end{array}$ & $\begin{array}{l}-0.02 \\
-0.02\end{array}$ \\
\hline R-Squared & $24.97 \%$ & $3.52 \%$ & $21.95 \%$ & $0.99 \%$ \\
\hline Regression standard error & 0.35 & 0.32 & 0.36 & 0.33 \\
\hline Observations & 60 & 59 & 60 & 59 \\
\hline \multicolumn{5}{|l|}{ Greek 5-year sovereign yield } \\
\hline Constant & $\begin{array}{l}0.19^{4 *} \\
-0.08\end{array}$ & $\begin{array}{l}0.15^{*} \\
-0.08\end{array}$ & $\begin{array}{l}0.21^{4 *} \\
-0.08\end{array}$ & $\begin{array}{l}0.16^{*} \\
-0.08\end{array}$ \\
\hline Country panel & $\begin{array}{l}-0.30^{* 4} \\
-0.14\end{array}$ & $\begin{array}{l}0.11 \\
-0.17\end{array}$ & & \\
\hline Reported weekly purchases & & & $\begin{array}{l}-0.07^{* 4} \\
-0.03\end{array}$ & $\begin{array}{r}0.00 \\
-0.03\end{array}$ \\
\hline R-Squared & $7.12 \%$ & $0.75 \%$ & $11.58 \%$ & $0.03 \%$ \\
\hline Regression standard error & 0.6 & 0.54 & 0.59 & 0.54 \\
\hline Observations & 60 & 59 & 60 & 59 \\
\hline \multicolumn{5}{|l|}{ German 5-year sovereign yield } \\
\hline Constant & & & $\begin{array}{l}0.01 \\
-0.01\end{array}$ & $\begin{array}{l}0.02 \\
-0.01\end{array}$ \\
\hline \multicolumn{5}{|l|}{ Country panel } \\
\hline Reported weekly purchases & & & $\begin{array}{c}-0.01 \\
0.00\end{array}$ & $\begin{array}{c}-0.01 \\
0.01\end{array}$ \\
\hline R-Squared & & & $5.44 \%$ & $4.79 \%$ \\
\hline Regression standard error & & & 0.09 & 0.09 \\
\hline Observations & & & 60 & 59 \\
\hline
\end{tabular}

Note: Aggregated purchases are the SMP purchases as reported by the ECB, in billions of euros, on the Tuesday following each purchase week. Country-level purchases are our estimates of the country breakdown of the ECB's SMP purchases in billions of euros. Based on market sources and news. *** indicates a p-value of 0.00 ; ** a p-value less than 0.05 ; and * a p-value between 0.05 and 0.1 . 
Table 6: Relationship between each country's weekly change in average 5-year yields and the ECB's purchases in the second phase of the SMP

\begin{tabular}{|c|c|c|c|c|}
\hline Weekly percentage point change & $\begin{array}{c}\text { (1) } \\
\text { Country-breakdown } \\
\text { of purchases [\% } \\
\text { outstanding debt) } \\
\text { regressed on } \\
\text { country yields }\end{array}$ & $\begin{array}{l}\text { (2) } \\
\text { (1) without the } \\
\text { announcement } \\
\text { week }\end{array}$ & $\begin{array}{c}\text { (3) } \\
\text { Aggregate } \\
\text { Purchases (USD } \\
\text { Bil.) regressed on } \\
\text { each country's } \\
\text { yields }\end{array}$ & $\begin{array}{l}\text { (4) } \\
\text { (3) without the } \\
\text { announcement } \\
\text { week }\end{array}$ \\
\hline \multicolumn{5}{|l|}{ Italian 5-year sovereign yield } \\
\hline \multirow[t]{2}{*}{ Constant } & -0.07 & $-0.19^{*}$ & -0.04 & $-0.18^{*}$ \\
\hline & -0.12 & -0.1 & -0.12 & -0.1 \\
\hline \multirow[t]{2}{*}{ Country panel } & 0.12 & $1.09^{* *}$ & & \\
\hline & -0.43 & -0.41 & & \\
\hline \multirow[t]{2}{*}{ Reported weekly purchases } & & & 0.00 & $0.04^{* *}$ \\
\hline & & & -0.02 & -0.02 \\
\hline R-Squared & $0.32 \%$ & $22.95 \%$ & $0.00 \%$ & $20.35 \%$ \\
\hline Regression standard error & 0.43 & 0.33 & 0.43 & 0.34 \\
\hline Observations & 27 & 26 & 27 & 26 \\
\hline \multicolumn{5}{|c|}{ Portuguese 5-year sovereign yield } \\
\hline \multirow[t]{2}{*}{ Constant } & 0.44 & 0.33 & 0.31 & 0.16 \\
\hline & -0.29 & -0.3 & -0.28 & -0.31 \\
\hline \multirow[t]{2}{*}{ Country panel } & $-4.51^{*}$ & -2.45 & & \\
\hline & -2.43 & -2.97 & & \\
\hline \multirow[t]{2}{*}{ Reported weekly purchases } & & & -0.04 & 0.00 \\
\hline & & & -0.04 & -0.05 \\
\hline R-Squared & $12.08 \%$ & $2.78 \%$ & $5.67 \%$ & $0.02 \%$ \\
\hline Regression standard error & 1.04 & 1.04 & 1.06 & 1.05 \\
\hline Observations & 27 & 26 & 27 & 26 \\
\hline \multicolumn{5}{|l|}{ Spanish 5-year sovereign yield } \\
\hline \multirow[t]{2}{*}{ Constant } & 0.01 & -0.11 & -0.01 & -0.13 \\
\hline & -0.09 & -0.08 & -0.1 & -0.08 \\
\hline \multirow[t]{2}{*}{ Country panel } & -0.24 & 0.36 & & \\
\hline & -0.21 & -0.21 & & \\
\hline \multirow[t]{2}{*}{ Reported weekly purchases } & & & -0.01 & $0.02^{*}$ \\
\hline & & & -0.01 & -0.01 \\
\hline R-Squared & $5.10 \%$ & $10.77 \%$ & $2.38 \%$ & $13.62 \%$ \\
\hline Regression standard error & 0.35 & 0.27 & 0.35 & 0.26 \\
\hline Observations & 27 & 26 & 27 & 26 \\
\hline \multicolumn{5}{|l|}{ German 5-year sovereign yield } \\
\hline \multirow[t]{2}{*}{ Constant } & & & 0.01 & 0.01 \\
\hline & & & -0.03 & -0.03 \\
\hline \multicolumn{5}{|l|}{ Country panel } \\
\hline \multirow[t]{2}{*}{ Reported weekly purchases } & & & -0.01 & -0.01 \\
\hline & & & 0.00 & -0.01 \\
\hline R-Squared & & & $14.02 \%$ & $7.86 \%$ \\
\hline Regression standard error & & & 0.11 & 0.11 \\
\hline Observations & & & 27 & 26 \\
\hline
\end{tabular}

Note: Aggregated purchases are the SMP purchases as reported by the ECB, in billions of euros, on the Tuesday following each purchase week. Country-level purchases are our estimates of the country breakdown of the ECB's SMP purchases in billions of euros. Based on market sources and news. *** indicates a p-value of 0.00 ; ** a p-value less than 0.05 ; and * a p-value between 0.05 and 0.1 . 
of the SMP purchases on German 5-year sovereign yield changes is negative. As the risk-free asset in the Euro zone, we would expect that if SMP purchases had resulted in lower peripheral yields, on average, that they would conversely result in higher German yields.

The individual country regressions run from the announcement of the expansion of the SMP on August 8, 2011, show little of significance amid high standard errors (see columns one and three of Table 6). For Portugal, we have a weakly significant result that for every percent of Portuguese debt bought by the ECB, Portuguese 5-year sovereign yields declined approximately 5 percentage points, yet the standard error on the coefficient is also very high as well as the standard error of the regression.

When we exclude announcement effects (columns two and four of Table 6), even that small effect on Portuguese yields disappears while the standard errors remain high. For Italy, the effect of the SMP becomes moderately significant. However, contrary to our hypothesis that SMP purchases would lower yields, the estimated effect of the ECB's purchases on yields is positive, suggesting that for every billion euros of Italian debt purchased by the ECB, Italian yields rose 4 basis points. Similarly, for every percent of Italian outstanding debt the ECB bought, Italian yields rose 1.09 percentage points. We do not attribute these findings to the ECB's purchases. Rather, any effect the ECB's purchases may have had to lower Italian yields over the period appear to have been more than counteracted by the strong upward trend in Italian yields from other factors.

\section{VIc. Robustness: Checking for Sensitivity to Data Availability}

Our regression analysis found no significant effect of the SMP purchases beyond announcement effects at the beginning of the program and at its expansion a year later. However, all of the above is predicated on the assumption that weekly data is an appropriate frequency for testing such a response - recall that the official ECB data is only available at a weekly frequency and only at a program-aggregated level. Although all peripheral bond yields dropped sharply in response to the initiation of each of the SMP's two phases, yields rose over the sample period as a whole. Thus, at a weekly frequency, the effects of the ECB's purchases may not be apparent. Simply regressing the weekly change in yields on the country-specific SMP purchase discounts the intraweek effects of the intervention by the overall upward trend in

yields (for example, see Figure 13). Thus any effect of the SMP on peripheral sovereign yields is likely in lowering the trajectory of the increase in peripheral yields over the period, instead of 
resulting in an absolute decrease in yields. If true, this effect is hard to quantify econometrically with the data that is publically available.

In lieu of access to the ECB's detailed, intraweek SMP purchase data, we turned to financial media coverage of the European Debt Crisis and the ECB's actions during the period the SMP was extant. We used these reports and commentary as a window into what the market knew or suspected about purchases at the time and thus what influenced resulting yield movements. We combed through the Dow Jones' Factiva news archive over the more than two years from the beginning of the European Debt Crisis in October 2009 to the official termination of the SMP in August 2012. Our selection was more detailed during the period of active SMP purchases from May 10, 2010 to February 10, 2012. We selected events the market identified as having an effect on yields (whether or not that effect was attributed to the ECB) and constructed a timeline which we lined up with the time series of changes in 5-year peripheral Europe sovereign bond yields (see Appendix).

We can use this knowledge to test if our lack of results beyond announcement effects is completely due to the nature of the data the ECB released. We regress the daily change in 5-year rates on a dummy that is one if there is a report that day that the ECB exercised the SMP to buy peripheral debt (column one of Table 6). We found no significant change in 5-year sovereign yields on purchase days when we excluded for announcement effects. But this method weights every intervention as equally important, whereas we can clearly see from Figure 4 that the ECB varied the size of its purchases considerably throughout the program. So we further regress yield changes on the market sighting dummy interacted with the SMP purchases reported that week divided evenly across every day identified in a given week (column two of Tables 7 and 8). We divide the week's reported purchases evenly across all identified days that week as we have no indication of how much was spent any given day. We do not break down purchases by country because the reports do not always identify which countries' debt traders believed the ECB purchased. The test, therefore, does not serve as a more refined version of our base regressions, but rather a check that those results are not driven by mistiming. Results confirm our findings above - we find no significant effects when announcement days are excluded. 
Table 7: Relationship between daily changes in country 5-year yields on days the market believed the ECB use the SMP to make purchases over the first phase of the SMP

(1)

$\begin{array}{lc}\text { Identified purchase dummy } & \begin{array}{c}\text { Identified purchase dummy } \\ \text { interacted with aggregate }\end{array} \\ \text { regressed on country yields } & \text { SMP purchases regressed on } \\ \text { country yields }\end{array}$

\begin{tabular}{|c|c|c|}
\hline \multicolumn{3}{|l|}{ Irish 5-year sovereign yield } \\
\hline \multirow[t]{2}{*}{ Constant } & $0.027^{* 4 *}$ & $0.029^{* 4 *}$ \\
\hline & -0.01 & -0.01 \\
\hline \multirow[t]{2}{*}{ Market sighting dummy } & 0.025 & \\
\hline & -0.03 & \\
\hline \multirow[t]{2}{*}{ Market sighting dummy x SMP purchases } & & 0.004 \\
\hline & & -0.01 \\
\hline R-Squared & $0.22 \%$ & $0.05 \%$ \\
\hline Regression standard error & 0.16 & 0.16 \\
\hline Observations & 299 & 299 \\
\hline \multicolumn{3}{|l|}{ Portuguese 5-year sovereign yield } \\
\hline \multirow[t]{2}{*}{ Constant } & $0.030^{* 4 *}$ & $0.026^{* * *}$ \\
\hline & -0.01 & -0.01 \\
\hline \multirow[t]{2}{*}{ Market sighting dummy } & -0.019 & \\
\hline & -0.02 & \\
\hline \multirow[t]{2}{*}{ Market sighting dummy x SMP purchases } & & 0.002 \\
\hline & & -0.01 \\
\hline R-Squared & $0.23 \%$ & $0.03 \%$ \\
\hline Regression standard error & 0.14 & 0.14 \\
\hline Observations & 299 & 299 \\
\hline \multicolumn{3}{|l|}{ Greek 5-year sovereign yield } \\
\hline \multirow[t]{2}{*}{ Constant } & $0.038^{* 4 *}$ & $0.041^{* * *}$ \\
\hline & -0.01 & -0.01 \\
\hline \multirow[t]{2}{*}{ Market sighting dummy } & -0.061 & \\
\hline & -0.04 & \\
\hline \multirow[t]{2}{*}{ Market sighting dummy x SMP purchases } & & $-0.055^{* * *}$ \\
\hline & & -0.01 \\
\hline R-Squared & $0.74 \%$ & $4.88 \%$ \\
\hline Regression standard error & 0.22 & 0.21 \\
\hline Observations & 299 & 299 \\
\hline \multicolumn{3}{|l|}{ German 5-year sovereign yield } \\
\hline \multirow[t]{2}{*}{ Constant } & 0.002 & 0.002 \\
\hline & 0.00 & 0.00 \\
\hline \multirow[t]{2}{*}{ Market sighting dummy } & -0.011 & \\
\hline & -0.01 & \\
\hline \multirow[t]{2}{*}{ Market sighting dummy x SMP purchases } & & -0.005 \\
\hline & & 0.00 \\
\hline R-Squared & $0.42 \%$ & $0.62 \%$ \\
\hline Regression standard error & 0.05 & 0.05 \\
\hline Observations & 299 & 299 \\
\hline
\end{tabular}

Note: $* * *$ indicates a p-value of $0.00 ; * *$ a p-value less than 0.05 ; and * a p-value between 0.05 and 0.1 . 
Table 8: Relationship between daily changes in country 5-year yields on days the market believed the ECB use the SMP to make purchases over the second phase of the SMP

(1)

Identified purchase dummy Identified purchase dummy
regressed on country yields Daily percentage point change regressed on country yields SMP purchases regressed on
country yields

Italian 5-year sovereign yield

Constant

$-0.002$

$-0.006$

$-0.02$

$-0.02$

Market sighting dummy

$-0.017$

$-0.03$

Market sighting dummy x SMP purchases

$-0.003$

$-0.01$

R-Squared

Regression standard error

$0.18 \%$

0.2

135

$0.07 \%$

Observations

$-0.018$

0.2

Portuguese 5-year sovereign yield

Constant

$-0.04$

0.073

$-0.07$

Market sighting dummy $x$ SMP purchases

R-Squared

Regression standard error

Observations

Spanish 5-year sovereign yield

Constant

Market sighting dummy

Market sighting dummy x SMP purchases

R-Squared

Regression standard error

Observations

German 5-year sovereign yield

Constant

Market sighting dummy

Market sighting dummy x SMP purchases

R-Squared

Regression standard error

Observations

\begin{tabular}{|c|c|}
\hline & $\begin{array}{c}-0.011 \\
-0.02\end{array}$ \\
\hline $0.86 \%$ & $0.31 \%$ \\
\hline 0.38 & 0.38 \\
\hline 135 & 135 \\
\hline-0.014 & -0.006 \\
\hline-0.02 & -0.01 \\
\hline \multicolumn{2}{|l|}{0.005} \\
\hline \multicolumn{2}{|l|}{-0.03} \\
\hline & -0.005 \\
\hline & -0.01 \\
\hline $0.03 \%$ & $0.47 \%$ \\
\hline 0.15 & 0.15 \\
\hline 135 & 135 \\
\hline-0.001 & -0.003 \\
\hline-0.01 & -0.01 \\
\hline \multicolumn{2}{|l|}{-0.007} \\
\hline \multicolumn{2}{|l|}{-0.01} \\
\hline & -0.001 \\
\hline & 0.00 \\
\hline $0.32 \%$ & $0.17 \%$ \\
\hline 0.06 & 0.06 \\
\hline 135 & 135 \\
\hline
\end{tabular}

Note: $* * *$ indicates a p-value of $0.00 ; * *$ a p-value less than 0.05 ; and * a p-value between 0.05 and 0.1 . 


\section{Conclusion}

In the low-interest rate environment prevalent in most advanced economies, asset purchase programs are a key option in the central banker's toolbox, potentially achieving many of the objectives of traditional monetary policy. However, from both the recent literature and our own findings, it is clear that the efficacy of such programs is dependent on the way they are structured. In this paper, we draw lessons from the ECB's SMP program, by testing the systematic success of SMP purchases in lowering peripheral yields and spreads. Although the ECB did not claim this as a goal of the SMP, it was the metric by which contemporary market commentary examined the program and the focus of empirical examination of comparable asset purchase programs such as those of the Federal Reserve (e.g., Gagnon et al. 2011 and D’Amico et al. 2012, 2013) and of the Bank of England (e.g. Joyce et al. 2011).

We were unable to empirically find a significant effect of SMP bond purchases on bond yields absent announcement effects, though there may have been a downward shift in the upward yield trend instead of an absolute decline. This finding is consistent with the results of De Pooter et al. (2014) who find that the ECB did achieve its goal of improving market functioning and restoring the monetary transmission mechanism within the euro area by improving liquidity conditions in European sovereign bond markets.

Because we do find a substantial announcement effect, we conclude that any efficacy of the SMP arose not from the size or timing of the purchases themselves but rather via a communications or, perhaps, a confidence channel. More work needs to be done to understand how such channels work. In this particular euro-area context, market participants may have genuinely believed that there was a substantial risk of euro-area dissolution, and that activist monetary policy of any sort reduced that risk. Alternatively, they may have interpreted the ECB's announcements as a willingness of central European authorities to absorb the credit risk

of the smaller countries. Understanding these alternative channels rather than trying to quantify the elasticity of the purchase effect may be a fruitful avenue of future research. 


\section{Bibliography}

Andrés, Javier, J. David López-Salido, and Edward Nelson. "Tobin's imperfect asset substitution in optimizing general equilibrium." Journal of Money, Credit and Banking (2004): 665-690.

Brunner, Karl, and Allan H. Meltzer. "Mr. Hicks and the" Monetarists"." Economica (1973): 44-59.

Christensen, Jens HE, and Glenn D. Rudebusch. "The Response of Interest Rates to US and UK Quantitative Easing*." The Economic Journal 122, no. 564 (2012): F385-F414.

Curdia, Vasco, and Michael Woodford. "The central-bank balance sheet as an instrument of monetary policy." Journal of Monetary Economics 58, no. 1 (2011): 54-79.

D’Amico, Stefania, William English, David López-Salido, and Edward Nelson. "The Federal Reserve's Large-scale Asset Purchase Programmes: Rationale and Effects*." The Economic Journal 122, no. 564 (2012): F415-F446.

D’Amico, Stefania, and Thomas B. King. "Flow and stock effects of large-scale treasury purchases: Evidence on the importance of local supply." Journal of Financial Economics 108, no. 2 (2013): 425-448.

De Pooter, Michiel, R. Martin, and Seth Pruitt. "The Liquidity Effects of Official Bond Market Intervention." Available at SSRN 2143326 (2014).

Eggertsson, Gauti, and Michael Woodford. "Optimal Monetary and Fiscal Policy in a Liquidity Trap." NBER Working Paper w10840 (2004).

Fawley, Brett W., and Christopher J. Neely. "Four stories of quantitative easing." Federal Reserve Bank of St. Louis Review 95, no. January/February 2013 (2013).

Gagnon, Joseph, Matthew Raskin, Julie Remache, and Brian Sack. "The financial market effects of the Federal Reserve’s large-scale asset purchases." International Journal of Central Banking 7, no. 1 (2011): 3-43.

Gambacorta, Leonardo, Boris Hofmann, and Gert Peersman. “The Effectiveness of Unconventional Monetary Policy at the Zero Lower Bound: A Cross-Country Analysis.” No. 384. Bank for International Settlements, 2012.

Greenwood, Robin, and Dimitri Vayanos. "Bond Supply and Excess Bond Returns." Review of Financial Studies (2014): hht133.

Gürkaynak, Refet S., Brian Sack, and Jonathan H. Wright. "The US Treasury yield curve: 1961 to the present." Journal of Monetary Economics 54, no. 8 (2007): 2291-2304.

Hamilton, James D., and Jing Cynthia Wu. "The effectiveness of alternative monetary policy tools in a zero lower bound environment." Journal of Money, Credit and Banking 44, no. s1 (2012): 3-46. 
Joyce, Michael, Ana Lasaosa, Ibrahim Stevens, and Matthew Tong. "The financial market impact of quantitative easing in the United Kingdom." International Journal of Central Banking 7, no. 3 (2011): 113-161.

Joyce, Michael, David Miles, Andrew Scott, and Dimitri Vayanos. "Quantitative Easing and Unconventional Monetary Policy-an Introduction*." The Economic Journal 122, no. 564 (2012): F271-F288.

Kim, Don H., and Jonathan H. Wright. "An Arbitrage-Free Three-Factor Term Structure Model and the Recent Behavior of Long-Term Yields and Distant-Horizon Forward Rates." No. 2005-33. Board of Governors of the Federal Reserve System (US), 2005.

Kiyotaki, Nobuhiro, and John Moore. Liquidity, business cycles, and monetary policy. No. w17934. National Bureau of Economic Research, 2012.

Kozicki, Sharon, Eric Santor, and Lena Suchanek. "Central bank balance sheets and long-term forward rates." Interest Rates, Prices and Liquidity: Lessons from the Financial Crisis (2011): 172.

Krishnamurthy, Arvind, and Annette Vissing-Jorgensen. The effects of quantitative easing on interest rates: channels and implications for policy. No. w17555. National Bureau of Economic Research, 2011.

Martin, Christopher. "Foreign Treasury Purchases and the Yield Curve: Evidence from a SignIdentified Vector Autoregression.” Working Paper (2013). http://www.econ2.jhu.edu/jobmarket/2013/MartinCA/JobPaper/JobMarketPaperMartinCA.pdf

Martin, Robert F. The baby boom: predictability in house prices and interest rates. Board of Governors of the Federal Reserve System, 2005.

Meaning, Jack, and Feng Zhu. "The impact of recent central bank asset purchase programmes." Bank of International Settlements Quarterly Review 4 (2011): 73-83.

Modigliani, Franco, and Richard Sutch. "Innovations in interest rate policy." The American Economic Review (1966): 178-197.

Neely, Christopher J. “The large scale asset purchases had large international effects”. Federal Reserve Bank of St. Louis Working Paper No. 2010-018A.

Nelson, Charles R., and Andrew F. Siegel. "Parsimonious modeling of yield curves." Journal of business 60, no. 4 (1987): 473.

Stroebel, Johannes, and John B. Taylor. "Estimated Impact of the Federal Reserve's MortgageBacked Securities Purchase Program." International Journal of Central Banking 8, no. 2 (2012): 1-42.

Tobin, James. "Money, capital, and other stores of value." The American Economic Review (1961): 26-37. 
Tobin, James. "An essay on the principles of debt management”, in Commission on Money and Credit, Fiscal and Debt Management Policies (1963), pp. 143-218, Englewood Cliffs, NJ: Prentice Hall.

Tobin, James. "A general equilibrium approach to monetary theory." Journal of money, credit and banking 1, no. 1 (1969): 15-29.

Vayanos, Dimitri, and Jean-Luc Vila. A preferred-habitat model of the term structure of interest rates. No. w15487. National Bureau of Economic Research, 2009. 


\section{Appendix to De Pooter, DeSimone, Martin, and Pruitt (2015): Cheap Talk and the Efficacy}

of the ECB's SMP: Did bond purchases matter?

In this appendix we provide a detailed timeline of the ECB's SMP program and daily estimates of SMP purchases of Portuguese, Irish, Greek, Spanish, and Italian government debt. Our sources were primarily the Wall Street Journal, the Financial Times, the Dow Jones Newswire, Reuters Newswire, and the Associated Press. We only included English-language articles. While we cannot help but select what is important through the eyes of hindsight, we began construction off a pre-existing internal database, maintained daily by Federal Reserve economists in the International Finance Division, of news that they identified as important on the day of the event. So, for example, on January 18, 2012 when Portugal had a strong auction and reassured markets, there were several articles and commentaries on the sale included in that database throughout the day. While we augmented this pre-existing database, this source also provided a unique view of what topics international economists at the Fed thought were important at the time.

Referencing Table A, the first column provides the date of the news event. For the sake of conciseness, we only include days on which identified news takes place in the table. But the next two columns identify the week so that the impact of news on a particular day can be easily viewed in the context of other news that week, at the frequency of the SMP purchase data we use in our regressions above. The following column contains a short description of the eventusually the byline of the article itself. The next columns contain the entity with which the news is associated. If the news concerns more than one entity, each gets its own row. The total amount of purchases, if any, the ECB reported for that week in billions of euros is recorded in the next column, and then the quantity of those purchases we estimate were used to purchase the newsentity's bonds. We then match the dates with the change in the news-entity's corresponding 5year sovereign bond yield as well as the change in the 5-year German yield (the euro-area proxy for the risk free rate) and the weekly average of the news-entity's yield. Next we provide a short week summary of the major events and investor sentiment. If it is a purchase week, we identify the country whose bonds we believe the ECB concentrated its purchases on and the country or countries whose borrowing costs the media was focused on that week.

In our example of the Portuguese auction on January 18, 2012, the SMP purchase week was the week of January 16, to January 20, 2012 during which the ECB reported it purchased 
approximately 2.2 billion euros of peripheral sovereign debt. We estimate from counterparty reports that 44 million euros of that was used to buy Portuguese debt. Portuguese yields actually rose 30 basis points that day, despite the strong auction. A glance at the weekly summary suggests that this was in the context of a general and persistent rise in Portugal's borrowing cost from the time it was downgraded by Standard \& Poor's to junk status on the preceding Monday, January 13. The market had started to focus on Portugal that week, but we believe the ECB was still focusing its buying in the Italian secondary market.

From this thorough look at the events of the European debt crisis as chronicled in the world's English-language financial media, we can present a more detailed view of the evolution of the crisis for each of the peripheral countries that the ECB included in its SMP program. For example, from the announcement of the SMP on May 10, 2010 to late August 2010, the financial media and the ECB were broadly in agreement that Greece and its first bailout were the nexus of the European Debt Crisis and that, once this one outlier country got its fiscal affairs in order, market turmoil would disappear. This viewpoint informed the way the ECB designed the SMP with the idea of ensuring 'effective monetary policy transmission' in the interim. By mid-August investors began to fear that Ireland would also require a bailout when its rescue of large national bank Anglo Irish turned out to be more expensive than anyone had projected. The ECB had already shifted focus to Portugal by the time Ireland accepted an EU bailout on November 21, 2010. Portugal's banks were virtually cut off from capital markets because of Portugal's rising yields - attributed in the media to contagion from Ireland. After the country missed several deficit-reduction deadlines, Portuguese 10-year yields pushed above $8 \%$ to a euro-era high in March 2011. Turmoil subsided after Portuguese Prime Minister Jose Socrates requested a bailout April 6, 2011.

By the summer of 2011 yields began risking in Italy and Spain as well and a sovereign debt crisis morphed into a potential banking crisis after large banks in peripheral countries including Spain, Italy, and Ireland failed or barely passed European Banking Authority bank stress tests. In one instance, on July 16, 2011, it was announced that five Spanish banks failed EBA tests and seven more barely passed. At the same time the credit worthiness of intra-country regions, particularly in Spain, were brought to the forefront by a serious of downgrades.

Meanwhile, Italian political events made investors nervous about its government's ability to unite behind austerity as scandal dogged Economy Minister Guilio Tremonti and Prime 
Minister Silvio Berlusconi. S\&P cut Italy’s credit rating for the first time in almost five years on September 20, 2011 and the rating of seven Italian banks the next day. In addition to internal problems meeting deficits and shoring up banks and regions, Italy and Spain suffered further from Greek contagion after, on October 31, 2011, Greek Prime Minister Papandreaou called a surprise referendum on a proposed second Greek bailout. The next day, November 1, the Milan Stock Exchange plunged 6.8\% in its worst session since the start of the crisis and on November 4, Italy was forced to agree to 'special surveillance' from the IMF and EU of its austerity agenda. Berlusconi announced his resignation on November 10. By the beginning of 2012 both Italy and Spain had new governments under Mario Monti and Mariano Rajoy, respectively.

Though the ECB began large purchases again on August 12, 2011 after a four-month break (beginning a second, distinct phase of the SMP), markets remained jittery as European leaders prolonged discussions of if and how they would strengthen Europe's temporary bailout fund, the EFSF. New ECB president Mario Draghi, with the support of Germany, resisted their calls for the ECB to expand its SMP program, make massive sovereign debt purchases, and openly target yields. Calls for this type of program and criticism of the small size of purchases compared to the size of peripheral sovereign debt would never subside, particularly from peripheral governments, up to and even beyond the ECB's termination of the SMP and announcement of the Outright Monetary Transactions program on August 2, 2012. However, 2011 ended with brief market optimism after the ECB started a program to provide large amounts of long-term credit to European banks through 3-year Long Term Refinancing Operations. Governments encourage banks to use the ECB's money to buy their own country's sovereign debt. Strong debt auctions in Italy and Spain in January 2012 were attributed to domestic banks’ purchases with this money. The ECB conducted two more large bank liquidityproviding operations in 2012.

Portugal regained the euro-crisis spotlight after S\&P downgraded the country to junk status on January 13, 2012 (along with the rating on the EFSF and that of France, Austria, Spain, Italy and four other euro members) which led to a persistent increase in Portuguese borrowing costs - well beyond what was justified by the country’s fundamentals, according to Mario Draghi. The higher yield demanded to hold Portuguese debt was attributed to contagion from renewed turmoil in Greece as it continually delayed striking a deal with both its private and public creditors - the so called 'troika' of the EU, IMF and ECB — on the terms of a debt write 
down and a second bailout. As yields increased and Greek negotiations dragged on over several weeks, news reports expressed concern that Portugal would not be able to return to markets for funding in 2013, which would force the country to request a second bailout. Market pressure only subsided when a second Greek rescue package was approved by the EU member states on February 21, 2012 - two weeks after the last SMP purchase the ECB reports.

Even though the SMP purchases had ceased, market worries persisted about Spanish and Italian banks and the impact of their failure on the solvency of their countries. Spain effectively nationalized it largest bank, Bankia, on May 10, 2012. Spain accepted a 100 billion euro bank rescue package on June 9, 2012. The ECB officially ended the SMP and announced the OMT on August 2, 2012. Though growth and debt concerns persisted, at this point all the immediate euroarea fires appear to be addressed and markets calm considerably. As of the writing of this paper, the ECB has never initiated any purchases under its OMT program.

For $82 \%$ of the 69 weeks of purchase data reported on the ECB balance sheet, we found articles claiming the ECB entered a specific country's market and often what maturities they were believed to be buying. This public information from the time gives us insight into the information that markets were responding to. Keep in mind that we are not claiming that these reports represent the truth of when and what the ECB actually bought, but only what markets thought they bought, and therefore what traders were responding to. In fact, on two occasions, on February 9, 2011 and once August 4, 2011, there were reports that the ECB had entered the Irish and Portuguese markets. However, no purchases for those weeks were ever reported by the ECB. But given that the ECB was purchasing not to bring down yields themselves but to facilitate the market functioning in such a way as to lower yields, these market report days are a reasonable proxy for actual purchase day effectiveness of the SMP purchases. 


\section{Table A: Securities Market Programme timeline and market beliefs about purchase timing}

\begin{tabular}{|c|c|c|c|c|c|c|}
\hline \multirow[b]{2}{*}{ date } & \multirow[b]{2}{*}{ Description } & \multirow[b]{2}{*}{ News Entity } & \multicolumn{2}{|c|}{$\begin{array}{l}\text { ECB week purchase } \\
\text { amount (billions of euro) }\end{array}$} & \multirow[b]{2}{*}{$\begin{array}{l}\text { SMP } \\
\text { Focus } \\
\text { Country }\end{array}$} & \multirow[b]{2}{*}{$\begin{array}{l}\text { Media } \\
\text { Focus } \\
\text { Country }\end{array}$} \\
\hline & & & $\begin{array}{c}\text { Total } \\
\text { Reported } \\
\text { Purchases }\end{array}$ & $\begin{array}{l}\text { News Entity } \\
\text { Estimated } \\
\text { Purchases }\end{array}$ & & \\
\hline 11/5/09 & $\begin{array}{l}\text { Greece says } 2009 \text { budget deficit will be } \\
12.7 \text { percent of GDP; more than twice } \\
\text { the previously published figure. }\end{array}$ & Greece & N/A & N/A & Greece & Greece \\
\hline 12/8/09 & Fitch Ratings cuts Greek debt to BBB+. & Greece & N/A & N/A & Greece & Greece \\
\hline $12 / 16 / 09$ & $\begin{array}{l}\text { Standard \& Poor's cuts Greece's rating } \\
\text { by one notch to BBB+, citing lack of } \\
\text { efficacy in the austerity program. }\end{array}$ & Greece & N/A & N/A & Greece & Greece \\
\hline $12 / 22 / 09$ & $\begin{array}{l}\text { Moody's cuts Greek debt to A2 from A1 } \\
\text { over soaring deficits. }\end{array}$ & Greece & N/A & N/A & Greece & Greece \\
\hline $12 / 24 / 09$ & $\begin{array}{l}\text { Greece passes a } 2010 \text { budget reducing } \\
\text { the public deficit to } 9.1 \text { percent of GDP } \\
\text { in } 2010 \text {. The budget foresees debt } \\
\text { swelling to } € 295 \text { billion ( } \$ 373 \text { billion). }\end{array}$ & Greece & N/A & N/A & Greece & Greece \\
\hline $1 / 14 / 10$ & $\begin{array}{l}\text { Greece unveils Stability and Growth } \\
\text { program, pledging to cut its budget gap } \\
\text { to } 2.8 \text { percent of GDP in } 2012 \text {. }\end{array}$ & Greece & N/A & N/A & Greece & Greece \\
\hline $1 / 26 / 10$ & $\begin{array}{l}\text { Portugal confirms a record deficit of } 9.3 \\
\text { percent of GDP. }\end{array}$ & Portugal & N/A & N/A & Greece & Greece \\
\hline $1 / 29 / 10$ & $\begin{array}{c}\text { Spain adopts a three-year, } € 50 \text { billion } \\
\text { austerity plan. }\end{array}$ & Spain & N/A & N/A & Greece & Greece \\
\hline $2 / 2 / 10$ & $\begin{array}{l}\text { Greece announces a public sector wage } \\
\text { freeze will extend to those making } \\
\text { below } € 2,000 \text { a month. }\end{array}$ & Greece & N/A & N/A & Greece & Greece \\
\hline $2 / 3 / 10$ & $\begin{array}{l}\text { The European Union's executive } \\
\text { Commission approves Greece's austerity } \\
\text { plan, placing the country under } \\
\text { surveillance. }\end{array}$ & Greece & N/A & N/A & Greece & Greece \\
\hline 2/10/10 & $\begin{array}{l}\text { Thousands of Greek civil servants stage } \\
\text { a one-day strike against pay and pension } \\
\text { freezes. }\end{array}$ & Greece & N/A & N/A & Greece & Greece \\
\hline $2 / 11 / 10$ & $\begin{array}{l}\text { EU leaders hold first emergency summit } \\
\text { on Greece; agree to take coordinated } \\
\text { action to protect financial stability. }\end{array}$ & Greece & N/A & N/A & Greece & Greece \\
\hline $2 / 24 / 10$ & $\begin{array}{l}\text { A one-day general strike against } \\
\text { austerity measures cripples Greece's } \\
\text { transport and public services. }\end{array}$ & Greece & N/A & N/A & Greece & Greece \\
\hline
\end{tabular}




\begin{tabular}{|c|c|c|c|c|c|c|}
\hline date & Description & News Entity & $\begin{array}{c}\text { Total } \\
\text { Reported } \\
\text { Purchases }\end{array}$ & $\begin{array}{l}\text { News Entity } \\
\text { Estimated } \\
\text { Purchases }\end{array}$ & $\begin{array}{l}\text { SMP } \\
\text { Focus } \\
\text { Country }\end{array}$ & $\begin{array}{l}\text { Media } \\
\text { Focus } \\
\text { Country }\end{array}$ \\
\hline $2 / 25 / 10$ & $\begin{array}{l}\text { EU and IMF deliver a grim assessment } \\
\text { of Greece's finances }\end{array}$ & Greece & N/A & N/A & Greece & Greece \\
\hline $3 / 5 / 10$ & $\begin{array}{l}\text { Greece passes public sector pay cuts } \\
\text { and tax increases to save } € 4.8 \text { billion. }\end{array}$ & Greece & N/A & N/A & Greece & Greece \\
\hline $3 / 8 / 10$ & Portugal unveils an austerity plan. & Portugal & N/A & N/A & Greece & Greece \\
\hline $3 / 15 / 10$ & $\begin{array}{l}\text { EMU finance ministers agree to help } \\
\text { Greece; no details given. }\end{array}$ & Greece & N/A & N/A & Greece & Greece \\
\hline 3/18/10 & $\begin{array}{l}\text { Greece says it may have to go to the } \\
\text { IMF as it will not be able to cut its } \\
\text { deficit if borrowing costs remain high. }\end{array}$ & Greece & N/A & N/A & Greece & Greece \\
\hline 3/19/10 & $\begin{array}{l}\text { EC President asks EU-member states to } \\
\text { be ready to offer bilateral loans and an } \\
\text { aid package to Greece. }\end{array}$ & Greece & N/A & N/A & Greece & Greece \\
\hline $3 / 24 / 10$ & $\begin{array}{l}\text { Fitch ratings cuts Portugal's credit } \\
\text { rating to AA }\end{array}$ & Portugal & N/A & N/A & Greece & Greece \\
\hline $3 / 25 / 10$ & $\begin{array}{l}\text { ECB says it will soften rules on } \\
\text { collateral for its loans, easing risk of } \\
\text { Greek institutions being cut off from } \\
\text { funding. Eurozone leaders agree to } \\
\text { create joint financial safety net, with } \\
\text { IMF, to help Greece and to restore } \\
\text { confidence in euro. }\end{array}$ & Greece & N/A & N/A & Greece & Greece \\
\hline $3 / 25 / 10$ & $\begin{array}{l}\text { Ireland reported its GDP fell by a record } \\
7.1 \text { percent in 2009, in which it adopted } \\
\text { two austerity plans. }\end{array}$ & Ireland & N/A & N/A & Greece & Greece \\
\hline 3/31/10 & $\begin{array}{c}\text { Anglo Irish Bank reports the biggest } \\
\text { corporate loss in Irish history - €12.7 } \\
\text { billion. }\end{array}$ & Ireland & N/A & N/A & Greece & Greece \\
\hline $4 / 11 / 10$ & $\begin{array}{l}\text { EU leaders approve } € 30 \text { billion in } \\
\text { emergency aid at a rate of five percent } \\
\text { for Greece; the country still must } \\
\text { activate it. }\end{array}$ & Greece & N/A & N/A & Greece & Greece \\
\hline $4 / 13 / 10$ & $\begin{array}{l}\text { The ECB voices its support for the } \\
\text { Greek rescue plan. }\end{array}$ & Greece & N/A & N/A & Greece & Greece \\
\hline 4/15/10 & $\begin{array}{l}\text { Greece passes law to tackle tax evasion } \\
\text { and shift tax burdens to higher earners. }\end{array}$ & Greece & N/A & N/A & Greece & Greece \\
\hline $4 / 21 / 10$ & $\begin{array}{l}\text { Investors dump Greek assets on rescue } \\
\text { fund uncertainly. The } 10 \text {-year Greek } \\
\text { government bond reaches } 8.4 \text { percent. }\end{array}$ & Greece & N/A & N/A & Greece & Greece \\
\hline
\end{tabular}




\begin{tabular}{|c|c|c|c|c|c|c|}
\hline date & Description & News Entity & $\begin{array}{l}\text { Total } \\
\text { Reported } \\
\text { Purchases }\end{array}$ & $\begin{array}{l}\text { News Entity } \\
\text { Estimated } \\
\text { Purchases }\end{array}$ & $\begin{array}{l}\text { SMP } \\
\text { Focus } \\
\text { Country }\end{array}$ & $\begin{array}{l}\text { Media } \\
\text { Focus } \\
\text { Country }\end{array}$ \\
\hline $4 / 22 / 10$ & $\begin{array}{c}\text { Eurostat says Greece's } 2009 \text { budget } \\
\text { deficit was } 13.6 \text { percent of GDP, not } \\
12.7 \text { percent as reported earlier. Moody's } \\
\text { cuts Greece's sovereign rating a notch to } \\
\text { A3, sparking market panic. }\end{array}$ & Greece & N/A & N/A & Greece & Greece \\
\hline $4 / 23 / 10$ & $\begin{array}{l}\text { Greece activates an EU/IMF aid } \\
\text { package for up to } € 45 \text { billion. }\end{array}$ & Greece & N/A & N/A & Greece & Greece \\
\hline $4 / 27 / 10$ & $\begin{array}{c}\text { Standard \& Poor's downgrades Greece's } \\
\text { credit rating to junk status and } \\
\text { Portuguese debt two notches with a } \\
\text { negative outlook. European equities } \\
\text { tumble. }\end{array}$ & Greece & N/A & N/A & Greece & Greece \\
\hline $4 / 28 / 10$ & $\begin{array}{c}\text { Standard \& Poor's downgrades Spanish } \\
\text { bonds to AA }\end{array}$ & Spain & N/A & N/A & Greece & Greece \\
\hline $5 / 1 / 10$ & $\begin{array}{l}\text { German Chancellor Merkel says } \\
\text { Germany's private sector will contribute } \\
\text { to Greek rescue package. }\end{array}$ & Greece & N/A & N/A & Greece & Greece \\
\hline $5 / 2 / 10$ & $\begin{array}{l}\text { Greece and the EU and IMF finalize a } \\
\text { deal of a } € 110 \text { billion euro bailout for } \\
\text { extra budget cuts of } € 30 \text { billion over } \\
\text { three years. Germany approves a } € 22.4 \\
\text { billion share. }\end{array}$ & Greece & N/A & N/A & Greece & Greece \\
\hline $5 / 3 / 10$ & $\begin{array}{l}\text { The ECB announces it will accept } \\
\text { Greek bonds as collateral even if their } \\
\text { rating falls below the BBB floor. }\end{array}$ & Greece & N/A & N/A & Greece & Greece \\
\hline $\begin{array}{l}5 / 4 / 2010 \\
- \\
5 / 5 / 2010\end{array}$ & $\begin{array}{c}\text { Up to 50,000 Greek public-sector } \\
\text { workers stage a 48-hour strike in } \\
\text { Athens, and hundreds fight with police. } \\
\text { On May 5th, three people are killed } \\
\text { when a bank is set on fire. }\end{array}$ & Greece & N/A & N/A & Greece & Greece \\
\hline $5 / 5 / 10$ & $\begin{array}{l}\text { Spain and the IMF firmly dismiss } \\
\text { market speculation that Madrid is } \\
\text { seeking a massive loan. }\end{array}$ & Spain & N/A & N/A & Greece & Greece \\
\hline $5 / 6 / 10$ & $\begin{array}{l}\text { Greece approves latest austerity bill. } \\
\text { Around 10,000 converge on Greek } \\
\text { parliament; the euro reaches its lowest } \\
\text { point since March 2009; and the Dow } \\
\text { index suffers a record one-day drop of } \\
\text { almost 1,000 points. }\end{array}$ & Greece & N/A & N/A & Greece & Greece \\
\hline $5 / 7 / 10$ & $\begin{array}{l}\text { Eurozone leaders meet at a summit to } \\
\text { stem the Greek crisis and stop its spread. }\end{array}$ & Greece & N/A & N/A & Greece & Greece \\
\hline
\end{tabular}




\begin{tabular}{|c|c|c|c|c|c|c|}
\hline date & Description & News Entity & $\begin{array}{c}\text { Total } \\
\text { Reported } \\
\text { Purchases } \\
\end{array}$ & $\begin{array}{l}\text { News Entity } \\
\text { Estimated } \\
\text { Purchases }\end{array}$ & $\begin{array}{l}\text { SMP } \\
\text { Focus } \\
\text { Country }\end{array}$ & $\begin{array}{l}\text { Media } \\
\text { Focus } \\
\text { Country }\end{array}$ \\
\hline $5 / 9 / 10$ & $\begin{array}{l}\text { The IMF unanimously approves its part } \\
\text { of the Greek rescue; } € 5.5 \text { billion } \\
\text { provided immediately. Germany's ruling } \\
\text { coalition loses its majority in the upper } \\
\text { house for aiding Greece. The EU’s } \$ 1 \\
\text { trillion temporary bail-out mechanism, } \\
\text { the European Financial Stability Facility } \\
\text { (EFSF) is set up by the EU and IMF. }\end{array}$ & Greece & N/A & N/A & Greece & Greece \\
\hline $5 / 10 / 10$ & $\begin{array}{l}\text { The ECB announces the Securities } \\
\text { Market Programme (SMP). All } 16 \\
\text { Eurozone central banks purchase } \\
\text { sovereign bonds. Peripheral yields fall } \\
\text { across peripheral Europe. Greek equities } \\
\text { rise by more than } 7.5 \text { percent. }\end{array}$ & $\begin{array}{c}\text { Greece } \\
\text { Portugal } \\
\text { Ireland } \\
\text { Spain Italy }\end{array}$ & 16.30 & $\begin{array}{l}8.97 \\
4.08 \\
3.26 \\
0.00 \\
0.00\end{array}$ & Greece & Greece \\
\hline $5 / 11 / 10$ & $\begin{array}{l}\text { Germany's cabinet approves the biggest } \\
\text { national contribution - } € 123 \text { billion in } \\
\text { loan guarantees - to the EFSF. }\end{array}$ & Greece & 16.30 & 8.97 & Greece & Greece \\
\hline $5 / 13 / 10$ & $\begin{array}{l}\text { Portugal proposes steps to slash its } \\
\text { deficit to } 7.3 \text { percent of GDP in } 2010 \\
\text { and } 4.6 \text { percent in } 2011 .\end{array}$ & Portugal & 16.30 & 3.26 & Greece & Greece \\
\hline $5 / 17 / 10$ & $\begin{array}{l}\text { The ECB is seen buying Irish } \\
\text { government bonds. }\end{array}$ & Ireland & 10.40 & 2.60 & Greece & Greece \\
\hline $5 / 18 / 10$ & $\begin{array}{l}\text { Greece receives its first bail-out loan for } \\
€ 14.5 \text { billion to repay its immediate } \\
\text { debt, easing market jitters. The ECB } \\
\text { buys Irish sovereign debt on the } \\
\text { secondary market. EU leaders meet to } \\
\text { fine-tune the EFSF. Germany bans } \\
\text { some types of short selling. }\end{array}$ & $\begin{array}{l}\text { Greece } \\
\text { Ireland }\end{array}$ & 10.40 & $\begin{array}{l}5.72 \\
2.60\end{array}$ & Greece & Greece \\
\hline $5 / 19 / 10$ & $\begin{array}{l}\text { Germany's surprise short-selling ban } \\
\text { lowers confidence in the Eurozone, } \\
\text { sending Greek yields up } 96 \text { basis points. }\end{array}$ & Greece & 10.40 & 8.97 & Greece & Greece \\
\hline $5 / 25 / 10$ & $\begin{array}{l}\text { Italy's cabinet approves an austerity } \\
\text { package to cut the deficit by } € 24 \text { billion } \\
\text { in } 2011 \text { and } 2012 \text { with the aim of } \\
\text { lowering it from } 5.3 \text { to } 2.7 \text { percent of } \\
\text { GDP by } 2012 \text {. }\end{array}$ & Italy & 8.80 & 0 & Greece & Greece \\
\hline $5 / 27 / 10$ & $\begin{array}{l}\text { Spain approves an austerity package of } \\
\text { about } 1.5 \text { percent of GDP by one vote. } \\
\text { The Bank of Spain seizes CajaSur, } \\
\text { beginning the consolidation of the } \\
\text { banking system. The ECB buys bonds in } \\
\text { small quantities, reducing volatility after } \\
\text { a report that China was reviewing its } \\
\text { holdings of European debt. }\end{array}$ & Spain & 8.80 & 0 & Greece & Greece \\
\hline
\end{tabular}




\begin{tabular}{|c|c|c|c|c|c|c|}
\hline date & Description & News Entity & $\begin{array}{c}\text { Total } \\
\text { Reported } \\
\text { Purchases }\end{array}$ & $\begin{array}{l}\text { News Entity } \\
\text { Estimated } \\
\text { Purchases }\end{array}$ & $\begin{array}{l}\text { SMP } \\
\text { Focus } \\
\text { Country }\end{array}$ & $\begin{array}{l}\text { Media } \\
\text { Focus } \\
\text { Country }\end{array}$ \\
\hline $5 / 29 / 10$ & $\begin{array}{l}\text { Fitch Ratings downgrades Spanish } \\
\text { bonds one notch to AA+. }\end{array}$ & Spain & 4.90 & 0 & Greece & Greece \\
\hline $6 / 4 / 10$ & $\begin{array}{c}\text { Below-forecast U.S. jobs data and } \\
\text { scaled-back SMP purchases widen } \\
\text { peripheral European yield spreads. } \\
\text { National central banks resume buying } \\
\text { Greek 2- to 10-year paper in the } \\
\text { afternoon. }\end{array}$ & Greece & 4.90 & 5.36 & Greece & Greece \\
\hline $6 / 8 / 10$ & $\begin{array}{l}\text { Greece's consumer inflation jumps to } \\
5.4 \text { percent in May, its highest since } \\
\text { August } 1997 \text {. The cost of Insuring most } \\
\text { European government debt against } \\
\text { default rises sharply, notably for } \\
\text { Portugal and Belgium. Analysts at } \\
\text { Danske Bank call on the ECB to step up } \\
\text { use of the SMP. Spain's unions claim } 75 \\
\text { percent of public sector workers stay at } \\
\text { home in a protest against austerity plans. } \\
\text { Government says real number is far } \\
\text { smaller. }\end{array}$ & $\begin{array}{l}\text { Greece } \\
\text { Portugal } \\
\text { Belgium } \\
\text { Spain }\end{array}$ & 6.70 & $\begin{array}{l}5.36 \\
0.67 \\
0.00 \\
0.00\end{array}$ & Greece & Greece \\
\hline $6 / 9 / 10$ & $\begin{array}{l}\text { Portuguese parliament approves an } \\
\text { austerity package and rules out drawing } \\
\text { on the Eurozone aid package, citing a } \\
\text { successful bond sale and signs of } \\
\text { economic recovery in quarter } 1 \text {. }\end{array}$ & Portugal & 6.70 & 0.67 & Greece & Greece \\
\hline $6 / 10 / 10$ & $\begin{array}{l}\text { Negotiations to overhaul Spain's labor } \\
\text { market collapse, leaving the government } \\
\text { to impose looser hire and fire laws } \\
\text { without trade union backing }\end{array}$ & Spain & 6.70 & 0.00 & Greece & Greece \\
\hline $6 / 11 / 10$ & $\begin{array}{l}\text { Greece vows it won't default on its } \\
\text { loans. Austerity is intended "to exclude } \\
\text { default and to exclude exit from the } \\
\text { Eurozone" declares the prime minister. }\end{array}$ & Greece & 6.70 & 5.36 & Greece & Greece \\
\hline $6 / 14 / 10$ & $\begin{array}{l}\text { Moody's cuts Greece's credit rating four } \\
\text { notches to Ba1, or junk status, over risks } \\
\text { to an EU/IMF bailout package. Greece } \\
\text { says Moody's cut is not justified. }\end{array}$ & Greece & 4.00 & 3.20 & Greece & Greece \\
\hline
\end{tabular}




\begin{tabular}{|c|c|c|c|c|c|c|}
\hline date & Description & News Entity & $\begin{array}{c}\text { Total } \\
\text { Reported } \\
\text { Purchases }\end{array}$ & $\begin{array}{l}\text { News Entity } \\
\text { Estimated } \\
\text { Purchases }\end{array}$ & $\begin{array}{l}\text { SMP } \\
\text { Focus } \\
\text { Country }\end{array}$ & $\begin{array}{l}\text { Media } \\
\text { Focus } \\
\text { Country }\end{array}$ \\
\hline 6/15/10 & $\begin{array}{l}\text { ECB says it will apply a } 5 \text { percent extra } \\
\text { charge to Greek government bonds used } \\
\text { as collateral in lending operations } \\
\text { following Moody's downgrade. An } \\
\text { Irish debt auction attracts strong demand } \\
\text { from investors attracted by higher } \\
\text { yields. In response, Ireland decides to } \\
\text { continue monthly bond auctions. The } \\
\text { ECB was buys Irish bonds in the run-up } \\
\text { to the auction. }\end{array}$ & $\begin{array}{l}\text { Greece } \\
\text { Ireland }\end{array}$ & 4.00 & $\begin{array}{l}3.20 \\
0.40\end{array}$ & Greece & Greece \\
\hline 6/17/10 & $\begin{array}{l}\text { ECB board member says the SMP will } \\
\text { continue to buy government bonds until } \\
\text { markets have sufficiently stabilized. } \\
\text { European leaders agree to publish details } \\
\text { of "stress tests" showing the financial } \\
\text { health of individual banks in July and to } \\
\text { toughen budget rules. }\end{array}$ & $\begin{array}{c}\text { ECB } \\
\text { EU }\end{array}$ & 4.00 & N/A & Greece & Greece \\
\hline 6/17/10 & $\begin{array}{l}\text { Successful Spanish bond auction after } \\
\text { the Bank of Spain released reassuring } \\
\text { bank stress test results. }\end{array}$ & Spain & 4.00 & 0.00 & Greece & Greece \\
\hline $6 / 22 / 10$ & $\begin{array}{l}\text { Spain's parliament ratifies labor reforms } \\
\text { to restore economic growth by easing } \\
\text { the cost of hiring and firing. }\end{array}$ & Spain & 4.20 & 0.00 & Greece & Greece \\
\hline $6 / 24 / 10$ & $\begin{array}{l}\text { The cost of insuring against sovereign } \\
\text { default in Greece hits a record high. } \\
\text { Spain's parliament ratifies labor reforms } \\
\text { aimed at restoring long-term economic } \\
\text { growth by easing the cost of hiring and } \\
\text { firing. }\end{array}$ & Greece & 4.20 & 3.36 & Greece & Greece \\
\hline $6 / 25 / 10$ & $\begin{array}{l}\text { The CGIL, Italy's largest union, holds } \\
\text { rallies in Rome, Milan and other cities to } \\
\text { force the government to redraft a } € 25 \\
\text { billion austerity package. }\end{array}$ & Italy & 4.20 & 0.00 & Greece & Greece \\
\hline 6/29/10 & $\begin{array}{l}\text { About } 10,000 \text { people take part in } \\
\text { marches across Athens against austerity } \\
\text { measures. Greece reports that its debt } \\
\text { reached } 133 \text { percent of GDP in } 2010 \text {. }\end{array}$ & Greece & 3.70 & 2.96 & Greece & Greece \\
\hline
\end{tabular}




\begin{tabular}{|c|c|c|c|c|c|c|}
\hline date & Description & News Entity & $\begin{array}{c}\text { Total } \\
\text { Reported } \\
\text { Purchases }\end{array}$ & $\begin{array}{l}\text { News Entity } \\
\text { Estimated } \\
\text { Purchases }\end{array}$ & $\begin{array}{l}\text { SMP } \\
\text { Focus } \\
\text { Country }\end{array}$ & $\begin{array}{l}\text { Media } \\
\text { Focus } \\
\text { Country }\end{array}$ \\
\hline 6/30/10 & $\begin{array}{l}\text { The ECB's Covered Bond Purchase } \\
\text { Programme ends. The ECB had } \\
\text { purchased just over €60 billion covered } \\
\text { bonds on the primary and secondary } \\
\text { markets. }\end{array}$ & ECB & 3.70 & N/A & Greece & Greece \\
\hline $7 / 1 / 10$ & $\begin{array}{l}\text { the ECB renews its one-year liquidity } \\
\text { operations for banks, relieving fear of a } \\
\text { credit crunch should the banks be forced } \\
\text { to repay at this time. }\end{array}$ & ECB & 3.70 & N/A & Greece & Greece \\
\hline $7 / 7 / 10$ & $\begin{array}{l}\text { Greece passes pension reform - a key } \\
\text { requirement of the EU/IMF deal. Private } \\
\text { and public sector unions strike for } 24 \\
\text { hours. }\end{array}$ & Greece & 0.80 & 0.76 & Greece & Greece \\
\hline $7 / 8 / 10$ & $\begin{array}{l}\text { ECB meeting. It left its key interest rate } \\
\text { unchanged. The ECB's absence from } \\
\text { secondary bond markets was noted. }\end{array}$ & ECB & 0.80 & & Greece & Greece \\
\hline $7 / 13 / 10$ & $\begin{array}{l}\text { Moody's cuts Portugal's debt rating by } \\
\text { two notches to A1 and urges more } \\
\text { austerity measures in its } 2011 \text { budget. }\end{array}$ & Portugal & 0.30 & 0.00 & Greece & Greece \\
\hline $7 / 14 / 10$ & $\begin{array}{l}\text { Berlusconi wins a confidence vote on a } \\
€ 25 \text { billion austerity package deemed } \\
\text { crucial to protect Italy's financial } \\
\text { stability. }\end{array}$ & Italy & 0.30 & 0.00 & Greece & Greece \\
\hline 7/19/10 & $\begin{array}{l}\text { Moody's reduces Ireland's credit rating } \\
\text { by one notch to Aa2. }\end{array}$ & Ireland & 0.18 & 0.01 & Ireland & Ireland \\
\hline $7 / 23 / 10$ & $\begin{array}{l}\text { European banks are given "stress tests" } \\
\text { on their ability to deal with a debt crisis. } \\
\text { Of the } 91 \text { European banks tested, seven } \\
\text { fail and another } 17 \text { barely pass. Results } \\
\text { calm markets but later the tests' rigor is } \\
\text { questioned. }\end{array}$ & EU & 0.18 & & Ireland & Ireland \\
\hline $7 / 29 / 10$ & $\begin{array}{c}\text { Italy's } € 25 \text { billion euro package of } \\
\text { austerity measures is approved in the } \\
\text { lower house, clearing its final } \\
\text { parliamentary hurdle. }\end{array}$ & Italy & 0.08 & 0.00 & Greece & Ireland \\
\hline $7 / 29 / 10$ & $\begin{array}{l}\text { The European Commission's economic } \\
\text { sentiment index rises to a 28-month high } \\
\text { in July, buoyed by figures from } \\
\text { Germany. }\end{array}$ & EU & 0.08 & & Greece & Ireland \\
\hline
\end{tabular}




\begin{tabular}{|c|c|c|c|c|c|c|}
\hline date & Description & News Entity & $\begin{array}{c}\text { Total } \\
\text { Reported } \\
\text { Purchases }\end{array}$ & $\begin{array}{c}\text { News Entity } \\
\text { Estimated } \\
\text { Purchases }\end{array}$ & $\begin{array}{l}\text { SMP } \\
\text { Focus } \\
\text { Country }\end{array}$ & $\begin{array}{c}\text { Media } \\
\text { Focus } \\
\text { Country }\end{array}$ \\
\hline $8 / 5 / 10$ & $\begin{array}{l}\text { EU, IMF, and ECB officials applaud } \\
\text { Greek efforts to exit its debt crisis, } \\
\text { endorsing a fresh } € 9 \text { billion payment } \\
\text { from the EU/IMF bailout scheme, but } \\
\text { urging reforms in energy, banking, and } \\
\text { the public sector. }\end{array}$ & Greece & 0.01 & 0.01 & Greece & Ireland \\
\hline $8 / 6 / 10$ & $\begin{array}{l}\text { Speaking after a meeting in which the } \\
\text { ECB held rates at } 1 \text { percent, ECB } \\
\text { President Trichet sounded much more } \\
\text { upbeat on the economy than in recent } \\
\text { months. }\end{array}$ & ECB & 0.01 & & Greece & Ireland \\
\hline 8/10/10 & $\begin{array}{l}\text { Ireland receives approval to give another } \\
€ 10 \text { billion of capital to nationalized } \\
\text { lender Anglo Irish Bank, adding to } \\
€ 14.3 \text { billion already provided. Yields } \\
\text { rose on fears of bailouts to other Irish } \\
\text { banks. One dealer said he saw ECB bids } \\
\text { at the short-end of the Irish curve to help } \\
\text { support the market }\end{array}$ & Ireland & 0.01 & 0.00 & Greece & Ireland \\
\hline 8/11/10 & $\begin{array}{l}\text { Slovakia, the Eurozone's poorest } \\
\text { member rules out providing €816 } \\
\text { million towards a €110 billion Greek } \\
\text { bailout fund. Slovakia will contribute to } \\
\text { the wider safety net. }\end{array}$ & Greece & 0.01 & 0.01 & Greece & Ireland \\
\hline $8 / 12 / 10$ & $\begin{array}{l}\text { Ireland pays sharply higher yields on a } \\
\text { six-month note auction and the yield on } \\
\text { the Irish } 10 \text {-year bond rose significantly } \\
\text { over the week. Market sources reported } \\
\text { that the ECB bought short-dated Irish } \\
\text { government bonds from Aug. } 11 \text { - Aug. } \\
\text { 12. in a response to volatility in yields } \\
\text { amid low trading volumes. }\end{array}$ & Ireland & 0.01 & 0.00 & Greece & Ireland \\
\hline 8/16/10 & $\begin{array}{l}\text { In the secondary market, the gap } \\
\text { between Irish } 10 \text {-year bonds and } \\
\text { German bunds hit a three-month high of } \\
313 \text { basis points and the cost of } \\
\text { protecting against sovereign default hit a } \\
\text { 17-month high. The asset movements } \\
\text { were attributed to Ireland's larger than } \\
\text { expected capital injection for Anglo } \\
\text { Irish. The ECB had buys Irish debt to } \\
\text { help stabilize spreads. }\end{array}$ & Ireland & 0.34 & 0.02 & Greece & Ireland \\
\hline
\end{tabular}




\begin{tabular}{|c|c|c|c|c|c|c|}
\hline date & Description & News Entity & $\begin{array}{l}\text { Total } \\
\text { Reported } \\
\text { Purchases }\end{array}$ & $\begin{array}{l}\text { News Entity } \\
\text { Estimated } \\
\text { Purchases }\end{array}$ & $\begin{array}{l}\text { SMP } \\
\text { Focus } \\
\text { Country }\end{array}$ & $\begin{array}{l}\text { Media } \\
\text { Focus } \\
\text { Country }\end{array}$ \\
\hline $8 / 20 / 10$ & $\begin{array}{l}\text { The European Commission warns that in } \\
\text { order to slash its budget deficit to } 8.1 \\
\text { percent of GDP in 2010, Greece must } \\
\text { offset weaker-than-expected tax revenue } \\
\text { growth by keeping spending } € 4 \text { billion } \\
\text { below an original target. }\end{array}$ & Greece & 0.34 & 0.32 & Greece & Ireland \\
\hline $8 / 23 / 10$ & $\begin{array}{l}\text { Greece's debt agency says it will switch } \\
\text { from quarterly to monthly Treasury bill } \\
\text { auctions starting from September, giving } \\
\text { it more leeway to manage its short-term } \\
\text { debt but also revealing its difficulty in } \\
\text { funding itself from the market through } \\
\text { normal issues. }\end{array}$ & Greece & 0.14 & 0.13 & Ireland & Ireland \\
\hline $8 / 23 / 10$ & $\begin{array}{l}\text { The ECB purchases mainly of Irish } \\
\text { bonds. Nevertheless, the 10-year Irish } \\
\text { yield ends higher than the Spanish or } \\
\text { Portuguese equivalent. Standard \& } \\
\text { Poor's cuts Ireland's long-term rating by } \\
\text { one notch to 'AA-' with a negative } \\
\text { outlook, on fears of a higher bill for } \\
\text { supporting Anglo Irish and other banks. }\end{array}$ & Ireland & 0.14 & 0.01 & Ireland & Ireland \\
\hline $8 / 25 / 10$ & $\begin{array}{l}\text { Portugal sold more than its maximum } \\
\text { target at bond auction at marginally } \\
\text { higher yields. Economists warn that, } \\
\text { while Portugal has no payment duties } \\
\text { for the rest of 2010, its budget cutting is } \\
\text { not fully on track. Greece says its } \\
\text { economy will contract less than the } \\
\text { official } 4 \text { percent forecast this year. }\end{array}$ & $\begin{array}{c}\text { Portugal } \\
\text { Greece }\end{array}$ & 0.14 & $\begin{array}{l}0.13 \\
0.00\end{array}$ & Ireland & Ireland \\
\hline $8 / 27 / 10$ & $\begin{array}{l}\text { Despite Standard and Poor's Irish } \\
\text { downgrade, investors buy } € 600 \text { million } \\
\text { of short-term Irish debt at a lower } \\
\text { interest rate than at its last auction two } \\
\text { weeks prior. The ECB appeared to have } \\
\text { had no involvement in the auction. }\end{array}$ & Ireland & 0.14 & 0.01 & Ireland & Ireland \\
\hline $9 / 1 / 10$ & $\begin{array}{c}\text { The Portuguese Treasury sold } € 1.012 \\
\text { billion of 6- and 12-month treasury bills } \\
\text { at a higher yield. }\end{array}$ & Portugal & 0.17 & 0.00 & Greece & Ireland \\
\hline
\end{tabular}




\begin{tabular}{|c|c|c|c|c|c|c|}
\hline date & Description & News Entity & $\begin{array}{c}\text { Total } \\
\text { Reported } \\
\text { Purchases } \\
\end{array}$ & $\begin{array}{c}\text { News Entity } \\
\text { Estimated } \\
\text { Purchases }\end{array}$ & $\begin{array}{c}\text { SMP } \\
\text { Focus } \\
\text { Country }\end{array}$ & $\begin{array}{l}\text { Media } \\
\text { Focus } \\
\text { Country }\end{array}$ \\
\hline $9 / 2 / 10$ & $\begin{array}{l}\text { Spain holds a successful bond sale; } \\
\text { yields fell sharply from its previous } \\
\text { auction. One source claims a more than } \\
\text { a 50\% uptake among foreign investors. } \\
\text { The ECB holds rates at } 1 \text { percent and } \\
\text { extends its liquidity safety net for } \\
\text { vulnerable Eurozone banks. It } \\
\text { committed to provide unlimited 1-week } \\
\text { and 1-month funding until at least } \\
\text { January 18, } 2011 \text {. }\end{array}$ & Spain & 0.17 & 0.00 & Greece & Ireland \\
\hline $9 / 7 / 10$ & $\begin{array}{l}\text { The WSJ reports that bank stress tests } \\
\text { published in July had understated some } \\
\text { European lenders' holdings of } \\
\text { potentially risky government debt. The } \\
\text { report causes Bund futures to rise and } \\
\text { Irish and Portuguese yields to spike. } \\
\text { Greece announces a cabinet reshuffle, } \\
\text { less than a year after the current } \\
\text { government came to power. EU leaders } \\
\text { approve the second €6.5 billion bailout } \\
\text { installment for Greece. }\end{array}$ & $\begin{array}{l}\text { Portugal } \\
\text { Ireland } \\
\text { Greece }\end{array}$ & 0.24 & $\begin{array}{l}0.05 \\
0.14 \\
0.05\end{array}$ & Portugal & Ireland \\
\hline $9 / 9 / 10$ & $\begin{array}{l}\text { Peripheral bond yield spreads tighten } \\
\text { following a smooth sale of Irish short- } \\
\text { term Treasury bills. Market participants } \\
\text { report the ECB was active in the Irish } \\
\text { secondary market. }\end{array}$ & Ireland & 1.54 & 0.92 & Portugal & Ireland \\
\hline $9 / 10 / 10$ & $\begin{array}{c}\text { The IMF says Greece is ahead of } \\
\text { schedule in economic reform and it will } \\
\text { disburse an additional } € 2.57 \text { billion } \\
\text { under a standby loan. }\end{array}$ & Greece & 0.24 & 0.05 & Portugal & Ireland \\
\hline $9 / 17 / 10$ & $\begin{array}{l}\text { The Irish/German spread widens and the } \\
\text { cost of insuring Irish five-year debt } \\
\text { rises, both to a euro-era peak, after a } \\
\text { press report which suggests Ireland } \\
\text { might need emergency funds. Traders } \\
\text { say the ECB had either bought or asked } \\
\text { for quotes on } € 5 \text { million of Irish bonds. }\end{array}$ & Ireland & 0.32 & 0.19 & Ireland & Ireland \\
\hline $9 / 21 / 10$ & $\begin{array}{c}\text { Irish bond yields climb to } 6.5 \text { percent } \\
\text { ahead of a debt auction on concerns of } \\
\text { the cost of Ireland's bank rescues. The } \\
\text { ECB refuses to comment on reports that } \\
\text { it bought Irish bonds on the secondary } \\
\text { market. }\end{array}$ & Ireland & 0.13 & 0.08 & Ireland & Ireland \\
\hline
\end{tabular}




\begin{tabular}{|c|c|c|c|c|c|c|}
\hline date & Description & News Entity & $\begin{array}{l}\text { Total } \\
\text { Reported } \\
\text { Purchases } \\
\end{array}$ & $\begin{array}{l}\text { News Entity } \\
\text { Estimated } \\
\text { Purchases }\end{array}$ & $\begin{array}{l}\text { SMP } \\
\text { Focus } \\
\text { Country }\end{array}$ & $\begin{array}{l}\text { Media } \\
\text { Focus } \\
\text { Country }\end{array}$ \\
\hline $9 / 22 / 10$ & $\begin{array}{l}\text { Portugal sells the minimum amount } \\
\text { targeted in 5-year sovereign debt at a } \\
\text { significant premium over its previous 5- } \\
\text { year auction in July. }\end{array}$ & Portugal & 0.13 & 0.03 & Ireland & Ireland \\
\hline 9/27/10 & $\begin{array}{l}\text { Moody's slashes Anglo Irish's debt } \\
\text { ratings. The euro falls steeply. }\end{array}$ & Ireland & 1.54 & 0.92 & Ireland & Ireland \\
\hline $9 / 28 / 10$ & $\begin{array}{l}\text { Standard \& Poor's and Fitch Ratings } \\
\text { warn Ireland is at risk of further } \\
\text { downgrades, triggering a leap in } \\
\text { borrowing costs to another record high. } \\
\text { The ECB buys Irish debt. The ECB } \\
\text { purchases focused on securities with } \\
\text { maturities of as long as five years. Spain } \\
\text { presents a tough } 2011 \text { budget, deepening } \\
\text { an austerity drive and taxing the rich } \\
\text { more heavily. }\end{array}$ & $\begin{array}{l}\text { Ireland } \\
\text { Spain }\end{array}$ & 1.54 & $\begin{array}{l}0.92 \\
0.00\end{array}$ & Ireland & Ireland \\
\hline 9/29/10 & $\begin{array}{l}\text { Portugal announces new austerity for } \\
\text { 2011. Thousands protest across Europe } \\
\text { against government austerity. The } \\
\text { European Commission proposes repeat } \\
\text { deficit offenders deposit } 0.2 \text { percent of } \\
\text { their GDP with Brussels. }\end{array}$ & Portugal & 1.54 & 0.31 & Ireland & Ireland \\
\hline 9/30/10 & $\begin{array}{l}\text { Ireland's central bank reveals the cost of } \\
\text { rescuing the banking sector will push the } \\
\text { public deficit to } 32 \text { percent of GDP in } \\
\text { 2010. The government promises a four- } \\
\text { year austerity plan to bring the deficit } \\
\text { back under } 3 \text { percent by 2014. Spain } \\
\text { loses its final AAA credit rating when } \\
\text { Moody's cuts it by one notch. Spain } \\
\text { presents a budget to parliament that cuts } \\
\text { its net debt issuance in } 2011 \text {. }\end{array}$ & $\begin{array}{l}\text { Ireland } \\
\text { Spain }\end{array}$ & 1.54 & $\begin{array}{l}0.92 \\
0.00\end{array}$ & Ireland & Ireland \\
\hline $10 / 4 / 10$ & $\begin{array}{l}\text { The Greek } 2011 \text { budget draft pledges to } \\
\text { cut the } 2011 \text { budget deficit to below a } \\
7.6 \text { percent-of-GDP target faster than } \\
\text { agreed in the IMF/EU bailout deal. } \\
\text { (October 3, after market close) }\end{array}$ & Greece & 0.09 & 0.02 & Ireland & Ireland \\
\hline $10 / 6 / 10$ & $\begin{array}{l}\text { Fitch cuts Ireland's credit rating to A+ } \\
\text { from AA-, with a negative outlook. The } \\
\text { ECB buys peripheral debt to combat } \\
\text { renewed financial turmoil. }\end{array}$ & Ireland & 0.09 & 0.07 & Ireland & Ireland \\
\hline
\end{tabular}




\begin{tabular}{|c|c|c|c|c|c|c|}
\hline date & Description & News Entity & $\begin{array}{c}\text { Total } \\
\text { Reported } \\
\text { Purchases }\end{array}$ & $\begin{array}{c}\text { News Entity } \\
\text { Estimated } \\
\text { Purchases }\end{array}$ & $\begin{array}{c}\text { SMP } \\
\text { Focus } \\
\text { Country }\end{array}$ & $\begin{array}{c}\text { Media } \\
\text { Focus } \\
\text { Country }\end{array}$ \\
\hline $10 / 19 / 10$ & $\begin{array}{l}\text { European leaders agree to reopen the } \\
\text { Lisbon Treaty to create a permanent } \\
\text { Eurozone rescue mechanism with debt } \\
\text { restructuring powers which may involve } \\
\text { private sector bond losses. Although } \\
\text { they specified that it would not apply to } \\
\text { existing bonds, markets interpreted the } \\
\text { proposal negatively. }\end{array}$ & EU & 0.00 & N/A & Ireland & Ireland \\
\hline $10 / 31 / 10$ & $\begin{array}{l}\text { Germany's ruling coalition, trailing in } \\
\text { polls and facing elections in 2011, backs } \\
\text { proposals to make bondholders } \\
\text { contribute to future euro-area bailouts. }\end{array}$ & EU & 0.71 & N/A & Ireland & Ireland \\
\hline $11 / 2 / 10$ & $\begin{array}{c}\text { The Greek prime minister threatens to } \\
\text { call early general elections if voters do } \\
\text { not back his austerity policies in local } \\
\text { polls on November } 6 \text {. }\end{array}$ & Greece & 0.71 & 0.14 & Ireland & Ireland \\
\hline $11 / 3 / 10$ & $\begin{array}{l}\text { Irish } 10 \text {-year bonds lead peripheral debt } \\
\text { underperformance, with the yield hitting } \\
\text { a euro-era high despite reports that the } \\
\text { ECB bought Irish paper over the past } \\
\text { two days. }\end{array}$ & Ireland & 0.71 & 0.57 & Ireland & Ireland \\
\hline $11 / 4 / 10$ & $\begin{array}{l}\text { Portugal passes the most severe budget } \\
\text { since it democratized. Its yields rise after } \\
\text { the announcement on fears it will not be } \\
\text { sufficient to cut the deficit to } 4.6 \text { percent } \\
\text { of GDP in } 2011 \text {. The ECB intervenes in } \\
\text { the secondary market several times, } \\
\text { buying more Dublin-issued paper, but to } \\
\text { little apparent avail. }\end{array}$ & $\begin{array}{l}\text { Portugal } \\
\text { Ireland }\end{array}$ & 0.71 & $\begin{array}{l}0.00 \\
0.57\end{array}$ & Ireland & Ireland \\
\hline $11 / 7 / 10$ & $\begin{array}{l}\text { Greek polls give the Greek government } \\
\text { a mandate to push through austerity } \\
\text { plans and so national elections are not } \\
\text { called. A press report claims Ireland } \\
\text { will not be able to raise funding } \\
\text { internationally in } 2011 .\end{array}$ & $\begin{array}{l}\text { Greece } \\
\text { Ireland }\end{array}$ & 1.10 & $\begin{array}{l}0.11 \\
0.43\end{array}$ & Portugal & $\begin{array}{l}\text { Portugal, } \\
\text { Ireland }\end{array}$ \\
\hline $11 / 8 / 10$ & $\begin{array}{l}\text { Fitch Ratings cut the credit ratings of } \\
\text { four Portuguese banks. Portugal's } \\
\text { sovereign debt difficulties have virtually } \\
\text { cut off its banks' access to capital } \\
\text { markets, forcing them to rely on funding } \\
\text { from the ECB. }\end{array}$ & Portugal & 1.10 & 0.54 & Portugal & $\begin{array}{c}\text { Portugal, } \\
\text { Ireland }\end{array}$ \\
\hline
\end{tabular}




\begin{tabular}{|c|c|c|c|c|c|c|}
\hline date & Description & News Entity & $\begin{array}{c}\text { Total } \\
\text { Reported } \\
\text { Purchases }\end{array}$ & $\begin{array}{c}\text { News Entity } \\
\text { Estimated } \\
\text { Purchases }\end{array}$ & $\begin{array}{c}\text { SMP } \\
\text { Focus } \\
\text { Country }\end{array}$ & $\begin{array}{c}\text { Media } \\
\text { Focus } \\
\text { Country }\end{array}$ \\
\hline $11 / 10 / 10$ & $\begin{array}{l}\text { Europe's largest clearing house, } \\
\text { LCH.Clearnet, increases the margin it } \\
\text { demands for Irish sovereign and bank } \\
\text { debt by } 15 \text { percent. The Irish opposition } \\
\text { party announces it will not back the } \\
2011 \text { austerity budget to be voted on in a } \\
\text { week. Portugal pays sharply higher } \\
\text { yields at its last } 2010 \text { bond auction but } \\
\text { sells nearly the maximum planned debt. }\end{array}$ & $\begin{array}{l}\text { Ireland } \\
\text { Portugal }\end{array}$ & 1.10 & $\begin{array}{l}0.43 \\
0.54\end{array}$ & Portugal & $\begin{array}{l}\text { Portugal, } \\
\text { Ireland }\end{array}$ \\
\hline $11 / 11 / 10$ & $\begin{array}{l}\text { Peripheral yields rise on expectations } \\
\text { Ireland will require aid. The } 10 \text {-year } \\
\text { Portuguese and Irish yield spreads over } \\
\text { German Bunds widen to new euro-era } \\
\text { highs but retract after reports the ECB } \\
\text { had bought } € 5 \text { million to } € 10 \text { million of } \\
\text { Irish and Portuguese bonds. }\end{array}$ & $\begin{array}{l}\text { Ireland } \\
\text { Portugal }\end{array}$ & 1.10 & $\begin{array}{l}0.43 \\
0.54\end{array}$ & Portugal & $\begin{array}{l}\text { Portugal, } \\
\text { Ireland }\end{array}$ \\
\hline $11 / 12 / 10$ & $\begin{array}{l}\text { Ireland publically denies rumors that it } \\
\text { has asked the EU for financial help, } \\
\text { claiming it is well funded until } \\
\text { mid } 2011 .\end{array}$ & Ireland & 1.10 & 0.43 & Portugal & $\begin{array}{c}\text { Portugal, } \\
\text { Ireland }\end{array}$ \\
\hline $11 / 13 / 10$ & $\begin{array}{l}\text { The potential for an interest holiday } \\
\text { triggers selling of Irish debt. The 10- } \\
\text { year Irish/German sovereign spread } \\
\text { surges to a record } 652 \text { basis points. }\end{array}$ & Ireland & 0.67 & 0.27 & Portugal & $\begin{array}{c}\text { Portugal, } \\
\text { Ireland }\end{array}$ \\
\hline $11 / 15 / 10$ & $\begin{array}{l}\text { Eurostat revises upwards Greece's } 2009 \\
\text { deficit for a third time, to } 15.4 \text { percent of } \\
\text { GDP. Greece says it will still bring the } \\
\text { shortfall below the Eurozone's } 3 \text { percent } \\
\text { of GDP ceiling by 2014, starting with a } \\
\text { 6-point cut in 2010. EU and IMF } \\
\text { officials arrive in Athens to inspect the } \\
\text { country's finances. Ireland admits it is in } \\
\text { contact with "international colleagues" } \\
\text { but denies making a bailout request. } \\
\text { Peripheral Eurozone yields fall as } \\
\text { investor belief grows that Ireland is } \\
\text { close to a bailout. }\end{array}$ & $\begin{array}{l}\text { Greece } \\
\text { Ireland }\end{array}$ & 0.67 & $\begin{array}{l}0.07 \\
0.27\end{array}$ & Portugal & $\begin{array}{c}\text { Portugal, } \\
\text { Ireland }\end{array}$ \\
\hline $11 / 16 / 10$ & $\begin{array}{l}\text { Ireland begins bailout talks with the } \\
\text { EU which announces readiness to } \\
\text { support the Irish banking sector if } \\
\text { necessary. Greek and Portuguese yields } \\
\text { rise. The ECB buys Irish debt on the } \\
\text { secondary market for a second day. }\end{array}$ & Ireland & 0.67 & 0.27 & Portugal & $\begin{array}{c}\text { Portugal, } \\
\text { Ireland }\end{array}$ \\
\hline
\end{tabular}




\begin{tabular}{|c|c|c|c|c|c|c|}
\hline date & Description & News Entity & $\begin{array}{c}\text { Total } \\
\text { Reported } \\
\text { Purchases }\end{array}$ & $\begin{array}{c}\text { News Entity } \\
\text { Estimated } \\
\text { Purchases }\end{array}$ & $\begin{array}{l}\text { SMP } \\
\text { Focus } \\
\text { Country }\end{array}$ & $\begin{array}{c}\text { Media } \\
\text { Focus } \\
\text { Country }\end{array}$ \\
\hline $11 / 17 / 10$ & $\begin{array}{l}\text { Influential blog Coulisses de Bruxelles } \\
\text { claims the ECB stopped buying Irish } \\
\text { debt to highlight its unhappiness with } \\
\text { Ireland's dependence on its emergency } \\
\text { funding. Austria's finance minister says } \\
\text { the EU postponed Greece's latest bailout } \\
\text { payment to check on its fiscal progress. } \\
\text { Delay concerns hurt periphery bonds, } \\
\text { Greek stocks. }\end{array}$ & $\begin{array}{l}\text { Ireland } \\
\text { Greece }\end{array}$ & 0.67 & $\begin{array}{l}0.27 \\
0.07\end{array}$ & Portugal & $\begin{array}{c}\text { Portugal, } \\
\text { Ireland }\end{array}$ \\
\hline $11 / 18 / 10$ & $\begin{array}{l}\text { Experts from the EU and the IMF arrive } \\
\text { in Ireland to assess its need for a bailout. } \\
\text { Ireland insists its low corporate tax is } \\
\text { non-negotiable. Spain holds a well- } \\
\text { received long-term bond auction but } \\
\text { pays higher yields than two months ago. }\end{array}$ & $\begin{array}{l}\text { Ireland } \\
\text { Spain }\end{array}$ & 0.67 & $\begin{array}{l}0.27 \\
0.00\end{array}$ & Portugal & $\begin{array}{c}\text { Portugal, } \\
\text { Ireland }\end{array}$ \\
\hline $11 / 21 / 10$ & $\begin{array}{l}\text { The EU and the IMF agree to a } € 80 \text { - } \\
€ 90 \text { billion loan for Ireland. EU leaders } \\
\text { expected Ireland's formal application for } \\
\text { aid would lower Portuguese and Spanish } \\
\text { yields but market response is lukewarm. }\end{array}$ & Ireland & 1.35 & 0.54 & Portugal & Ireland \\
\hline $11 / 23 / 10$ & $\begin{array}{l}\text { The junior partner in Ireland's coalition } \\
\text { government unexpectedly calls for } \\
\text { elections in a midday news program and } \\
\text { elections are set for early 2011, after the } \\
\text { austerity plan and a December budget is } \\
\text { passed. Standard \&Poor's lowers } \\
\text { Ireland's long-term credit rating to A } \\
\text { from AA-, citing its bailout, political } \\
\text { uncertainty, and concerns about the } \\
\text { political independence of the Bank of } \\
\text { Ireland. }\end{array}$ & Ireland & 1.35 & 0.54 & Portugal & Ireland \\
\hline $11 / 24 / 10$ & $\begin{array}{l}\text { The Spanish and Portuguese } 10 \text {-year } \\
\text { yields rise to euro-era highs after Spain } \\
\text { pays a high cost to sell short-term bills. } \\
\text { Yields on Spanish and Portuguese CDS } \\
\text { contracts also soar. The ECB buys } \\
\text { bonds on the secondary market, mainly } \\
\text { Portuguese. Ireland unveils a 4-year } \\
\text { austerity plan but rejects pressure from } \\
\text { to raise its low corporation tax rate }\end{array}$ & $\begin{array}{l}\text { Spain } \\
\text { Portugal } \\
\text { Ireland }\end{array}$ & 1.35 & $\begin{array}{l}0.00 \\
0.98 \\
0.79\end{array}$ & Portugal & Ireland \\
\hline $11 / 25 / 10$ & $\begin{array}{l}\text { Ireland's government sees its majority in } \\
\text { parliament fall to two after the } \\
\text { opposition wins a by-election in } \\
\text { Donegal. The yield on } 10 \text {-year Irish } \\
\text { sovereign bonds jump above } 9 \text { percent. }\end{array}$ & Ireland & 1.35 & 0.54 & Portugal & Ireland \\
\hline
\end{tabular}




\begin{tabular}{|c|c|c|c|c|c|c|}
\hline date & Description & News Entity & $\begin{array}{c}\text { Total } \\
\text { Reported } \\
\text { Purchases } \\
\end{array}$ & $\begin{array}{l}\text { News Entity } \\
\text { Estimated } \\
\text { Purchases }\end{array}$ & $\begin{array}{l}\text { SMP } \\
\text { Focus } \\
\text { Country }\end{array}$ & $\begin{array}{c}\text { Media } \\
\text { Focus } \\
\text { Country }\end{array}$ \\
\hline $11 / 27 / 10$ & $\begin{array}{c}\text { Tens of thousands of Irish protest } \\
\text { austerity and the bailout. Newspaper } \\
\text { poll shows } 57 \text { percent back an Irish } \\
\text { default. }\end{array}$ & Ireland & 1.97 & 0.79 & Portugal & Ireland \\
\hline $\begin{array}{c}11 / 28 / 10 \\
- \\
11 / 29 / 10\end{array}$ & $\begin{array}{l}\text { ECB and the IMF formally approve an } \\
€ 85 \text { billion Irish bailout. EU leaders } \\
\text { scale back proposals to inflict losses on } \\
\text { bond holders and discuss a permanent } \\
\text { system to resolve European debt crises. }\end{array}$ & Ireland & 1.97 & 0.79 & Portugal & Ireland \\
\hline $12 / 1 / 10$ & $\begin{array}{c}\text { Portuguese short-term debt auction } \\
\text { garnered strong demand, though at a } \\
\text { higher yield, on expanded SMP hopes. } \\
\text { This even after Standard \& Poor's put } \\
\text { Portugal on watch for a downgrade late } \\
\text { Nov. } 30 .\end{array}$ & Portugal & 1.97 & 0.98 & Portugal & Ireland \\
\hline $12 / 2 / 10$ & $\begin{array}{l}\text { Spain holds a strong bond auction on } \\
\text { expectations that the ECB will step up } \\
\text { bond purchases, but yields far exceeded } \\
\text { levels at the previous auction. }\end{array}$ & Spain & 1.97 & 0.00 & Portugal & Ireland \\
\hline $12 / 3 / 10$ & $\begin{array}{l}\text { Portuguese and Irish spreads over } \\
\text { German bunds narrow significantly after } \\
\text { a sharp increase in ECB interventions } \\
\text { into their secondary bond markets over } \\
\text { December } 1 \text { - } 3 \text {. }\end{array}$ & $\begin{array}{l}\text { Portugal } \\
\text { Ireland }\end{array}$ & 1.97 & $\begin{array}{l}0.98 \\
0.79\end{array}$ & Portugal & Ireland \\
\hline $12 / 7 / 10$ & $\begin{array}{l}\text { The } 2011 \text { Italian austerity government } \\
\text { passes in Parliament. Ireland details the } \\
\text { toughest budget on record, which } \\
\text { includes } € 6 \text { billion in tax rises and } \\
\text { spending cuts. }\end{array}$ & $\begin{array}{l}\text { Italy } \\
\text { Ireland }\end{array}$ & 2.67 & $\begin{array}{l}0.00 \\
0.80\end{array}$ & Portugal & Ireland \\
\hline $12 / 9 / 10$ & $\begin{array}{c}\text { Fitch Ratings is the first to strip Ireland } \\
\text { of its A credit status, slashing it by three } \\
\text { notches. }\end{array}$ & Ireland & 2.67 & 0.80 & Portugal & Ireland \\
\hline $12 / 10 / 10$ & $\begin{array}{l}\text { Portuguese and Irish yields rise amid } \\
\text { subdued ECB purchasing and weak } \\
\text { private-sector demand for their debt. } \\
\text { The ECB buys Portuguese and Irish debt } \\
\text { on the secondary market in clips of } € 10 \\
\text { million across the curve. }\end{array}$ & $\begin{array}{l}\text { Ireland } \\
\text { Portugal }\end{array}$ & 2.67 & $\begin{array}{l}0.80 \\
1.73\end{array}$ & Portugal & Ireland \\
\hline $12 / 14 / 10$ & $\begin{array}{l}\text { Italian Prime Minister Berlusconi } \\
\text { survives a no-confidence motion in } \\
\text { Parliament, with wide margins in the } \\
\text { upper and narrowly in the lower house. }\end{array}$ & Italy & 0.60 & 0.00 & Portugal & Ireland \\
\hline
\end{tabular}




\begin{tabular}{|c|c|c|c|c|c|c|}
\hline date & Description & News Entity & $\begin{array}{c}\text { Total } \\
\text { Reported } \\
\text { Purchases } \\
\end{array}$ & $\begin{array}{c}\text { News Entity } \\
\text { Estimated } \\
\text { Purchases }\end{array}$ & $\begin{array}{c}\text { SMP } \\
\text { Focus } \\
\text { Country }\end{array}$ & $\begin{array}{c}\text { Media } \\
\text { Focus } \\
\text { Country }\end{array}$ \\
\hline $12 / 15 / 10$ & $\begin{array}{l}\text { The Irish Parliament approves the } \\
\text { EU/IMF bailout package. The } \\
\text { opposition calls for renegotiation to } \\
\text { force losses on senior bond holders in } \\
\text { Irish banks. }\end{array}$ & Ireland & 0.60 & 0.18 & Portugal & Ireland \\
\hline $12 / 17 / 10$ & $\begin{array}{l}\text { European leaders agree to a two- } \\
\text { sentence change of the EU treaty to } \\
\text { allow for a permanent rescue fund. } \\
\text { Moody's cuts Ireland's credit rating by } \\
\text { five notches to Baa1, with a negative } \\
\text { outlook. The cut and the lack of fresh } \\
\text { ideas from an EU summit curbs investor } \\
\text { risk appetite. Irish 10-year yields end off } \\
\text { their widest levels of the day after the } \\
\text { ECB purchases small amounts of Irish } \\
\text { debt amid thin liquidity. }\end{array}$ & Ireland & 0.60 & 0.18 & Portugal & Ireland \\
\hline $12 / 21 / 10$ & $\begin{array}{l}\text { Ireland recapitalizes three of its banks } \\
\text { and subordinated bank debt holders } \\
\text { agree to an } 80 \text { percent haircut. Irish and } \\
\text { Portuguese yields rise on fears that a } \\
\text { precedence has been set for future } \\
\text { private-sector involvement in bailouts. } \\
\text { Spain forces its regions to publish more } \\
\text { financial details and announces new } \\
\text { austerity measures. Spain completes its } \\
2010 \text { funding with a T-Bill sale. }\end{array}$ & $\begin{array}{l}\text { Ireland } \\
\text { Spain }\end{array}$ & 1.12 & $\begin{array}{l}0.34 \\
0.00\end{array}$ & Portugal & Ireland \\
\hline $12 / 23 / 10$ & $\begin{array}{l}\text { Greek yields and the cost of insuring } \\
\text { against default rise after an unsourced } \\
\text { Greek newspaper claims the government } \\
\text { was seeking a possible debt restructuring } \\
\text { deal after 2013. The government } \\
\text { approves a } 2011 \text { budget. }\end{array}$ & Greece & 1.12 & 0.06 & Portugal & Ireland \\
\hline $1 / 5 / 11$ & $\begin{array}{l}\text { Portugal holds a successful auction but } \\
\text { is forced to pay sharply higher yields. } \\
\text { The auction is carefully watched for } \\
\text { signs of investor caution in } 2011 \text { to hold } \\
\text { the debt of the country widely believed } \\
\text { to be the next bailout candidate. }\end{array}$ & Portugal & 0.10 & 0.07 & Portugal & Portugal \\
\hline $1 / 7 / 11$ & $\begin{array}{l}\text { Portuguese yields reach euro-era highs } \\
\text { and banking stocks slump on market } \\
\text { conviction that it will request a bailout. } \\
\text { The ECB intervened to steady markets. } \\
\text { The Swiss National Bank confirms it } \\
\text { won't accept Portuguese government } \\
\text { securities as collateral for repurchase } \\
\text { agreements. }\end{array}$ & Portugal & 0.10 & 0.07 & Portugal & Portugal \\
\hline
\end{tabular}




\begin{tabular}{|c|c|c|c|c|c|c|}
\hline date & Description & News Entity & $\begin{array}{c}\text { Total } \\
\text { Reported } \\
\text { Purchases }\end{array}$ & $\begin{array}{l}\text { News Entity } \\
\text { Estimated } \\
\text { Purchases }\end{array}$ & $\begin{array}{l}\text { SMP } \\
\text { Focus } \\
\text { Country }\end{array}$ & $\begin{array}{l}\text { Media } \\
\text { Focus } \\
\text { Country }\end{array}$ \\
\hline $1 / 10 / 11$ & $\begin{array}{l}\text { The ECB buys Portuguese bonds as } \\
\text { market and peer pressure mount for it to } \\
\text { seek a bailout to prevent contagion } \\
\text { spreading to Spain. Rumors abound that } \\
\text { informal bailout talks had already begun } \\
\text { and that the ECB bought Greek and Irish } \\
\text { bonds too but not yet Spanish debt. }\end{array}$ & $\begin{array}{l}\text { Portugal } \\
\text { Greece } \\
\text { Ireland }\end{array}$ & 2.31 & $\begin{array}{l}1.40 \\
0.35 \\
0.58\end{array}$ & Portugal & Portugal \\
\hline $1 / 11 / 11$ & $\begin{array}{l}\text { Peripheral European yields fell a second } \\
\text { day; traders credited ECB bond } \\
\text { purchases of Portuguese, Greek, and } \\
\text { Irish debt. The ECB's presence } \\
\text { indirectly lowered Spanish and Italian } \\
\text { yields. Portugal reiterated it doesn't } \\
\text { need a bailout }\end{array}$ & $\begin{array}{c}\text { Portugal } \\
\text { Greece } \\
\text { Ireland } \\
\text { Spain } \\
\text { Italy }\end{array}$ & 2.31 & $\begin{array}{l}1.39 \\
0.35 \\
0.58 \\
0.00 \\
0.00\end{array}$ & Portugal & Portugal \\
\hline $1 / 12 / 11$ & $\begin{array}{l}\text { In its first } 2011 \text { auction, Portugal sells } \\
\text { the maximum planned at yields safely } \\
\text { below } 7 \text { percent. Portugal claims the } \\
\text { auction was evidence it doesn't need a } \\
\text { bailout but the market attributes it to } \\
\text { ECB bond purchases over the week and } \\
\text { many still believe Portugal will need a } \\
\text { bailout. }\end{array}$ & Portugal & 2.31 & 1.39 & Portugal & Portugal \\
\hline $1 / 13 / 11$ & $\begin{array}{l}\text { Peripheral yields fall after Spain and } \\
\text { Italy hold successful auctions; but } \\
\text { borrowing costs rose for Spain, Italy. }\end{array}$ & $\begin{array}{c}\text { Spain } \\
\text { Italy }\end{array}$ & 2.31 & $\begin{array}{l}0.00 \\
0.00\end{array}$ & Portugal & Portugal \\
\hline $1 / 14 / 11$ & $\begin{array}{l}\text { Fitch Ratings follows Standard \& Poor's } \\
\text { and Moody's in cutting Greece's } \\
\text { sovereign debt rating to junk. }\end{array}$ & Greece & 2.31 & 0.35 & Portugal & Portugal \\
\hline $1 / 18 / 11$ & $\begin{array}{l}\text { The leadership of the Irish prime } \\
\text { minister is challenged; he wins a vote of } \\
\text { confidence. EU leaders discuss } \\
\text { enhancing the EFSF and allowing } \\
\text { countries to borrow from it to buy their } \\
\text { own sovereign bonds. They discuss } \\
\text { preparing new bank stress tests. } \\
\text { Markets disappointed at the lack of } \\
\text { decisions. }\end{array}$ & Ireland & 0.15 & 0.04 & Portugal & Portugal \\
\hline $1 / 20 / 11$ & $\begin{array}{c}\text { A third of the Irish prime minister's } \\
\text { cabinet resigns in just over } 24 \text { hours. He } \\
\text { sets new parliamentary elections for } \\
\text { March } 11 .\end{array}$ & Ireland & 0.15 & 0.04 & Portugal & Portugal \\
\hline
\end{tabular}




\begin{tabular}{|c|c|c|c|c|c|c|}
\hline date & Description & News Entity & $\begin{array}{c}\text { Total } \\
\text { Reported } \\
\text { Purchases } \\
\end{array}$ & $\begin{array}{l}\text { News Entity } \\
\text { Estimated } \\
\text { Purchases }\end{array}$ & $\begin{array}{l}\text { SMP } \\
\text { Focus } \\
\text { Country }\end{array}$ & $\begin{array}{c}\text { Media } \\
\text { Focus } \\
\text { Country }\end{array}$ \\
\hline $1 / 21 / 11$ & $\begin{array}{l}\text { Spanish yields fall as it readies a plan } \\
\text { for its struggling savings banks, } \\
\text { bolstering sentiment towards all the } \\
\text { Eurozone's more indebted countries. } \\
\text { German benchmarks were higher on } \\
\text { expectations that the EFSF could } \\
\text { eventually be used to buy back } \\
\text { peripheral bonds. }\end{array}$ & Spain & 0.15 & 0.00 & Portugal & Portugal \\
\hline $1 / 22 / 11$ & $\begin{array}{l}\text { The Irish prime minister resigns as } \\
\text { leader of the ruling party but says he } \\
\text { will stay as premier until the } \\
\text { parliamentary election February } 25 \text {. }\end{array}$ & Ireland & 0.00 & 0.00 & $\mathrm{~N} \backslash \mathrm{A}$ & Ireland \\
\hline $1 / 23 / 11$ & $\begin{array}{l}\text { The Irish junior coalition partners pull } \\
\text { out of the government. }\end{array}$ & Ireland & 0.00 & 0.00 & $\mathrm{~N} \backslash \mathrm{A}$ & Ireland \\
\hline $1 / 30 / 11$ & $\begin{array}{l}\text { The Irish parliament approves the } \\
\text { finance bill, pushing through austerity } \\
\text { measures viewed as crucial to the } \\
\text { international bailout. }\end{array}$ & Ireland & 0.00 & 0.00 & $\mathrm{~N} \backslash \mathrm{A}$ & Ireland \\
\hline $1 / 31 / 11$ & $\begin{array}{c}\text { The Irish prime minister says he will not } \\
\text { seek re-election in parliamentary } \\
\text { elections February } 25 .\end{array}$ & Ireland & 0.00 & 0.00 & $\mathrm{~N} \backslash \mathrm{A}$ & Ireland \\
\hline $2 / 2 / 11$ & $\begin{array}{l}\text { Peripheral European yields fall as a deal } \\
\text { among EU leaders to expand financial } \\
\text { rescue measures appears likely. Standard } \\
\text { \& Poor's lowers its long-term rating for } \\
\text { Ireland from A to A-, to little market } \\
\text { reaction. }\end{array}$ & Ireland & 0.00 & 0.00 & $\mathrm{~N} \backslash \mathrm{A}$ & Ireland \\
\hline $2 / 4 / 11$ & $\begin{array}{l}\text { At an EU summit, Germany and France } \\
\text { put forward a proposal for a Eurozone } \\
\text { pact to strengthen the economy, but } \\
\text { many other states are angered by what } \\
\text { they see as a fait accompli agreed upon } \\
\text { without their input. }\end{array}$ & EU & 0.00 & 0.00 & $\mathrm{~N} \backslash \mathrm{A}$ & Ireland \\
\hline $2 / 9 / 11$ & $\begin{array}{l}\text { Ireland shelves plans to inject up to } € 10 \\
\text { billion into local banks until after the } \\
\text { election of a new government February } \\
\text { 25. Portuguese bond yields spike at a } \\
\text { debt sale. Market sentiment toward } \\
\text { peripheral debt sours quickly. }\end{array}$ & $\begin{array}{l}\text { Ireland } \\
\text { Portugal }\end{array}$ & 0.00 & $\begin{array}{l}0.00 \\
0.00\end{array}$ & Portugal & Portugal \\
\hline
\end{tabular}




\begin{tabular}{|c|c|c|c|c|c|c|}
\hline date & Description & News Entity & $\begin{array}{c}\text { Total } \\
\text { Reported } \\
\text { Purchases } \\
\end{array}$ & $\begin{array}{l}\text { News Entity } \\
\text { Estimated } \\
\text { Purchases }\end{array}$ & $\begin{array}{l}\text { SMP } \\
\text { Focus } \\
\text { Country }\end{array}$ & $\begin{array}{l}\text { Media } \\
\text { Focus } \\
\text { Country }\end{array}$ \\
\hline 2/11/11 & $\begin{array}{l}\text { EU and IMF approve next } € 15 \text { billion } \\
\text { aid tranche for Greece but urge Athens } \\
\text { to speed up reforms to meet bailout deal } \\
\text { targets. Greece aims to cut its budget } \\
\text { deficit to } € 3 \text { billion in } 2015 \text {. }\end{array}$ & Greece & 0.00 & 0.00 & Portugal & Portugal \\
\hline 2/15/11 & $\begin{array}{l}\text { Greek yields rise after new GDP data } \\
\text { shows its recession deepened in the } \\
\text { fourth quarter of 2010. The large } \\
\text { negative reaction was partially attributed } \\
\text { to disappointment that the ECB didn't } \\
\text { buy Greek bonds after the } \\
\text { announcement. }\end{array}$ & Greece & 0.60 & 0.00 & Portugal & Portugal \\
\hline 2/18/11 & $\begin{array}{l}\text { The ECB intervened in peripheral debt } \\
\text { markets by buying up shorter dated } \\
\text { Portuguese bonds, reining in five-year } \\
\text { yields from a euro-era high. A } \\
\text { comprehensive Portuguese agreement on } \\
\text { crisis-tackling measures was postponed } \\
\text { until late March. }\end{array}$ & Portugal & 0.60 & 0.60 & Portugal & Portugal \\
\hline 2/20/11 & $\begin{array}{l}\text { Germany's ruling party loses control of } \\
\text { Hamburg in the first of seven state } \\
\text { elections in 2011. In a year of } 7 \text { German } \\
\text { state elections, it is hard for Germany to } \\
\text { sign on to an expanded EFSF with } \\
\text { buyback powers as any perceived } \\
\text { relaxation of debt terms for Eurozone } \\
\text { stragglers is unpopular. }\end{array}$ & EU & 0.40 & N/A & Portugal & Portugal \\
\hline 2/23/11 & $\begin{array}{c}\text { Greek police clash with protesters as } \\
\text { around 100,000 workers, pensioners, } \\
\text { and students march on parliament to } \\
\text { protest austerity policies. Greek, } \\
\text { Portuguese, and Irish yield spreads } \\
\text { widen on February } 24 .\end{array}$ & $\begin{array}{l}\text { Greece } \\
\text { Portugal } \\
\text { Ireland }\end{array}$ & 0.40 & $\begin{array}{l}0.00 \\
0.40 \\
0.00\end{array}$ & Portugal & Portugal \\
\hline $2 / 25 / 11$ & $\begin{array}{l}\text { Ireland holds general elections. The } \\
\text { center-right Fine Gael party, led by Enda } \\
\text { Kenny, defeats the ruling Fianna Fail } \\
\text { party, in the worst result in its history. }\end{array}$ & Ireland & 0.40 & 0.00 & Portugal & Portugal \\
\hline $3 / 4 / 11$ & $\begin{array}{l}\text { Fourteen EU leaders, hosted by Finland, } \\
\text { met to prepare a comprehensive } \\
\text { response to the Eurozone debt crisis by } \\
\text { the full EU summit on March } 24 / 25 \text {. }\end{array}$ & EU & 0.00 & N/A & $\mathrm{N} \backslash \mathrm{A}$ & EU \\
\hline $3 / 9 / 11$ & $\begin{array}{c}\text { Kenny is elected Taoiseach (prime } \\
\text { minister) and pledges to lift the country } \\
\text { out of its "darkest hour." }\end{array}$ & Ireland & 0.00 & 0.00 & $\mathrm{~N} \backslash \mathrm{A}$ & EU \\
\hline
\end{tabular}




\begin{tabular}{|c|c|c|c|c|c|c|}
\hline date & Description & News Entity & $\begin{array}{c}\text { Total } \\
\text { Reported } \\
\text { Purchases } \\
\end{array}$ & $\begin{array}{c}\text { News Entity } \\
\text { Estimated } \\
\text { Purchases }\end{array}$ & $\begin{array}{c}\text { SMP } \\
\text { Focus } \\
\text { Country }\end{array}$ & $\begin{array}{l}\text { Media } \\
\text { Focus } \\
\text { Country }\end{array}$ \\
\hline 3/12/11 & $\begin{array}{l}\text { Eurozone leaders agree the capacity of } \\
\text { the EFSF should nearly double to } € 440 \\
\text { billion, but delegated to finance } \\
\text { ministers to work out how. They also } \\
\text { agree to expand powers of EFSF to } \\
\text { allow it to buy debt in primary markets. }\end{array}$ & EU & 0.00 & N/A & $\mathrm{N} \backslash \mathrm{A}$ & EU \\
\hline 3/15/11 & $\begin{array}{l}\text { Ireland reveals that unemployment rose } \\
\text { to } 14.7 \text { percent by December } 2010 \text { - its } \\
\text { highest level in } 17 \text { years, outstripping } \\
\text { expectations. EU finance ministers meet } \\
\text { to discuss details on how to bolster the } \\
\text { region's bailout fund so that the } \\
\text { reformed EFSF will be operational by } \\
\text { the summer. }\end{array}$ & Ireland & 0.00 & 0.00 & $\mathrm{~N} \backslash \mathrm{A}$ & EU \\
\hline 3/18/11 & $\begin{array}{l}\text { The ECB breaks a three-week abstention } \\
\text { from bond purchases. Traders reported } \\
\text { the Bank bought Portuguese bonds. The } \\
\text { actual disclosure of purchases is on the } \\
\text { following Monday, March } 21 \text {. The news } \\
\text { was welcomed by markets but did not } \\
\text { dispel a view that interventions were } \\
\text { reluctant. }\end{array}$ & Portugal & 0.00 & 0.00 & $\mathrm{~N} \backslash \mathrm{A}$ & EU \\
\hline 3/22/11 & $\begin{array}{l}\text { The Portuguese prime minister offers to } \\
\text { resign when he is unable to win approval } \\
\text { in parliament for the country's fourth } \\
\text { austerity package. Two-year Portuguese } \\
\text { bond yields reached their highest level } \\
\text { since } 1999 .\end{array}$ & Portugal & 0.00 & 0.00 & $\mathrm{~N} \backslash \mathrm{A}$ & Portugal \\
\hline 3/24/11 & $\begin{array}{l}\text { EU leaders confirm the EFSF will have } \\
\text { a higher effective lending capacity by } \\
\text { June. By 2013, the larger, permanent } \\
\text { European Stability Mechanism (ESM) } \\
\text { will replace the EFSF. They agree on } \\
\text { stricter debt rules and stronger euro-area } \\
\text { fiscal coordination. Portuguese 10-year } \\
\text { yields push above } 8 \text { percent, a rate seen } \\
\text { as unsustainable, after Fitch Ratings cuts } \\
\text { its rating to BBB. }\end{array}$ & Portugal & 0.00 & 0.00 & & \\
\hline 3/25/11 & $\begin{array}{l}\text { Ireland does not block the ESM deal, as } \\
\text { feared but continues to insist that the } 6 \\
\text { percent interest rate on its aid is too high } \\
\text { (Greece negotiated to } 4 \text { percent). EU } \\
\text { leaders offer to negotiate with Ireland if } \\
\text { it raises its corporate tax rate - Ireland } \\
\text { refuses. EU leaders push final approval } \\
\text { of the EFSF/ESM deal is to June. }\end{array}$ & EU & 0.00 & N/A & $\mathrm{N} \backslash \mathrm{A}$ & Portugal \\
\hline
\end{tabular}




\begin{tabular}{|c|c|c|c|c|c|c|}
\hline date & Description & News Entity & $\begin{array}{c}\text { Total } \\
\text { Reported } \\
\text { Purchases } \\
\end{array}$ & $\begin{array}{c}\text { News Entity } \\
\text { Estimated } \\
\text { Purchases }\end{array}$ & $\begin{array}{c}\text { SMP } \\
\text { Focus } \\
\text { Country }\end{array}$ & $\begin{array}{c}\text { Media } \\
\text { Focus } \\
\text { Country }\end{array}$ \\
\hline 3/29/11 & $\begin{array}{l}\text { Standard \& Poor's downgrades Portugal } \\
\text { one notch to BBB- after the Bank of } \\
\text { Portugal cut its growth forecasts for } \\
2011 \text { and 2012. JPMorgan predicts } \\
\text { Portugal will go to the EFSF by the } \\
\text { weekend. Standard \& Poor's also } \\
\text { downgrades Greece two notches to BB-. }\end{array}$ & $\begin{array}{l}\text { Portugal } \\
\text { Greece }\end{array}$ & 0.20 & $\begin{array}{l}0.20 \\
0.00\end{array}$ & Portugal & Portugal \\
\hline 3/31/11 & $\begin{array}{l}\text { Analysts warn Portugal doesn't have } \\
\text { enough money to meet its obligations. } \\
\text { Irish bank stress tests reveal its largest } \\
\text { financial institutions need billions in } \\
\text { new capital to stay viable. The ECB } \\
\text { does not announce plans for a liquidity } \\
\text { facility for Ireland's banks, despite a } \\
\text { week of negotiations. }\end{array}$ & $\begin{array}{l}\text { Portugal } \\
\text { Ireland }\end{array}$ & 0.20 & $\begin{array}{l}0.20 \\
0.00\end{array}$ & Portugal & Portugal \\
\hline $4 / 4 / 11$ & $\begin{array}{l}\text { Fitch ratings downgrades Portugal from } \\
\text { A- to BBB-. The yield on Portugal's } 10- \\
\text { year bond rises for the 10th straight } \\
\text { session, hitting a new record high }\end{array}$ & Portugal & 0.00 & 0.00 & $\mathrm{~N} \backslash \mathrm{A}$ & Portugal \\
\hline $4 / 5 / 11$ & $\begin{array}{l}\text { Moody's downgrades Portugal from A3 } \\
\text { to Baa1. }\end{array}$ & Portugal & 0.00 & 0.00 & $\mathrm{~N} \backslash \mathrm{A}$ & Portugal \\
\hline $4 / 6 / 11$ & $\begin{array}{c}\text { Portugal requests an EU bail-out after } \\
\text { paying a high price in a 12-month } \\
\text { Treasury bill auction earlier the same } \\
\text { day. }\end{array}$ & Portugal & 0.00 & 0.00 & $\mathrm{~N} \backslash \mathrm{A}$ & Portugal \\
\hline $\begin{array}{c}4 / 8 / 11- \\
4 / 9 / 11\end{array}$ & $\begin{array}{l}\text { European leaders hold an Informal } \\
\text { meeting where they urge Portugal to } \\
\text { commit to reforms in exchange for a } \\
\text { bailout. }\end{array}$ & Portugal & 0.00 & 0.00 & $\mathrm{~N} \backslash \mathrm{A}$ & Portugal \\
\hline $4 / 14 / 11$ & $\begin{array}{l}\text { The German Finance Minister becomes } \\
\text { the first senior official to acknowledge } \\
\text { that restructuring Greece's debt is a } \\
\text { possibility in an interview with a } \\
\text { German newspaper. Greek borrowing } \\
\text { costs surge to new highs. }\end{array}$ & Greece & 0.00 & 0.00 & $\mathrm{~N} \backslash \mathrm{A}$ & Greece \\
\hline $4 / 15 / 11$ & $\begin{array}{l}\text { Greece plans } € 76 \text { billion in new } \\
\text { austerity measures by } 2015 .\end{array}$ & Greece & 0.00 & 0.00 & $\mathrm{~N} \backslash \mathrm{A}$ & Greece \\
\hline $5 / 2 / 11$ & $\begin{array}{l}\text { Greece rejects debt restructuring while } \\
\text { asking that the EU and IMF agree to } \\
\text { extend its bailout loan repayments. }\end{array}$ & Greece & 0.00 & 0.00 & $\mathrm{~N} \backslash \mathrm{A}$ & Greece \\
\hline $5 / 9 / 11$ & $\begin{array}{l}\text { Standard \& Poor's cuts Greece's debt } \\
\text { rating two notches to B. }\end{array}$ & Greece & 0.00 & 0.00 & $\mathrm{~N} \backslash \mathrm{A}$ & Greece \\
\hline
\end{tabular}




\begin{tabular}{|c|c|c|c|c|c|c|}
\hline date & Description & News Entity & $\begin{array}{c}\text { Total } \\
\text { Reported } \\
\text { Purchases } \\
\end{array}$ & $\begin{array}{l}\text { News Entity } \\
\text { Estimated } \\
\text { Purchases }\end{array}$ & $\begin{array}{l}\text { SMP } \\
\text { Focus } \\
\text { Country }\end{array}$ & $\begin{array}{l}\text { Media } \\
\text { Focus } \\
\text { Country }\end{array}$ \\
\hline $5 / 11 / 11$ & $\begin{array}{l}\text { EU and IMF inspectors arrive in Greece } \\
\text { to determine if it will get a fifth aid } \\
\text { tranche of } € 12 \text { billion without which it } \\
\text { would effectively default. They indicate } \\
\text { that Greece is not doing enough to meet } \\
\text { its deficit targets, even as it faces deeper } \\
\text { recession than previous forecast. }\end{array}$ & Greece & 0.00 & 0.00 & $\mathrm{~N} \backslash \mathrm{A}$ & Greece \\
\hline $5 / 16 / 11$ & $\begin{array}{l}\text { Eurozone finance ministers approve a } \\
€ 78 \text { billion bailout for Portugal but insist } \\
\text { that it ask private bondholders to } \\
\text { maintain their exposure to its debt. }\end{array}$ & Portugal & 0.00 & 0.00 & $\mathrm{~N} \backslash \mathrm{A}$ & Greece \\
\hline $5 / 17 / 11$ & $\begin{array}{l}\text { Europe's top financial officials } \\
\text { acknowledged for the first time as a } \\
\text { group that Greece may have to } \\
\text { restructure its debts. }\end{array}$ & Greece & 0.00 & 0.00 & $\mathrm{~N} \backslash \mathrm{A}$ & Greece \\
\hline $5 / 22 / 11$ & $\begin{array}{l}\text { Spain's ruling Socialists suffer their } \\
\text { worst local election defeat in } 30 \text { years. }\end{array}$ & Spain & 0.00 & 0.00 & $\mathrm{~N} \backslash \mathrm{A}$ & Greece \\
\hline $5 / 23 / 11$ & $\begin{array}{l}\text { Greece unveils a series of } \\
\text { privatizations, part of its goal to raise } \\
€ 50 \text { billion by } 2015 \text { to pay down debt. } \\
\text { Portugal's prime minister officially steps } \\
\text { down after the opposition rejects his } \\
\text { austerity package. }\end{array}$ & $\begin{array}{l}\text { Greece } \\
\text { Portugal }\end{array}$ & 0.00 & 0.0 & $\mathrm{~N} \backslash \mathrm{A}$ & Greece \\
\hline $5 / 26 / 11$ & $\begin{array}{l}\text { The IMF will withhold Greece's June aid } \\
\text { tranche Europe will cover Greece's } 2012 \\
\text { funding needs. The EU insists it needs a } \\
\text { stronger commitment to austerity from } \\
\text { Greece first. Greece's prime minister } \\
\text { holds talks with opposition leaders to } \\
\text { win support for more austerity. }\end{array}$ & Greece & 0.00 & 0.00 & $\mathrm{~N} \backslash \mathrm{A}$ & Greece \\
\hline $6 / 1 / 11$ & $\begin{array}{c}\text { Moody's slashes Greece's credit rating } \\
\text { by three notches to move it deeper into } \\
\text { junk territory. }\end{array}$ & Greece & 0.00 & 0.00 & $\mathrm{~N} \backslash \mathrm{A}$ & Greece \\
\hline $6 / 3 / 11$ & $\begin{array}{l}\text { The EU, IMF, and ECB end a review of } \\
\text { Greece's bailout program, concluding } \\
\text { more reform is needed before they } \\
\text { release Greece's next aid tranche. They } \\
\text { discuss extra funding for Greece and, for } \\
\text { the first time, involving private sector } \\
\text { investors on a voluntary basis. Greek } \\
\text { yields fall. Protesters occupy the Greek } \\
\text { Finance Ministry. }\end{array}$ & Greece & 0.00 & 0.00 & $\mathrm{~N} \backslash \mathrm{A}$ & Greece \\
\hline
\end{tabular}




\begin{tabular}{|c|c|c|c|c|c|c|}
\hline date & Description & News Entity & $\begin{array}{c}\text { Total } \\
\text { Reported } \\
\text { Purchases }\end{array}$ & $\begin{array}{l}\text { News Entity } \\
\text { Estimated } \\
\text { Purchases }\end{array}$ & $\begin{array}{l}\text { SMP } \\
\text { Focus } \\
\text { Country }\end{array}$ & $\begin{array}{l}\text { Media } \\
\text { Focus } \\
\text { Country }\end{array}$ \\
\hline $6 / 4 / 11$ & $\begin{array}{l}\text { Greece agrees to make significant cuts } \\
\text { in public sector employment, triggering } \\
\text { further protests in central Athens. }\end{array}$ & Greece & 0.00 & 0.00 & $\mathrm{~N} \backslash \mathrm{A}$ & Greece \\
\hline $6 / 5 / 11$ & $\begin{array}{l}\text { Portugal holds general elections. The } \\
\text { outgoing prime minister quits the } \\
\text { leadership of the Socialist Party after it } \\
\text { badly lost to the center-right Social } \\
\text { Democrats lead by Pedro Coelho. }\end{array}$ & Portugal & 0.00 & 0.00 & $\mathrm{~N} \backslash \mathrm{A}$ & Greece \\
\hline $6 / 8 / 11$ & $\begin{array}{l}\text { Greece agrees to } € 6.48 \text { billion extra } \\
2011 \text { austerity measures. }\end{array}$ & Greece & 0.00 & 0.00 & $\mathrm{~N} \backslash \mathrm{A}$ & Greece \\
\hline $6 / 9 / 11$ & $\begin{array}{l}\text { Germany approves a new Greek rescue } \\
\text { package to be finalized at a June 23-24 } \\
\text { summit on the condition that private } \\
\text { bondholders share the burden. The ECB } \\
\text { opposes any private sector involvement. }\end{array}$ & Greece & 0.00 & 0.00 & $\mathrm{~N} \backslash \mathrm{A}$ & Greece \\
\hline 6/11/11 & $\begin{array}{l}\text { The head of the Eurozone finance } \\
\text { ministers backs Germany's proposal for } \\
\text { a soft restructuring of Greek debt, but } \\
\text { says any contribution from private sector } \\
\text { creditors should be voluntary. }\end{array}$ & Greece & 0.00 & 0.00 & $\mathrm{~N} \backslash \mathrm{A}$ & Greece \\
\hline 6/13/11 & $\begin{array}{l}\text { Greece holds the lowest credit rating in } \\
\text { the world after Standard \& Poor's } \\
\text { downgrades it by three notches, to CCC. }\end{array}$ & Greece & 0.00 & 0.00 & $\mathrm{~N} \backslash \mathrm{A}$ & Greece \\
\hline 6/15/11 & $\begin{array}{l}\text { Riots erupt in Athens against austerity } \\
\text { to allow Greece to continue tapping EU } \\
\text { aid. EU leaders resist talk of a default. } \\
\text { Their failure to resolve their } \\
\text { disagreements over the Greek debt crisis } \\
\text { rattles credit markets. }\end{array}$ & Greece & 0.00 & 0.00 & $\mathrm{~N} \backslash \mathrm{A}$ & Greece \\
\hline 6/17/11 & $\begin{array}{l}\text { The Greek prime minister reshuffles his } \\
\text { cabinet to include opposition party } \\
\text { members to pass an unpopular austerity } \\
\text { plan. The IMF agrees to give Greece its } \\
\text { next batch of rescue loans so it may } \\
\text { avoid bankruptcy. Germany and France } \\
\text { agree to a voluntary Greek bondholder } \\
\text { role, backing down from earlier } \\
\text { demands that bondholders be forced to } \\
\text { shoulder a substantial share of a Greek } \\
\text { rescue. }\end{array}$ & Greece & 0.00 & 0.00 & $\mathrm{~N} \backslash \mathrm{A}$ & Greece \\
\hline $6 / 22 / 11$ & $\begin{array}{l}\text { New Greek cabinet narrowly survives a } \\
\text { vote of no confidence. }\end{array}$ & Greece & 0.00 & 0.00 & $\mathrm{~N} \backslash \mathrm{A}$ & Greece \\
\hline
\end{tabular}




\begin{tabular}{|c|c|c|c|c|c|c|}
\hline date & Description & News Entity & $\begin{array}{c}\text { Total } \\
\text { Reported } \\
\text { Purchases } \\
\end{array}$ & $\begin{array}{l}\text { News Entity } \\
\text { Estimated } \\
\text { Purchases }\end{array}$ & $\begin{array}{l}\text { SMP } \\
\text { Focus } \\
\text { Country }\end{array}$ & $\begin{array}{l}\text { Media } \\
\text { Focus } \\
\text { Country }\end{array}$ \\
\hline $\begin{array}{l}6 / 23 / 11 \\
- \\
6 / 24 / 11\end{array}$ & $\begin{array}{l}\text { EU leaders endorse the treaty setting up } \\
\text { the ESM which will inaugurate mid- } \\
\text { 2013. They promise more money to help } \\
\text { Greece stave off bankruptcy, on } \\
\text { condition it enact the austerity plan } \\
\text { finalized in last-minute talks with } \\
\text { international lenders. No second bailout } \\
\text { package was passed or concretely } \\
\text { outlined. }\end{array}$ & Greece & 0.00 & 0.00 & $\mathrm{~N} \backslash \mathrm{A}$ & Greece \\
\hline $6 / 28 / 11$ & $\begin{array}{l}\text { Greek labor unions hold a 48-hour } \\
\text { strike. Rioters armed with stones and } \\
\text { clubs fought several hours with police } \\
\text { firing clouds of teargas in central } \\
\text { Athens, leaving gutted shop-fronts, } \\
\text { shattered windows and a field of debris. }\end{array}$ & Greece & 0.20 & 0.00 & Portugal & Greece \\
\hline $6 / 29 / 11$ & $\begin{array}{l}\text { A five-year austerity plan passes the } \\
\text { Greek parliament by } 155 \text { votes to } 138 \text {, } \\
\text { clearing a major hurdle to access to new } \\
\text { international funding. }\end{array}$ & Greece & 0.20 & 0.00 & Portugal & Greece \\
\hline $7 / 3 / 11$ & $\begin{array}{l}\text { Eurozone leaders approve the next } € 12 \\
\text { billion installment of Greece's bailout, } \\
\text { but signal it must expect significant } \\
\text { losses of sovereignty. Police clash with } \\
\text { protesters outside Greek parliament. } \\
\text { About } 100 \text { people are injured. }\end{array}$ & Greece & 0.00 & 0.00 & $\mathrm{~N} \backslash \mathrm{A}$ & Greece \\
\hline $7 / 6 / 11$ & $\begin{array}{l}\text { Moody's drops Portugal's debt rating to } \\
\text { junk status and says it may need a } \\
\text { second bailout. }\end{array}$ & Portugal & 0.00 & 0.00 & $N \backslash A$ & Greece \\
\hline 7/8/11 & $\begin{array}{l}\text { The IMF approves disbursement of } € 3.2 \\
\text { billion to help Greece pay its debts. } \\
\text { Yields across the periphery rise when } \\
\text { EU officials and banks do not reach a } \\
\text { consensus on private-sector involvement } \\
\text { in Greece's second bailout package. }\end{array}$ & Greece & 0.00 & 0.00 & $\mathrm{~N} \backslash \mathrm{A}$ & Greece \\
\hline $7 / 12 / 11$ & $\begin{array}{l}\text { Moody's cuts Ireland's sovereign debt } \\
\text { rating to junk. }\end{array}$ & Ireland & 0.00 & 0.00 & $\mathrm{~N} \backslash \mathrm{A}$ & Greece \\
\hline 7/13/11 & $\begin{array}{c}\text { Fitch ratings downgrades Greek } \\
\text { sovereign debt further into junk territory } \\
\text { (from B+ to CCC), citing concerns about } \\
\text { the EU and IMF dithering over a second } \\
\text { bailout package. }\end{array}$ & Greece & 0.00 & 0.00 & $\mathrm{~N} \backslash \mathrm{A}$ & Greece \\
\hline $7 / 15 / 11$ & $\begin{array}{l}\text { Italy adopts a second austerity program } \\
\text { worth over } € 48 \text { billion, aiming to bring } \\
\text { the budget into balance by } 2014 \text {. }\end{array}$ & Italy & 0.00 & 0.00 & $\mathrm{~N} \backslash \mathrm{A}$ & Greece \\
\hline
\end{tabular}




\begin{tabular}{|c|c|c|c|c|c|c|}
\hline date & Description & News Entity & $\begin{array}{c}\text { Total } \\
\text { Reported } \\
\text { Purchases }\end{array}$ & $\begin{array}{c}\text { News Entity } \\
\text { Estimated } \\
\text { Purchases }\end{array}$ & $\begin{array}{l}\text { SMP } \\
\text { Focus } \\
\text { Country }\end{array}$ & $\begin{array}{c}\text { Media } \\
\text { Focus } \\
\text { Country }\end{array}$ \\
\hline 7/16/11 & $\begin{array}{l}\text { Five Spanish banks fail "stress tests" } \\
\text { carried out by the European Banking } \\
\text { Authority to determine whether they } \\
\text { would be capable of withstanding } \\
\text { another financial crisis. Seven other } \\
\text { Spanish banks just pass the test. }\end{array}$ & Spain & 0.00 & 0.00 & $\mathrm{~N} \backslash \mathrm{A}$ & Greece \\
\hline 7/21/11 & $\begin{array}{l}\text { EU leaders approve a second Greek } \\
\text { rescue package with an extra } 1109 \\
\text { billion in aid, plus contributions by } \\
\text { private sector bondholders of } € 50 \text { billion } \\
\text { by mid-2014 (loss of } 21 \% \text { on the net } \\
\text { present value of private Greek bond } \\
\text { holdings). The EFSF rescue fund is } \\
\text { given broader powers but they do not } \\
\text { expand it, disappointing markets. }\end{array}$ & Greece & 0.00 & 0.00 & $\mathrm{~N} \backslash \mathrm{A}$ & Greece \\
\hline 7/28/11 & $\begin{array}{l}\text { Italy pays a hefty risk premium at a debt } \\
\text { auction. Markets are volatile on rumors } \\
\text { that the Italian economy minister is } \\
\text { preparing to resign after a political } \\
\text { scandal. }\end{array}$ & Italy & 0.00 & 0.00 & $\mathrm{~N} \backslash \mathrm{A}$ & $\begin{array}{l}\text { Spain } \\
\text { Italy }\end{array}$ \\
\hline 7/29/11 & $\begin{array}{l}\text { The Spanish prime minister moves } \\
\text { elections to November } 20 \text { from March } \\
2012 \text { to give his party a better chance of } \\
\text { staying in power amid growing } \\
\text { discontent. He will not seek a third term. } \\
\text { Moody’s places Spain's rating on review } \\
\text { for downgrade. }\end{array}$ & Spain & 0.00 & 0.00 & $\mathrm{~N} \backslash \mathrm{A}$ & $\begin{array}{c}\text { Spain } \\
\text { Italy }\end{array}$ \\
\hline $8 / 4 / 11$ & $\begin{array}{l}\text { The ECB leaves interest rates at } 1.5 \\
\text { percent and announces it will provide } \\
\text { liquidity to European banks. Traders } \\
\text { report the ECB entered the Irish and } \\
\text { Portuguese market. No purchases are } \\
\text { reported for this week on the ECB's } \\
\text { balance sheet. The European } \\
\text { Commission asks for an increase in the } \\
\text { EFSF's lending capacity and a license } \\
\text { for it to buy sovereign debt in secondary } \\
\text { markets. }\end{array}$ & Spain & 0.00 & 0.00 & $\begin{array}{l}\text { Portugal } \\
\text { Ireland }\end{array}$ & $\begin{array}{c}\text { Spain } \\
\text { Italy }\end{array}$ \\
\hline $8 / 5 / 11$ & $\begin{array}{c}\text { After a run on stocks and a sharp spike } \\
\text { in borrowing rates, Italy says it will } \\
\text { achieve budget balance in } 2013 \text { instead } \\
\text { of } 2014 \text { and proposes tougher austerity } \\
\text { measures. }\end{array}$ & Italy & 0.00 & 0.00 & $\begin{array}{l}\text { Portugal } \\
\text { Ireland }\end{array}$ & $\begin{array}{l}\text { Spain } \\
\text { Italy }\end{array}$ \\
\hline
\end{tabular}




\begin{tabular}{|c|c|c|c|c|c|c|}
\hline date & Description & News Entity & $\begin{array}{c}\text { Total } \\
\text { Reported } \\
\text { Purchases }\end{array}$ & $\begin{array}{c}\text { News Entity } \\
\text { Estimated } \\
\text { Purchases }\end{array}$ & $\begin{array}{c}\text { SMP } \\
\text { Focus } \\
\text { Country }\end{array}$ & $\begin{array}{c}\text { Media } \\
\text { Focus } \\
\text { Country }\end{array}$ \\
\hline $8 / 7 / 11$ & $\begin{array}{l}\text { The ECB officially announces it will } \\
\text { "actively implement" its bond-buying } \\
\text { program after a 4-month pause. } \\
\text { Germany removes hopes of a more } \\
\text { robust EFSF, saying the fund will stay } \\
\text { as agreed at the July } 21 \text { EU summit. }\end{array}$ & ECB & 22.00 & N/A & Italy & $\begin{array}{l}\text { Spain } \\
\text { Italy }\end{array}$ \\
\hline $8 / 8 / 11$ & $\begin{array}{l}\text { The ECB buys Italian and Spanish } \\
\text { bonds in size, driving yields sharply } \\
\text { lower. The ECB's purchases focus on the } \\
\text { two- to } 10 \text {-year segment but the Bank's } \\
\text { presence benefits the whole yield curve } \\
\text { in both countries. }\end{array}$ & $\begin{array}{l}\text { Italy } \\
\text { Spain }\end{array}$ & 22.00 & $\begin{array}{l}13.20 \\
8: 03\end{array}$ & Italy & $\begin{array}{l}\text { Spain } \\
\text { Italy }\end{array}$ \\
\hline $8 / 9 / 11$ & $\begin{array}{l}\text { The ECB buys Italian and Spanish debt } \\
\text { a third consecutive day. }\end{array}$ & $\begin{array}{l}\text { Italy } \\
\text { Spain }\end{array}$ & 22.00 & $\begin{array}{c}13.20 \\
8: 03\end{array}$ & Italy & $\begin{array}{l}\text { Spain } \\
\text { Italy }\end{array}$ \\
\hline $8 / 10 / 11$ & $\begin{array}{l}\text { Italy's yields fall at a Treasury bill } \\
\text { auction and it sells the full amount } \\
\text { offered. Bankers only pledge } € 65 \text { billion } \\
\text { of the } € 135 \text { billion target for private } \\
\text { write-downs on Greek debt. Greek's } \\
\text { budget deficit increases sharply on poor } \\
\text { revenue collection. German Bund } \\
\text { futures spike as investors worry about } \\
\text { French banks. Continued ECB buying } \\
\text { keeps Italian and Spanish debt markets } \\
\text { stable. }\end{array}$ & $\begin{array}{c}\text { Italy } \\
\text { Greece } \\
\text { Spain }\end{array}$ & 22.00 & $\begin{array}{c}13.20 \\
0.00 \\
8.03\end{array}$ & Italy & $\begin{array}{l}\text { Spain } \\
\text { Italy }\end{array}$ \\
\hline $8 / 11 / 11$ & $\begin{array}{l}\text { The ECB buys Italian and Spanish debt } \\
\text { in small amounts. }\end{array}$ & $\begin{array}{l}\text { Italy } \\
\text { Spain }\end{array}$ & 22.00 & $\begin{array}{l}13.20 \\
8: 03\end{array}$ & Italy & $\begin{array}{l}\text { Spain } \\
\text { Italy }\end{array}$ \\
\hline $8 / 16 / 11$ & $\begin{array}{l}\text { The ECB continues buying Italian and } \\
\text { Spanish debt. Spain pays lower yields } \\
\text { than a month ago at a Treasury bill } \\
\text { auction and Italian } 10 \text {-year yields fall } \\
\text { below } 5 \text { percent for the first time in five } \\
\text { weeks. Germany and France meet and } \\
\text { agree to increase Eurozone leader } \\
\text { meetings, add balanced-budget rules to } \\
\text { Eurozone-member constitutions, and } \\
\text { coordinate their corporate-tax regimes. } \\
\text { Markets had hoped they would establish } \\
\text { a Eurozone bond and expand the EFSF. }\end{array}$ & $\begin{array}{l}\text { Italy } \\
\text { Spain }\end{array}$ & 14.30 & $\begin{array}{l}8.57 \\
5.22\end{array}$ & Italy & $\begin{array}{l}\text { Spain } \\
\text { Italy }\end{array}$ \\
\hline
\end{tabular}




\begin{tabular}{|c|c|c|c|c|c|c|}
\hline date & Description & News Entity & $\begin{array}{c}\text { Total } \\
\text { Reported } \\
\text { Purchases }\end{array}$ & $\begin{array}{c}\text { News Entity } \\
\text { Estimated } \\
\text { Purchases }\end{array}$ & $\begin{array}{c}\text { SMP } \\
\text { Focus } \\
\text { Country }\end{array}$ & $\begin{array}{c}\text { Media } \\
\text { Focus } \\
\text { Country }\end{array}$ \\
\hline 8/18/11 & $\begin{array}{l}\text { European stock markets fall sharply. } \\
\text { Greece announces it will provide } \\
\text { Finland with collateral in exchange for } \\
\text { Finland releasing funds for its second } \\
\text { bailout. The deal must be approved by } \\
\text { all Eurozone members; many } \\
\text { immediately announce their strong } \\
\text { opposition to the plan. }\end{array}$ & Greece & 14.30 & 0.00 & Italy & $\begin{array}{c}\text { Spain } \\
\text { Italy }\end{array}$ \\
\hline 8/19/11 & $\begin{array}{l}\text { Markets are anxious other countries will } \\
\text { seek collateral on loans to Greece after } \\
\text { Finland secures a commitment, casting } \\
\text { doubts on the efficacy of Greece's } \\
\text { second bailout package. The ECB buys } \\
\text { small amounts of short-dated Italian } \\
\text { debt. Italian and Spanish } 10 \text {-year yields } \\
\text { hover just below } 5 \text { percent. }\end{array}$ & $\begin{array}{l}\text { Italy } \\
\text { Spain }\end{array}$ & 14.30 & $\begin{array}{l}8.57 \\
5.22\end{array}$ & Italy & $\begin{array}{c}\text { Spain } \\
\text { Italy }\end{array}$ \\
\hline 8/22/11 & $\begin{array}{l}\text { Italian 10-year yields rise above } 5 \\
\text { percent. The ECB enters the Italian } \\
\text { secondary market and buys in small } \\
\text { increments. }\end{array}$ & Italy & 5.30 & 3.18 & Italy & Greece \\
\hline 8/24/11 & $\begin{array}{l}\text { The French government reveals an } \\
\text { austerity plan. The second Greek bailout } \\
\text { is tabled as its creditors announce their } \\
\text { opposition to Greece's proposed bilateral } \\
\text { deal with Finland. Eurozone officials } \\
\text { explore ideas earlier rejected by Greece, } \\
\text { such as putting up state property as } \\
\text { collateral. }\end{array}$ & $\begin{array}{l}\text { France } \\
\text { Greece }\end{array}$ & 5.30 & $\begin{array}{l}0.00 \\
0.00\end{array}$ & Italy & Greece \\
\hline 8/26/11 & $\begin{array}{l}\text { Spain concludes a constitutional } \\
\text { amendment deal that will include a } \\
\text { budget deficit cap, but without a set } \\
\text { limit, and announces a new round of } \\
\text { labor market reforms. }\end{array}$ & Spain & 5.30 & 1.93 & Italy & Greece \\
\hline 8/30/11 & $\begin{array}{l}\text { The International Accounting Standards } \\
\text { Board says banks should have booked } \\
\text { bigger losses on Greek bond holdings } \\
\text { this quarter. Italian yields fall at auction } \\
\text { but weak demand indicates private- } \\
\text { sector investors are not buying and } \\
\text { Italian yields would be higher if the } \\
\text { ECB withdrew. The ECB buys Italian } \\
\text { bonds on the secondary market. The } \\
\text { Bank of Italy warns growth may be less } \\
\text { than } 1 \text { percent in } 2011 \text {. }\end{array}$ & $\begin{array}{l}\text { Greece } \\
\text { Italy }\end{array}$ & 13.30 & $\begin{array}{l}0.00 \\
7.98\end{array}$ & Italy & $\begin{array}{c}\text { Spain } \\
\text { Italy }\end{array}$ \\
\hline
\end{tabular}




\begin{tabular}{|c|c|c|c|c|c|c|}
\hline date & Description & News Entity & $\begin{array}{c}\text { Total } \\
\text { Reported } \\
\text { Purchases }\end{array}$ & $\begin{array}{c}\text { News Entity } \\
\text { Estimated } \\
\text { Purchases }\end{array}$ & $\begin{array}{c}\text { SMP } \\
\text { Focus } \\
\text { Country }\end{array}$ & $\begin{array}{c}\text { Media } \\
\text { Focus } \\
\text { Country }\end{array}$ \\
\hline $9 / 1 / 11$ & $\begin{array}{l}\text { Spain pays higher yields and attracts } \\
\text { lackluster demand at a five-year bond } \\
\text { auction despite ECB support on } \\
\text { secondary markets. Greece will miss its } \\
\text { budget deficit target for 2011; it is } \\
\text { chastised by its international lenders. } \\
\text { Greece says the miss is due to austerity- } \\
\text { induced recession. }\end{array}$ & $\begin{array}{l}\text { Spain } \\
\text { Greece }\end{array}$ & 13.30 & $\begin{array}{l}4.85 \\
0.00\end{array}$ & Italy & $\begin{array}{c}\text { Spain } \\
\text { Italy }\end{array}$ \\
\hline $9 / 5 / 11$ & $\begin{array}{l}\text { Incoming ECB President Draghi says } \\
\text { the SMP is temporary, and that Italy } \\
\text { needs to deliver on its austerity and } \\
\text { reform programs. Investors question the } \\
\text { ECB's commitment to support Italian } \\
\text { bonds, even as the ECB continues to buy } \\
\text { Italian and Spanish bonds. Yields rise } \\
\text { across peripheral Europe. }\end{array}$ & Italy & 13.86 & 9.70 & Italy & $\begin{array}{l}\text { Greece } \\
\text { Italy }\end{array}$ \\
\hline $9 / 6 / 11$ & $\begin{array}{l}\text { The Netherlands, Finland, and Germany } \\
\text { meet to discuss a deal granting Finland } \\
\text { collateral for contributing to a new } \\
\text { Greek bailout package. Italian } 10 \text {-year } \\
\text { yields retreat from 1-month highs; } \\
\text { traders cite improved risk appetite after } \\
\text { the Swiss National Bank sets a } \\
\text { minimum FX target of } 1.2 \text { francs to the } \\
\text { euro. The ECB buys small amounts of } \\
\text { Italian debt in the five to } 10 \text {-year } \\
\text { maturities. }\end{array}$ & $\begin{array}{c}\text { Greece } \\
\text { Italy }\end{array}$ & 13.86 & $\begin{array}{l}0.00 \\
9.70\end{array}$ & Italy & $\begin{array}{c}\text { Greece } \\
\text { Italy }\end{array}$ \\
\hline $9 / 7 / 11$ & $\begin{array}{l}\text { The Italian Senate approves a tough } \\
\text { austerity plan, which is interpreted as a } \\
\text { vote of confidence for the government. } \\
\text { The ECB buys small amounts of Italian } \\
\text { bonds before the vote. Germany's top } \\
\text { court rejects suits to block Berlin's } \\
\text { participation in bailouts for indebted } \\
\text { Eurozone countries. }\end{array}$ & Italy & 13.86 & 9.70 & Italy & $\begin{array}{c}\text { Greece } \\
\text { Italy }\end{array}$ \\
\hline $9 / 8 / 11$ & $\begin{array}{l}\text { Some German politicians call for a } \\
\text { Greek exit from the euro when it } \\
\text { becomes clear Greece won't meet fiscal } \\
\text { targets after its GDP contracts more than } \\
\text { expected. Greece faces the threat its EU } \\
\text { creditors will block its October bailout } \\
\text { tranche. Protests continue across Greece. }\end{array}$ & Greece & 13.86 & 0.00 & Italy & $\begin{array}{c}\text { Greece } \\
\text { Italy }\end{array}$ \\
\hline 9/9/11 & $\begin{array}{l}\text { ECB board member Stark resigns in } \\
\text { protest of the SMP. 10-year German } \\
\text { Bunds hit fresh lows while Italian yields } \\
\text { extend their rise despite ECB purchases } \\
\text { in the secondary market. }\end{array}$ & Italy & 13.86 & 9.70 & Italy & $\begin{array}{c}\text { Greece } \\
\text { Italy }\end{array}$ \\
\hline
\end{tabular}




\begin{tabular}{|c|c|c|c|c|c|c|}
\hline date & Description & News Entity & $\begin{array}{c}\text { Total } \\
\text { Reported } \\
\text { Purchases } \\
\end{array}$ & $\begin{array}{l}\text { News Entity } \\
\text { Estimated } \\
\text { Purchases }\end{array}$ & $\begin{array}{l}\text { SMP } \\
\text { Focus } \\
\text { Country }\end{array}$ & $\begin{array}{l}\text { Media } \\
\text { Focus } \\
\text { Country }\end{array}$ \\
\hline 9/12/11 & $\begin{array}{l}\text { Italian yields rise ahead of a Treasury } \\
\text { bill auction where it pays sharply higher } \\
\text { yields than at the previous auction. } \\
\text { Sovereign and bank CDS reached record } \\
\text { highs. Buyers are believed to be mainly } \\
\text { domestic institutions. }\end{array}$ & Italy & 9.89 & 6.93 & Italy & Italy \\
\hline 9/13/11 & $\begin{array}{l}\text { Italy pays higher yields than previously } \\
\text { to sell 5- to 9-year bonds and demand is } \\
\text { below the targeted amount. The ECB } \\
\text { buys Italian bonds on the secondary } \\
\text { market in the same maturities. The } \\
\text { Italian Treasury cancels the sale of an } \\
\text { ultra-long maturity bond, apparently } \\
\text { because the maturity is outside the scope } \\
\text { of the SMP. }\end{array}$ & Italy & 9.89 & 6.93 & Italy & Italy \\
\hline 9/14/11 & $\begin{array}{l}\text { Italy narrowly passes its austerity plan. } \\
\text { Italian yields fall ahead of the vote; } \\
\text { traders cite ECB purchases. Germany } \\
\text { and France tell Greece it must } \\
\text { implement reforms agreed to in its July } \\
\text { bailout plan to receive its next aid } \\
\text { trance. They affirm Greece as part of the } \\
\text { Eurozone. Fitch Ratings downgrades } \\
\text { five Spanish regions, all with negative } \\
\text { outlooks. }\end{array}$ & $\begin{array}{l}\text { Italy } \\
\text { Greece } \\
\text { Spain }\end{array}$ & 9.89 & $\begin{array}{l}6.93 \\
0.00 \\
4.02\end{array}$ & Italy & Italy \\
\hline 9/15/11 & $\begin{array}{l}\text { The European Commission cuts the } \\
\text { margin on Ireland's EFSF aid to zero. } \\
\text { Ireland expects to save } € 1.2 \text { billion per } \\
\text { year from the cut. The ECB, Fed, BOE, } \\
\text { BOJ, and SNB set up three new dollar- } \\
\text { funding operations to combat a U.S. } \\
\text { dollar shortage in the European banking } \\
\text { system. Spain pays around } 5 \text { percent for } \\
\text { all maturities sold at a long-term bond } \\
\text { auction and sells less than its targeted } \\
\text { amount. The ECB buys Spanish debt in } \\
\text { the secondary market. }\end{array}$ & $\begin{array}{l}\text { Ireland } \\
\text { Spain }\end{array}$ & 9.89 & $\begin{array}{l}0.00 \\
4.02\end{array}$ & Italy & Italy \\
\hline $\begin{array}{l}9 / 16 / 11 \\
- \\
9 / 17 / 11\end{array}$ & $\begin{array}{c}\text { No new ground is broken at an informal } \\
\text { meeting of world leaders. The US urges } \\
\text { Germany to provide more fiscal stimulus } \\
\text { for the Eurozone. Officials again warn } \\
\text { that Greece may not receive an } € 8 \\
\text { billion aid tranche in October if it fails } \\
\text { to bring its budget back in line with } \\
\text { targets. }\end{array}$ & EU & 9.89 & N/A & Italy & Italy \\
\hline $\begin{array}{l}9 / 19 / 11 \\
- \\
9 / 20 / 11\end{array}$ & $\begin{array}{l}\text { Greece holds talks with the IMF, ECB, } \\
\text { and EU on how it must cut its budget } \\
\text { deficit in order to continue receiving aid. }\end{array}$ & Greece & 3.88 & 0.00 & Italy & Greece \\
\hline
\end{tabular}




\begin{tabular}{|c|c|c|c|c|c|c|}
\hline date & Description & News Entity & $\begin{array}{c}\text { Total } \\
\text { Reported } \\
\text { Purchases }\end{array}$ & $\begin{array}{c}\text { News Entity } \\
\text { Estimated } \\
\text { Purchases }\end{array}$ & $\begin{array}{l}\text { SMP } \\
\text { Focus } \\
\text { Country }\end{array}$ & $\begin{array}{c}\text { Media } \\
\text { Focus } \\
\text { Country }\end{array}$ \\
\hline 9/20/11 & $\begin{array}{l}\text { Portugal announces it may need a } \\
\text { second bailout if Greece defaults. } \\
\text { Standard \& Poor's cuts Italy’s credit } \\
\text { rating for the first time in five years, } \\
\text { from A to A+. The opposition urges } \\
\text { prime minister Berlusconi to resign. The } \\
\text { ECB is buys Italian debt yet Italian and } \\
\text { Spanish 10-year bond yields rise above } \\
5 \text { percent. }\end{array}$ & $\begin{array}{c}\text { Portugal } \\
\text { Italy } \\
\text { Spain }\end{array}$ & 3.88 & $\begin{array}{l}0.39 \\
2.72 \\
1.27\end{array}$ & Italy & Greece \\
\hline 9/21/11 & $\begin{array}{l}\text { Portugal pays higher yields at a Treasury } \\
\text { bill auction - higher than those Greece } \\
\text { pays at a similar auction the same day - } \\
\text { yet sells its maximum targeted amount. } \\
\text { Greece adopts more austerity measures. } \\
\text { Moody's downgrades eight Greek banks } \\
\text { by two notches. The IMF says the crisis } \\
\text { has increased European banks' exposure } \\
\text { by €300 billion and they need to } \\
\text { recapitalize. Standard \& Poor's } \\
\text { downgrades seven Italian banks. }\end{array}$ & $\begin{array}{l}\text { Portugal } \\
\text { Greece } \\
\text { Italian }\end{array}$ & 3.88 & $\begin{array}{l}0.39 \\
0.00 \\
2.72\end{array}$ & Italy & Greece \\
\hline 9/22/11 & $\begin{array}{l}\text { Greeks stage a 24-hour strike, closing } \\
\text { transport systems. Greek 10-year yields } \\
\text { hit } 23.6 \text { percent, twice the rate of a year } \\
\text { earlier. Irish GDP jumps } 1.6 \text { percent in } \\
\text { quarter two on a seasonally adjusted } \\
\text { basis; the first time in five years that } \\
\text { Ireland achieves two quarters of growth. }\end{array}$ & $\begin{array}{l}\text { Greece } \\
\text { Ireland }\end{array}$ & 3.88 & $\begin{array}{l}0.00 \\
0.00\end{array}$ & Italy & Greece \\
\hline $\begin{array}{c}9 / 24 / 11 \\
- \\
9 / 25 / 11\end{array}$ & $\begin{array}{l}\text { World leaders urge a larger rescue fund } \\
\text { at the annual meeting of the World Bank } \\
\text { and the IMF. Europe is split on the form } \\
\text { the rescue plan should take. A German } \\
\text { proposal includes forced losses to } \\
\text { private bond holders of up to } 50 \% \text {, new } \\
\text { budget measures, and an appointed } \\
\text { austerity overseer with veto powers. In } \\
\text { exchange, the EU recapitalizes Greek } \\
\text { banks. }\end{array}$ & Greece & 4.16 & 0.00 & Italy & Greece \\
\hline 9/27/11 & $\begin{array}{l}\text { Greece passes an unpopular property tax } \\
\text { to receive its next aid tranche and avoid } \\
\text { bankruptcy. Police disperse protestors } \\
\text { with tear gas. Spanish yields rise at a } \\
\text { Treasury bill auction; its finance } \\
\text { minister dismisses that European leaders } \\
\text { are close to bolstering the EFSF. Italian } \\
\text { yields are higher than a month ago at a } \\
\text { short-term debt auction. The ECB } \\
\text { continues to enter the secondary market } \\
\text { to support Spanish and Italian debt. }\end{array}$ & $\begin{array}{l}\text { Greece } \\
\text { Spain } \\
\text { Italy }\end{array}$ & 4.16 & $\begin{array}{l}0.00 \\
1.21 \\
2.91\end{array}$ & Italy & Greece \\
\hline
\end{tabular}




\begin{tabular}{|c|c|c|c|c|c|c|}
\hline date & Description & News Entity & $\begin{array}{c}\text { Total } \\
\text { Reported } \\
\text { Purchases }\end{array}$ & $\begin{array}{c}\text { News Entity } \\
\text { Estimated } \\
\text { Purchases }\end{array}$ & $\begin{array}{c}\text { SMP } \\
\text { Focus } \\
\text { Country }\end{array}$ & $\begin{array}{c}\text { Media } \\
\text { Focus } \\
\text { Country }\end{array}$ \\
\hline 9/29/11 & $\begin{array}{l}\text { The EU, ECB, and IMF begin talks } \\
\text { with Greece on a plan to deepen budget } \\
\text { cuts and raise taxes. Germany approves } \\
\text { the expanded bailout fund, reducing } \\
\text { market concerns. }\end{array}$ & Greece & 4.16 & 0.00 & Italy & Greece \\
\hline 10/3/11 & $\begin{array}{l}\text { EU leaders agree to safeguard banks as } \\
\text { doubts grow about a second bailout } \\
\text { package for Greece. They postpone a } \\
\text { vital aid payment to Greece until mid- } \\
\text { November when a } 2012 \text { draft budget } \\
\text { approved by the Greek cabinet predicts a } \\
\text { deficit of } 8.5 \text { percent of GDP for } 2011 \text {, } \\
\text { short of the } 7.6 \text { percent target. }\end{array}$ & Greece & 2.36 & 0.00 & Italy & Greece \\
\hline $10 / 4 / 11$ & $\begin{array}{l}\text { Eurozone finance ministers discuss the } \\
\text { size of private sector involvement in a } \\
\text { second bailout package for Greece. } \\
\text { Yields on Italian debt fall as the ECB } \\
\text { intervenes in its secondary market. }\end{array}$ & $\begin{array}{l}\text { Greece } \\
\text { Italy }\end{array}$ & 2.36 & $\begin{array}{l}0.00 \\
1.38\end{array}$ & Italy & Greece \\
\hline 10/5/11 & $\begin{array}{l}\text { Moody's cuts Italy's rating for the first } \\
\text { time in almost two decades, lowering it } \\
\text { to A2 from Aa2, and downgrades Italy's } \\
\text { two largest banks. Plus signs that } \\
\text { Franco-Belgian bank Dexia may require } \\
\text { rescue due to its Greek exposure, this } \\
\text { confirms fears the crisis is spreading to } \\
\text { banks. Italian } 10 \text {-year yields end a touch } \\
\text { lower and Spanish } 10 \text {-year yields end } \\
\text { unchanged as the ECB buys Italian and } \\
\text { Spanish bonds. }\end{array}$ & Italy & 2.36 & 1.38 & Italy & Greece \\
\hline 10/6/11 & $\begin{array}{l}\text { Spanish yields are lower amid solid } \\
\text { demand at a 5-year bond auction. A } \\
\text { trader said private-sector investors had } \\
\text { been buying Spanish debt on the } \\
\text { secondary market prior to the auction. }\end{array}$ & Spain & 2.36 & 0.85 & Italy & Greece \\
\hline 10/7/11 & $\begin{array}{c}\text { Fitch Ratings cuts Italy's credit rating by } \\
\text { one notch to A+ and cut Spain's rating } \\
\text { one notch to AA-. Bond reaction was } \\
\text { muted amidst evident ECB activity in } \\
\text { their secondary markets. }\end{array}$ & $\begin{array}{l}\text { Italy } \\
\text { Spain }\end{array}$ & 2.36 & $\begin{array}{l}1.38 \\
0.85\end{array}$ & Italy & Greece \\
\hline $10 / 10 / 11$ & $\begin{array}{l}\text { Dexia - the largest bank to succumb to } \\
\text { the debt crisis - is broken up between } \\
\text { Belgium and France. Germany and } \\
\text { France announce a plan to shore up } \\
\text { European banks. }\end{array}$ & EU & 2.24 & N/A & Italy & $\begin{array}{l}\text { Spain } \\
\text { Italy }\end{array}$ \\
\hline $10 / 11 / 11$ & $\begin{array}{l}\text { Moody's and Fitch Ratings downgrade } \\
\text { Spanish Banks. }\end{array}$ & Italy & 2.24 & 1.35 & Italy & $\begin{array}{l}\text { Spain } \\
\text { Italy }\end{array}$ \\
\hline
\end{tabular}




\begin{tabular}{|c|c|c|c|c|c|c|}
\hline date & Description & News Entity & $\begin{array}{c}\text { Total } \\
\text { Reported } \\
\text { Purchases }\end{array}$ & $\begin{array}{c}\text { News Entity } \\
\text { Estimated } \\
\text { Purchases }\end{array}$ & $\begin{array}{c}\text { SMP } \\
\text { Focus } \\
\text { Country }\end{array}$ & $\begin{array}{c}\text { Media } \\
\text { Focus } \\
\text { Country }\end{array}$ \\
\hline $10 / 12 / 11$ & $\begin{array}{l}\text { EU leaders postpone a summit amid } \\
\text { disagreement over expanding the EFSF. } \\
\text { France supports allowing the fund to } \\
\text { issue Eurozone bonds and making it a } \\
\text { bank so it can leverage its resources; } \\
\text { Germany and the ECB vehemently } \\
\text { oppose. Italy's president and the ECB } \\
\text { publically question if Berlusconi's } \\
\text { government can pull Italy out of crisis. } \\
\text { Italian bond rise. }\end{array}$ & Italy & 2.24 & 1.35 & Italy & $\begin{array}{c}\text { Spain } \\
\text { Italy }\end{array}$ \\
\hline $10 / 13 / 11$ & $\begin{array}{l}\text { Standard \& Poor's cuts Spain's long- } \\
\text { term rating by one notch to AA- with a } \\
\text { negative outlook. The Italian Treasury } \\
\text { completes a sale of 5-year bonds near its } \\
\text { target range but pay higher yields than } \\
\text { secondary market levels before the } \\
\text { auction. The ECB buys Italian bonds } \\
\text { after auction results are announced. }\end{array}$ & $\begin{array}{c}\text { Spain } \\
\text { Italy }\end{array}$ & 2.24 & $\begin{array}{l}0.83 \\
1.35\end{array}$ & Italy & $\begin{array}{c}\text { Spain } \\
\text { Italy }\end{array}$ \\
\hline $10 / 15 / 11$ & $\begin{array}{l}\text { Tens of thousands protest Italian } \\
\text { austerity and call for Prime Minister } \\
\text { Berlusconi's resignation. The march } \\
\text { degenerates into running street battles } \\
\text { with police, injuring dozens. }\end{array}$ & Italy & 4.25 & 2.55 & Italy & $\begin{array}{l}\text { Spain } \\
\text { Italy }\end{array}$ \\
\hline $10 / 18 / 11$ & $\begin{array}{l}\text { Moody's downgrades Spanish debt by } \\
\text { two notches with a negative outlook. } \\
\text { Spain announces housing prices fell } \\
\text { further in the third quarter, a concern for } \\
\text { its embattled banks. }\end{array}$ & Spain & 4.25 & 1.57 & Italy & $\begin{array}{l}\text { Spain } \\
\text { Italy }\end{array}$ \\
\hline $10 / 20 / 11$ & $\begin{array}{l}\text { Riots erupt in Greece gives initial } \\
\text { parliamentary approval for more } \\
\text { austerity. Its international inspectors } \\
\text { speak critically of its debt reduction } \\
\text { progress but endorse Ireland's. The ECB } \\
\text { buys Italian government bonds ahead of } \\
\text { Spanish and French auctions. Spain pays } \\
\text { higher yields on all but its } 10 \text {-year bond. }\end{array}$ & $\begin{array}{l}\text { Greece } \\
\text { Italy } \\
\text { Spain } \\
\text { Ireland }\end{array}$ & 4.25 & $\begin{array}{l}0.00 \\
2.55 \\
1.57 \\
0.00\end{array}$ & Italy & $\begin{array}{c}\text { Spain } \\
\text { Italy }\end{array}$ \\
\hline $10 / 21 / 11$ & $\begin{array}{l}\text { Greece receives an aid tranche after it } \\
\text { passed more austerity yesterday; a strike } \\
\text { shuts down the country and } 74 \text { are } \\
\text { wounded. Italian } 10 \text {-year yields increase } \\
\text { to } 6.1 \text { percent on bearish bets on the } \\
\text { outcome of a weekend summit but end } \\
\text { at } 5.97 \text { percent after the ECB buys those } \\
\text { bonds in the secondary market. } \\
\text { Equivalent Spanish spreads also end } \\
\text { tighter. }\end{array}$ & $\begin{array}{l}\text { Greece } \\
\text { Italy } \\
\text { Spain }\end{array}$ & 4.25 & $\begin{array}{l}0.00 \\
2.55 \\
1.57\end{array}$ & Italy & $\begin{array}{c}\text { Spain } \\
\text { Italy }\end{array}$ \\
\hline
\end{tabular}




\begin{tabular}{|c|c|c|c|c|c|c|}
\hline date & Description & News Entity & $\begin{array}{c}\text { Total } \\
\text { Reported } \\
\text { Purchases }\end{array}$ & $\begin{array}{c}\text { News Entity } \\
\text { Estimated } \\
\text { Purchases }\end{array}$ & $\begin{array}{c}\text { SMP } \\
\text { Focus } \\
\text { Country }\end{array}$ & $\begin{array}{c}\text { Media } \\
\text { Focus } \\
\text { Country }\end{array}$ \\
\hline $\begin{array}{c}10 / 22 / 11 \\
- \\
10 / 23 / 11\end{array}$ & $\begin{array}{l}\text { EU leaders downplay expectations } \\
\text { ahead of a summit where they near an } \\
\text { agreement on bank recapitalization and } \\
\text { how to leverage the EFSF but end with } \\
\text { little tangible progress. Decisions are } \\
\text { postponed for a second, media-dubbed } \\
\text { "mystery summit" in three days. }\end{array}$ & EU & 4.00 & N/A & Italy & Italy \\
\hline $10 / 26 / 11$ & $\begin{array}{l}\text { EU leaders agree to leverage the EFSF's } \\
\text { assets to boost its firepower to } € 1 \text { trillion } \\
\text { and to recapitalize banks by requiring } \\
\text { they collectively raise } € 106 \text { billion in } \\
\text { new capital but pledge help to banks } \\
\text { unable to raise funds on private markets. }\end{array}$ & EU & 4.00 & N/A & Italy & Italy \\
\hline $10 / 27 / 11$ & $\begin{array}{l}\text { Private Greek bondholders accept a } 50 \\
\text { percent loss. A second, } € 130 \text { billion, aid } \\
\text { package for Greece is finalized. The } \\
\text { Italian prime minister presents a letter to } \\
\text { the summit promising austerity but } \\
\text { blaming rising Italian yields on EU } \\
\text { leader's indecision, his predecessors, and } \\
\text { the ECB. The ECB enters the Italian and } \\
\text { Spanish secondary markets in the 5- to } \\
10 \text {-year buckets. Those yields fall } \\
\text { sharply. }\end{array}$ & $\begin{array}{l}\text { Greece } \\
\text { Italy }\end{array}$ & 4.00 & $\begin{array}{l}0.00 \\
2.40\end{array}$ & Italy & Italy \\
\hline $10 / 28 / 11$ & $\begin{array}{l}\text { Many investors are concerned that the } \\
\text { proposed enlarged EFSF is not big } \\
\text { enough for an Italian or Spanish bailout. } \\
\text { Italy's borrowing costs hit new euro-era } \\
\text { highs at a bond auction. Italy promises } \\
\text { new reforms and denies rumors its } \\
\text { coalition government is about to } \\
\text { collapse. }\end{array}$ & Italy & 4.00 & 2.40 & Italy & Italy \\
\hline $10 / 29 / 11$ & $\begin{array}{l}\text { Michael Higgins is named president of } \\
\text { Ireland. }\end{array}$ & Ireland & 9.52 & 0.00 & Italy & $\begin{array}{l}\text { Greece } \\
\text { Italy }\end{array}$ \\
\hline $10 / 31 / 11$ & $\begin{array}{l}\text { The Greek prime minister calls a } \\
\text { surprise referendum on the second } \\
\text { bailout passed over the weekend. } \\
\text { Markets react badly. Italian 5-year } \\
\text { yields reach euro-are highs, prompting } \\
\text { the ECB to greatly increase its purchases } \\
\text { of Italian debt. Post-EU-summit } \\
\text { enthusiasm fizzles out. }\end{array}$ & $\begin{array}{l}\text { Greece } \\
\text { Italy }\end{array}$ & 9.52 & $\begin{array}{l}0.00 \\
6.47\end{array}$ & Italy & $\begin{array}{l}\text { Greece } \\
\text { Italy }\end{array}$ \\
\hline
\end{tabular}




\begin{tabular}{|c|c|c|c|c|c|c|}
\hline date & Description & News Entity & $\begin{array}{c}\text { Total } \\
\text { Reported } \\
\text { Purchases } \\
\end{array}$ & $\begin{array}{c}\text { News Entity } \\
\text { Estimated } \\
\text { Purchases }\end{array}$ & $\begin{array}{c}\text { SMP } \\
\text { Focus } \\
\text { Country }\end{array}$ & $\begin{array}{c}\text { Media } \\
\text { Focus } \\
\text { Country }\end{array}$ \\
\hline 11/1/11 & $\begin{array}{l}\text { Markets react to the Greek bailout } \\
\text { referendum. The Milan stock market } \\
\text { falls } 6.8 \text { percent - its worst session since } \\
\text { the Global Financial Crisis. The ECB } \\
\text { buys Italian and Spanish bonds. Portugal } \\
\text { requests changes to its aid package } \\
\text { agreement, but says it will meet its } 2011 \\
\text { and } 2012 \text { fiscal goals. }\end{array}$ & $\begin{array}{l}\text { Italy } \\
\text { Spain } \\
\text { Ireland }\end{array}$ & 9.52 & $\begin{array}{l}6.47 \\
2.67 \\
0.38\end{array}$ & Italy & $\begin{array}{c}\text { Greece } \\
\text { Italy }\end{array}$ \\
\hline 11/2/11 & $\begin{array}{l}\text { The Greek prime minister wins cabinet } \\
\text { backing for the bailout referendum. } \\
\text { France and Germany warn Greece it } \\
\text { won't receive more aid until it meets its } \\
\text { commitments to the Eurozone. }\end{array}$ & Greece & 9.52 & 0 & Italy & $\begin{array}{c}\text { Greece } \\
\text { Italy }\end{array}$ \\
\hline 11/3/11 & $\begin{array}{l}\text { European CDS fall after successful } \\
\text { French and Spanish bond auctions but } \\
\text { Spanish 10-year yields reach } 5.39 \\
\text { percent and Italian } 6.34 \text { percent. The } \\
\text { ECB buys the debt of both. AT ECB } \\
\text { President Draghi's first policy meeting, } \\
\text { the Bank unexpectedly cuts interest rates } \\
\text { to } 1.25 \text { percent. Draghi says the SMP is } \\
\text { both temporary and limited. The Greek } \\
\text { finance minister opposes the bailout } \\
\text { referendum. The prime minister cancels } \\
\text { it. }\end{array}$ & $\begin{array}{l}\text { Spain } \\
\text { Italy } \\
\text { Greece }\end{array}$ & 9.52 & $\begin{array}{l}2.67 \\
6.47 \\
0.00\end{array}$ & & $\begin{array}{c}\text { Greece } \\
\text { Italy }\end{array}$ \\
\hline $11 / 4 / 11$ & $\begin{array}{l}\text { At a G20 summit, Italy agrees to } \\
\text { 'humiliating' special surveillance from } \\
\text { the IMF and the EU of its reforms but } \\
\text { declines an IMF loan. Greece officially } \\
\text { confirms it has dropped referendum } \\
\text { plans on the new bailout package. } \\
\text { Ireland identifies } € 12.4 \text { billion in } \\
\text { austerity over the next four years. }\end{array}$ & $\begin{array}{l}\text { Italy } \\
\text { Greece } \\
\text { Ireland }\end{array}$ & 9.52 & $\begin{array}{l}6.47 \\
0.00 \\
0.00\end{array}$ & Italy & $\begin{array}{c}\text { Greece } \\
\text { Italy }\end{array}$ \\
\hline 11/5/11 & $\begin{array}{l}\text { Greece passes a confidence vote, } \\
\text { avoiding snap elections which would } \\
\text { have endangered Greece's second } \\
\text { bailout deal. }\end{array}$ & Greece & 3.83 & 0.00 & Italy & $\begin{array}{c}\text { Greece } \\
\text { Italy }\end{array}$ \\
\hline $11 / 6 / 11$ & $\begin{array}{l}\text { A new Greek coalition is formed } \\
\text { between the ruling party and the } \\
\text { opposition which aims to approve the } \\
\text { bailout before early elections. Under the } \\
\text { agreement the prime minister will step } \\
\text { down at elections. }\end{array}$ & Greece & 3.83 & 0.00 & Italy & $\begin{array}{c}\text { Greece } \\
\text { Italy }\end{array}$ \\
\hline
\end{tabular}




\begin{tabular}{|c|c|c|c|c|c|c|}
\hline date & Description & News Entity & $\begin{array}{c}\text { Total } \\
\text { Reported } \\
\text { Purchases } \\
\end{array}$ & $\begin{array}{l}\text { News Entity } \\
\text { Estimated } \\
\text { Purchases }\end{array}$ & $\begin{array}{l}\text { SMP } \\
\text { Focus } \\
\text { Country }\end{array}$ & $\begin{array}{c}\text { Media } \\
\text { Focus } \\
\text { Country }\end{array}$ \\
\hline 11/7/11 & $\begin{array}{l}\text { Rumors that the Italian prime minister's } \\
\text { resignation is imminent triggers a rally } \\
\text { on the stock market, while Italian } \\
\text { borrowing rates reach new records. The } \\
\text { embattled prime minister denies the } \\
\text { rumors. }\end{array}$ & Italy & 3.83 & 2.60 & Italy & $\begin{array}{c}\text { Greece } \\
\text { Italy }\end{array}$ \\
\hline 11/8/11 & $\begin{array}{l}\text { The Italian prime minister fails to } \\
\text { secure a majority in a vote on public } \\
\text { finance in the lower house, prompting } \\
\text { the president to promise that the prime } \\
\text { minister will resign after a new budget is } \\
\text { approved. Italy's yields hit record levels. }\end{array}$ & Italy & 3.83 & 2.60 & Italy & $\begin{array}{c}\text { Greece } \\
\text { Italy }\end{array}$ \\
\hline 11/9/11 & $\begin{array}{l}\text { Greek leaders agree on a new } \\
\text { government; the prime minister resigns. } \\
\text { Italy's } 10 \text {-year bond yields hit } 7 \text { percent } \\
\text { for the first time in the euro era - } \\
\text { virtually shutting domestic banks out of } \\
\text { the interbank funding market. }\end{array}$ & $\begin{array}{c}\text { Greece } \\
\text { Italy }\end{array}$ & 3.83 & $\begin{array}{l}0.00 \\
2.60\end{array}$ & Italy & $\begin{array}{c}\text { Greece } \\
\text { Italy }\end{array}$ \\
\hline $11 / 10 / 11$ & $\begin{array}{l}\text { Italy pays the highest yield on a 12- } \\
\text { month Treasury bill sale since the } \\
\text { inception of the euro, though demand } \\
\text { was solid. Prior to the auction, the ECB } \\
\text { bought Italian bonds. }\end{array}$ & Italy & 3.83 & 2.60 & Italy & $\begin{array}{c}\text { Greece } \\
\text { Italy }\end{array}$ \\
\hline $11 / 11 / 11$ & $\begin{array}{l}\text { Former ECB vice-president Papademos } \\
\text { is chosen to head Greece's new crisis } \\
\text { coalition. He says they will implement } \\
\text { the bailout deal then call elections. }\end{array}$ & Greece & 3.83 & 0.00 & Italy & $\begin{array}{c}\text { Greece } \\
\text { Italy }\end{array}$ \\
\hline $11 / 12 / 11$ & $\begin{array}{l}\text { The Italian parliament passes a new } \\
\text { austerity package and Prime Minister } \\
\text { Berlusconi resigns in favor of an } \\
\text { emergency government. Italian 10-year } \\
\text { borrowing costs fall sharply from } 7.5 \text { to } \\
6.7 \text { percent. }\end{array}$ & Italy & 7.90 & 5.372 & Italy & Italy \\
\hline 11/13/11 & $\begin{array}{l}\text { Italian prime minister Berlusconi } \\
\text { officially steps down. The President } \\
\text { nominates former European } \\
\text { Commissioner Monti to become prime } \\
\text { minister. }\end{array}$ & Italy & 7.90 & 5.372 & Italy & Italy \\
\hline $11 / 15 / 11$ & $\begin{array}{l}\text { The ECB buys Italian and Spanish } \\
\text { bonds. Italian yields ended higher on the } \\
\text { day across the curve. }\end{array}$ & $\begin{array}{l}\text { Italy } \\
\text { Spain }\end{array}$ & 7.90 & $\begin{array}{l}5.37 \\
2.21\end{array}$ & Italy & Italy \\
\hline
\end{tabular}




\begin{tabular}{|c|c|c|c|c|c|c|}
\hline date & Description & News Entity & $\begin{array}{c}\text { Total } \\
\text { Reported } \\
\text { Purchases }\end{array}$ & $\begin{array}{c}\text { News Entity } \\
\text { Estimated } \\
\text { Purchases }\end{array}$ & $\begin{array}{l}\text { SMP } \\
\text { Focus } \\
\text { Country }\end{array}$ & $\begin{array}{c}\text { Media } \\
\text { Focus } \\
\text { Country }\end{array}$ \\
\hline $11 / 16 / 11$ & $\begin{array}{l}\text { Monti is sworn in as Italian prime } \\
\text { minister to head a technocratic } \\
\text { government. The new Greek } \\
\text { government wins a vote of confidence. } \\
\text { The ECB purchases Italian and Spanish } \\
\text { bonds. Portugal's next aid tranche is } \\
\text { approved and its international lenders } \\
\text { commend its reform progress. }\end{array}$ & $\begin{array}{c}\text { Italy } \\
\text { Spain } \\
\text { Portugal }\end{array}$ & 7.90 & $\begin{array}{l}5.37 \\
2.21 \\
0.32\end{array}$ & Italy & Italy \\
\hline $11 / 17 / 11$ & $\begin{array}{l}\text { The new Italian government wins a } \\
\text { confidence vote on a new austerity } \\
\text { program. The next elections are set for } \\
\text { 2013. Ireland will cut } 23,500 \text { public } \\
\text { sector jobs over four years. }\end{array}$ & $\begin{array}{l}\text { Italy } \\
\text { Ireland }\end{array}$ & 7.90 & $\begin{array}{l}5.37 \\
0.00\end{array}$ & Italy & Italy \\
\hline $11 / 18 / 11$ & $\begin{array}{l}\text { Greece will miss its } 2011 \text { deficit targets } \\
\text { with a gap equal to } 9 \text { percent of its GDP. } \\
\text { Its } 2012 \text { budget has two targets } \\
\text { depending on the outcome of a planned } \\
€ 100 \text { billion write down. The ECB buys } \\
\text { Italian and Spanish debt which end } \\
\text { lower on the day. There are market } \\
\text { rumors the ECB will lend money to the } \\
\text { IMF to bail out peripheral European } \\
\text { countries. }\end{array}$ & $\begin{array}{l}\text { Greece } \\
\text { Italy } \\
\text { Spain }\end{array}$ & 7.90 & $\begin{array}{l}0.00 \\
5.37 \\
2.21\end{array}$ & Italy & Italy \\
\hline $11 / 20 / 11$ & $\begin{array}{l}\text { The center-right People's Party wins an } \\
\text { absolute majority in Spanish elections. } \\
\text { Rajoy replaces Zapatero as prime } \\
\text { minister. Little market reaction. }\end{array}$ & Spain & 9.62 & 2.54 & Italy & $\begin{array}{l}\text { Spain } \\
\text { Italy }\end{array}$ \\
\hline $11 / 23 / 11$ & $\begin{array}{l}\text { Greece's central bank warns it faces } \\
\text { disorderly exit from the euro and urges } \\
\text { the new government to hasten reforms. } \\
\text { GDP is forecast to shrink by } 5.5 \text { percent } \\
\text { in 2011. The ECB buys Italian and } \\
\text { Spanish short-dated bonds after } \\
\text { Germany draws significantly less bids } \\
\text { than offered at a 10-year auction. Fears } \\
\text { that the crisis is eroding Germany's safe- } \\
\text { haven status. }\end{array}$ & $\begin{array}{l}\text { Greece } \\
\text { Italy } \\
\text { Spain }\end{array}$ & 9.62 & $\begin{array}{l}0.00 \\
6.16 \\
2.54\end{array}$ & Italy & $\begin{array}{c}\text { Spain } \\
\text { Italy }\end{array}$ \\
\hline $11 / 24 / 11$ & $\begin{array}{c}\text { EU leaders demand written } \\
\text { commitments from all Greek parties } \\
\text { supporting reforms in exchange for the } \\
\text { next tranche of aid. The Greek } \\
\text { opposition resists but eventually does } \\
\text { pledge. }\end{array}$ & Greece & 9.62 & 0.00 & Italy & $\begin{array}{c}\text { Spain } \\
\text { Italy }\end{array}$ \\
\hline
\end{tabular}




\begin{tabular}{|c|c|c|c|c|c|c|}
\hline date & Description & News Entity & $\begin{array}{c}\text { Total } \\
\text { Reported } \\
\text { Purchases }\end{array}$ & $\begin{array}{c}\text { News Entity } \\
\text { Estimated } \\
\text { Purchases }\end{array}$ & $\begin{array}{c}\text { SMP } \\
\text { Focus } \\
\text { Country }\end{array}$ & $\begin{array}{c}\text { Media } \\
\text { Focus } \\
\text { Country }\end{array}$ \\
\hline $11 / 25 / 11$ & $\begin{array}{l}\text { Fitch Ratings downgrades Portugal's } \\
\text { rating from BB+ to BBB-, below } \\
\text { investment grade, with a negative } \\
\text { outlook. Standard \& Poor's downgrades } \\
\text { Belgium's long-term rating from AA+ to } \\
\text { AA. Italy pays its highest yields on } \\
\text { record to sell 6-month Treasury bills, but } \\
\text { sells the full amount targeted. }\end{array}$ & $\begin{array}{l}\text { Portugal } \\
\text { Belgium } \\
\text { Italy }\end{array}$ & 9.62 & $\begin{array}{l}0.36 \\
0.00 \\
6.16\end{array}$ & Italy & $\begin{array}{c}\text { Spain } \\
\text { Italy }\end{array}$ \\
\hline $11 / 28 / 11$ & $\begin{array}{c}\text { Belgium and Italy pay euro-era highs to } \\
\text { sell bonds. The ECB buys Italian debt } \\
\text { but Italy's } 10 \text {-year yield remains above } 7 \\
\text { percent. Dissention within the ECB } \\
\text { about the SMP - opponents say program } \\
\text { outside ECB's mandate and claim it } \\
\text { doesn't work, citing the recent rise in } \\
\text { Italian bond yields. }\end{array}$ & Italy & 3.13 & 2.13 & Italy & Italy \\
\hline $11 / 29 / 11$ & $\begin{array}{l}\text { Italy sells 3-year debt at yields above the } \\
\text { levels at which Greece, Ireland, and } \\
\text { Portugal applied for bailouts. EU leaders } \\
\text { agree on EFSF leveraging details at } \\
\text { lower levels than previously proposed } \\
\text { and begin to negotiate an EU fiscal pact. } \\
\text { They hope the ECB and IMF will } \\
\text { respond with drastic action. }\end{array}$ & Italy & 3.13 & 2.13 & Italy & Italy \\
\hline $11 / 30 / 11$ & $\begin{array}{l}\text { The ECB, Fed, BOC, BOJ, BOE, and } \\
\text { SNB set up currency swap agreements } \\
\text { to provide financial markets with } \\
\text { additional U.S. dollar liquidity. The } \\
\text { ECB intervenes to cap a rise in Italian } \\
\text { and Spanish bond yields on skepticism } \\
\text { that an EU agreement to boost the EFSF } \\
\text { will resolve the Eurozone debt crisis. }\end{array}$ & $\begin{array}{l}\text { Italy } \\
\text { Spain }\end{array}$ & 3.13 & $\begin{array}{l}2.13 \\
0.88\end{array}$ & Italy & Italy \\
\hline $12 / 1 / 11$ & $\begin{array}{l}\text { Greeks test the resolve of their new } \\
\text { government with a general strike. Under } \\
\text { EU pressure, the ECB agrees to increase } \\
\text { its role battling the debt crisis if the EU } \\
\text { will enforce tougher deficit cutting but } \\
\text { does not promise unlimited support for } \\
\text { bond markets. Yields fall across } \\
\text { peripheral Europe. }\end{array}$ & Greece & 3.13 & 0.00 & Italy & Italy \\
\hline $12 / 4 / 11$ & $\begin{array}{l}\text { The Sunday Times prints and } \\
\text { unconfirmed report that the ECB is } \\
\text { preparing a } € 1 \text { trillion cash infusion } \\
\text { scheme for the Eurozone ahead of a } \\
\text { series of crisis summits this week. }\end{array}$ & ECB & 0.63 & N/A & Italy & Italy \\
\hline
\end{tabular}




\begin{tabular}{|c|c|c|c|c|c|c|}
\hline date & Description & News Entity & $\begin{array}{c}\text { Total } \\
\text { Reported } \\
\text { Purchases } \\
\end{array}$ & $\begin{array}{l}\text { News Entity } \\
\text { Estimated } \\
\text { Purchases }\end{array}$ & $\begin{array}{l}\text { SMP } \\
\text { Focus } \\
\text { Country }\end{array}$ & $\begin{array}{l}\text { Media } \\
\text { Focus } \\
\text { Country }\end{array}$ \\
\hline $12 / 5 / 11$ & $\begin{array}{l}\text { Germany and France propose a "fiscal } \\
\text { compact" to enforce budget discipline } \\
\text { across the } 17 \text {-nation Eurozone. Italian, } \\
\text { Spanish and Portuguese yields fall. Italy } \\
\text { announces new austerity measures. The } \\
\text { world's major central banks agree to } \\
\text { lower the cost of dollar currency swaps } \\
\text { by } 50 \text { basis points. }\end{array}$ & $\begin{array}{l}\text { Italy } \\
\text { Spain } \\
\text { Portugal }\end{array}$ & 0.63 & $\begin{array}{l}0.43 \\
0.18 \\
0.06\end{array}$ & Italy & Italy \\
\hline $\begin{array}{l}12 / 5 / 11 \\
- \\
12 / 6 / 11\end{array}$ & $\begin{array}{l}\text { Ireland announces budget measures over } \\
\text { two days. Deep cuts to social welfare, } \\
\text { the health sector, and education. }\end{array}$ & Ireland & 0.63 & 0.01 & Italy & Italy \\
\hline $12 / 6 / 11$ & $\begin{array}{l}\text { Violence breaks out at protests outside } \\
\text { parliament in Athens. Some protestors } \\
\text { injured; } 38 \text { are arrested. }\end{array}$ & Greece & 0.63 & 0.00 & Italy & Italy \\
\hline $12 / 7 / 11$ & $\begin{array}{l}\text { Greece submits a } 2012 \text { budget. Cuts } \\
\text { deficit from } 9 \text { percent of GDP in } 2011 \text { to } \\
5.4 \text { percent in 2012, mostly due to the } \\
\text { write-off of debt held by banks. }\end{array}$ & Greece & 0.63 & 0.00 & Italy & Italy \\
\hline $12 / 8 / 11$ & $\begin{array}{l}\text { The ECB cuts interest rates } 25 \text { basis } \\
\text { points to } 1 \text { percent, eases collateral } \\
\text { rules, and introduces its Longer-Term } \\
\text { Refinancing Operation (LTRO) - three- } \\
\text { year liquidity tenders - for Europe’s } \\
\text { cash-starved banks. The ECB } \\
\text { discourages expectations it will } \\
\text { massively step up its SMP if the EU } \\
\text { moves towards closer fiscal union. Fitch } \\
\text { Ratings cuts Greece's credit rating to } \\
\text { BBB+ from A-, with a negative outlook. } \\
\text { Standard \& Poor's warns it may } \\
\text { downgrade most Eurozone countries if } \\
\text { tomorrow's EU summit does not yield } \\
\text { decisive anti-crisis measures. }\end{array}$ & Greece & 0.63 & 0.00 & Italy & Italy \\
\hline $12 / 9 / 11$ & $\begin{array}{l}\text { EU leaders vote on a new Eurozone } \\
\text { treaty at an all-night crisis summit. } 23 \text { of } \\
27 \text { countries agree to tighter integration } \\
\text { and strict budget rules for the single } \\
\text { currency area; Britain declines. The EU } \\
\text { adds } € 200 \text { billion to the EFSF, tightens } \\
\text { rules to curb future debts, and moves } \\
\text { forward the start of the ESM permanent } \\
\text { rescue fund to 2012. ECB Italian bond } \\
\text { buying throughout the day offsets the } \\
\text { effects of market summit } \\
\text { disappointment on Italian yields. }\end{array}$ & Italy & 0.63 & 0.43 & Italy & Italy \\
\hline
\end{tabular}




\begin{tabular}{|c|c|c|c|c|c|c|}
\hline date & Description & News Entity & $\begin{array}{c}\text { Total } \\
\text { Reported } \\
\text { Purchases }\end{array}$ & $\begin{array}{c}\text { News Entity } \\
\text { Estimated } \\
\text { Purchases }\end{array}$ & $\begin{array}{c}\text { SMP } \\
\text { Focus } \\
\text { Country }\end{array}$ & $\begin{array}{c}\text { Media } \\
\text { Focus } \\
\text { Country }\end{array}$ \\
\hline $12 / 12 / 11$ & $\begin{array}{l}\text { The ECB buys Portuguese, Italian, and } \\
\text { Irish paper. Markets are alert for } \\
\text { potential Standard \& Poor's downgrades. } \\
\text { Italian 5-year yields rise above } 7 \\
\text { percent. }\end{array}$ & $\begin{array}{l}\text { Portugal } \\
\text { Ireland } \\
\text { Italy }\end{array}$ & 3.36 & $\begin{array}{l}0.07 \\
0.07 \\
2.29\end{array}$ & Italy & Italy \\
\hline $12 / 13 / 11$ & $\begin{array}{l}\text { Both Spain and Belgium pay } \\
\text { significantly lower yields at Treasury- } \\
\text { bill sales than at their previous auctions } \\
\text { and Spain sells more than planned. The } \\
\text { ECB continues to buy Italian bonds in } \\
\text { the secondary market. Greece's public } \\
\text { deficit widens by } 5.1 \text { percent in the first } \\
11 \text { months of } 2011 \text {. }\end{array}$ & $\begin{array}{l}\text { Spain } \\
\text { Italy } \\
\text { Greece }\end{array}$ & 3.36 & $\begin{array}{l}0.94 \\
2.29 \\
0.00\end{array}$ & Italy & Italy \\
\hline $12 / 14 / 11$ & $\begin{array}{l}\text { Italian borrowing costs rise to a new } \\
\text { euro-area high after the ECB dashes } \\
\text { market hopes for an expanded SMP and } \\
\text { the EU crisis summit does not produce a } \\
\text { long-term resolution to the European } \\
\text { debt crisis. Germany pays euro-era lows } \\
\text { at bond auction. Greece outlines new } \\
\text { deficit-cutting policies. The IMF says } \\
\text { Greek reforms are behind schedule. }\end{array}$ & $\begin{array}{c}\text { Italy } \\
\text { Germany } \\
\text { Greece }\end{array}$ & 3.36 & $\begin{array}{l}2.29 \\
0.00 \\
0.00\end{array}$ & Italy & Italy \\
\hline $12 / 16 / 11$ & $\begin{array}{l}\text { Spanish bond yields fall, helped by } \\
\text { European bank's demand for sovereign } \\
\text { paper eligible as collateral for three-year } \\
\text { loans from the ECB's LTRO. Italian } \\
\text { bonds, eligible at the ECB but seen as a } \\
\text { higher credit risk, also rally but give up } \\
\text { gains. }\end{array}$ & $\begin{array}{c}\text { Spain } \\
\text { Italy }\end{array}$ & 3.36 & $\begin{array}{l}0.94 \\
2.29\end{array}$ & Italy & Italy \\
\hline $12 / 19 / 11$ & $\begin{array}{l}\text { Eurozone ministers agree to boost IMF } \\
\text { resources by } € 150 \text { billion to receive } \\
\text { more money from EU allies in return. } \\
\text { Britain does not participate and the } \\
\text { Bundesbank demands parliamentary } \\
\text { approval of the proposal. }\end{array}$ & EU & 0.06 & N/A & Italy & Italy \\
\hline $12 / 10 / 11$ & $\begin{array}{l}\text { Spain sells more Treasury bills than } \\
\text { planned at sharply lower yields than } \\
\text { previously at its last auction of } 2011 . \\
\text { Investors note the ECB's LTRO- } \\
\text { provided liquidity to banks supported } \\
\text { demand for Spanish debt. }\end{array}$ & Spain & 0.06 & 0.02 & Italy & Italy \\
\hline
\end{tabular}




\begin{tabular}{|c|c|c|c|c|c|c|}
\hline date & Description & News Entity & $\begin{array}{c}\text { Total } \\
\text { Reported } \\
\text { Purchases } \\
\end{array}$ & $\begin{array}{c}\text { News Entity } \\
\text { Estimated } \\
\text { Purchases }\end{array}$ & $\begin{array}{c}\text { SMP } \\
\text { Focus } \\
\text { Country }\end{array}$ & $\begin{array}{c}\text { Media } \\
\text { Focus } \\
\text { Country }\end{array}$ \\
\hline $12 / 21 / 11$ & $\begin{array}{l}\text { In its first LTRO, the ECB loans €489 } \\
\text { billion to } 523 \text { banks for three years at a } 1 \\
\text { percent interest rate. The ECB asks } \\
\text { banks to use the liquidity to lend to } \\
\text { businesses and to buy sovereign bonds. } \\
\text { The ECB buys Spanish and Italian debt. } \\
\text { New Spanish prime minister Rajoy is } \\
\text { sworn in. Italy's GDP shrinks } 0.2 \\
\text { percent in quarter three, deeper than } \\
\text { forecasted. }\end{array}$ & $\begin{array}{l}\text { Spain } \\
\text { Italy }\end{array}$ & 0.06 & $\begin{array}{l}0.02 \\
0.04\end{array}$ & Italy & Italy \\
\hline $12 / 22 / 11$ & $\begin{array}{l}\text { Portugal reports a budget deficit of } 4.5 \\
\text { percent in 2011, substantially lower than } \\
\text { expected; it will meet its } 2012 \text { target a } \\
\text { year early after a one-off transfer of } \\
\text { pension funds. Moody's cuts Greece's } \\
\text { rating from A2 to A1. The Italian Senate } \\
\text { passes the new government's austerity } \\
\text { package in a confidence vote. }\end{array}$ & $\begin{array}{l}\text { Portugal } \\
\text { Greece } \\
\text { Italy }\end{array}$ & 0.06 & $\begin{array}{c}0.001 \\
0.00 \\
0.04\end{array}$ & Italy & Italy \\
\hline $12 / 29 / 11$ & $\begin{array}{l}\text { Italy pays lower yields in a Treasury bill } \\
\text { auction but its bond yields rise before } \\
\text { the results are released. The ECB buys } \\
\text { Italian bonds in the secondary markets } \\
\text { after the auction. }\end{array}$ & Italy & 0.42 & 0.28 & $\begin{array}{l}\text { Portugal } \\
\text { Ireland }\end{array}$ & $\begin{array}{l}\text { Spain } \\
\text { Italy }\end{array}$ \\
\hline $12 / 30 / 11$ & $\begin{array}{l}\text { The Spanish } 2011 \text { public deficit is } 8 \\
\text { percent of GDP, above a } 6 \text { percent } \\
\text { target. Spain announces planned } 2012 \\
\text { public spending cuts and tax increases. }\end{array}$ & Spain & 0.42 & 0.12 & $\begin{array}{l}\text { Portugal } \\
\text { Ireland }\end{array}$ & $\begin{array}{l}\text { Spain } \\
\text { Italy }\end{array}$ \\
\hline $1 / 3 / 12$ & $\begin{array}{l}\text { French yields rise after Standard \& } \\
\text { Poor's puts its AAA rating on watch. } \\
\text { Spanish bonds rise when it announces its } \\
2011 \text { budget deficit will be higher than } \\
\text { previously estimated. Italian bond yields } \\
\text { ease off highs as the ECB buys its debt. }\end{array}$ & $\begin{array}{c}\text { France } \\
\text { Spain } \\
\text { Italy }\end{array}$ & 2.09 & $\begin{array}{l}0.00 \\
1.42 \\
0.59\end{array}$ & Italy & $\begin{array}{l}\text { France } \\
\text { Italy }\end{array}$ \\
\hline $1 / 4 / 12$ & $\begin{array}{l}\text { Portugal pays lower yields at a 3-month } \\
\text { Treasury bill auction. }\end{array}$ & Portugal & 2.09 & 0.04 & Italy & $\begin{array}{l}\text { France } \\
\text { Italy }\end{array}$ \\
\hline
\end{tabular}




\begin{tabular}{|c|c|c|c|c|c|c|}
\hline date & Description & News Entity & $\begin{array}{c}\text { Total } \\
\text { Reported } \\
\text { Purchases } \\
\end{array}$ & $\begin{array}{c}\text { News Entity } \\
\text { Estimated } \\
\text { Purchases }\end{array}$ & $\begin{array}{c}\text { SMP } \\
\text { Focus } \\
\text { Country }\end{array}$ & $\begin{array}{c}\text { Media } \\
\text { Focus } \\
\text { Country }\end{array}$ \\
\hline $1 / 5 / 12$ & $\begin{array}{l}\text { Italy's unemployment rate rises to } 8.6 \\
\text { percent in November, the highest level } \\
\text { since the start of the SMP. Spain } \\
\text { announces its banking sector will need } \\
€ 50 \text { billion in additional capital to deal } \\
\text { with bad property assets. Spanish and } \\
\text { Italian yields rise despite the ECB } \\
\text { buying their bonds in the secondary } \\
\text { market. }\end{array}$ & $\begin{array}{l}\text { Italy } \\
\text { Spain }\end{array}$ & 2.09 & $\begin{array}{l}1.42 \\
0.59\end{array}$ & Italy & $\begin{array}{c}\text { France } \\
\text { Italy }\end{array}$ \\
\hline $1 / 6 / 12$ & $\begin{array}{l}\text { The ECB steps into Italian markets as } \\
\text { 10-year benchmark yields pass } 7 \\
\text { percent. Italian bond spreads almost } \\
\text { wide enough to prompt the two main } \\
\text { clearing houses of Italian debt to } \\
\text { increase their margin requirements. }\end{array}$ & Italy & 2.09 & 1.42 & Italy & $\begin{array}{c}\text { France } \\
\text { Italy }\end{array}$ \\
\hline $1 / 9 / 12$ & $\begin{array}{l}\text { The ECB's LTRO last month through is } \\
\text { having a positive effect on Eurozone } \\
\text { sovereign auctions, according to a } \\
\text { Reuters poll of traders. Only short-term } \\
\text { bond and bill sales have enjoyed a } \\
\text { marked reduction in yields following the } \\
\text { ECB loans. Long-term yields have risen } \\
\text { sharply in Italy and Spain. }\end{array}$ & $\begin{array}{c}\text { Italy } \\
\text { Spain }\end{array}$ & 3.31 & $\begin{array}{l}2.25 \\
0.93\end{array}$ & Italy & $\begin{array}{c}\text { France } \\
\text { Italy }\end{array}$ \\
\hline $1 / 11 / 12$ & $\begin{array}{l}\text { Greece may need to cut its debt by an } \\
\text { additional } € 15 \text { billion even after it } \\
\text { completes a deal with private creditors } \\
\text { for a } 50 \text { percent haircut in order to } \\
\text { restore government finances to } \\
\text { sustainable levels. }\end{array}$ & Greece & 3.31 & 0.00 & Italy & $\begin{array}{c}\text { France } \\
\text { Italy }\end{array}$ \\
\hline $1 / 12 / 12$ & $\begin{array}{l}\text { Spain raises twice as much as planned } \\
\text { its first bond sale of 2012. Domestic } \\
\text { banks appear to use money borrowed } \\
\text { from the ECB's LTRO to buy its debt. } \\
\text { Italy also receives strong demand at a } \\
\text { Treasury bill auction, apparently also } \\
\text { mostly from domestic Italian banks flush } \\
\text { with ECB liquidity. The surprisingly } \\
\text { strong auctions pushed down yields in } \\
\text { both countries. }\end{array}$ & $\begin{array}{c}\text { Italy } \\
\text { Spain }\end{array}$ & 3.31 & $\begin{array}{l}2.25 \\
0.93\end{array}$ & Italy & $\begin{array}{c}\text { France } \\
\text { Italy }\end{array}$ \\
\hline
\end{tabular}




\begin{tabular}{|c|c|c|c|c|c|c|}
\hline date & Description & News Entity & $\begin{array}{c}\text { Total } \\
\text { Reported } \\
\text { Purchases }\end{array}$ & $\begin{array}{c}\text { News Entity } \\
\text { Estimated } \\
\text { Purchases }\end{array}$ & $\begin{array}{c}\text { SMP } \\
\text { Focus } \\
\text { Country }\end{array}$ & $\begin{array}{c}\text { Media } \\
\text { Focus } \\
\text { Country }\end{array}$ \\
\hline $1 / 13 / 12$ & $\begin{array}{l}\text { Italian and French yields jump on a } \\
\text { rumor that an anticipated wave of } \\
\text { downgrades from Standards \& Poor's } \\
\text { was due later in the day. The ECB buys } \\
\text { Italian bonds. Standard \& Poor's does } \\
\text { downgrade France and Austria from } \\
\text { their top AAA rating; lowers Spain, } \\
\text { Italy, and Portugal (to junk status); and } \\
\text { downgrades four other euro members } \\
\text { further. }\end{array}$ & $\begin{array}{c}\text { Italy } \\
\text { France } \\
\text { Austria } \\
\text { Spain } \\
\text { Portugal }\end{array}$ & 3.31 & $\begin{array}{l}2.25 \\
0.00 \\
0.00 \\
0.93 \\
0.07\end{array}$ & Italy & $\begin{array}{c}\text { France } \\
\text { Italy }\end{array}$ \\
\hline $1 / 16 / 12$ & $\begin{array}{l}\text { ECB purchases offset pressure on } \\
\text { Spanish and Italian yields from } \\
\text { yesterday's downgrades. Standard \& } \\
\text { Poor's downgrades the EFSF European } \\
\text { temporary bailout fund from AAA to } \\
\text { AA+; the action does not reduce the } \\
\text { EFSF's } € 440 \text { billion lending capacity. } \\
\text { The downgrade is criticized by the ECB. } \\
\text { The risk of a disorderly Greek default } \\
\text { rises when, after almost two months of } \\
\text { negotiations, banks fail to reach an } \\
\text { agreement on writing off part of the } \\
\text { Greek debt. }\end{array}$ & $\begin{array}{c}\text { Italy } \\
\text { Spain } \\
\text { Portugal } \\
\text { Greece }\end{array}$ & 3.31 & $\begin{array}{l}2.25 \\
0.93 \\
0.07 \\
0.00\end{array}$ & Italy & Portugal \\
\hline 1/17/12 & $\begin{array}{l}\text { An EFSF 6-month Treasury bill sale } \\
\text { receives solid demand, showing short- } \\
\text { term confidence in the Eurozone's rescue } \\
\text { project wasn't fazed by the fund having } \\
\text { lost its Standard \& Poor's AAA rating. } \\
\text { The fund's borrowing costs did rise. } \\
\text { Spain pays significantly lower yields } \\
\text { and sells near the maximum targeted } \\
\text { amount at a Treasury bill auction. } \\
\text { Greece pays a marginally lower yield at } \\
\text { a Treasury bill auction. }\end{array}$ & $\begin{array}{l}\text { Spain } \\
\text { Greece }\end{array}$ & 2.21 & $\begin{array}{l}0.62 \\
0.00\end{array}$ & Italy & Portugal \\
\hline 1/18/12 & $\begin{array}{l}\text { Portugal holds a successful Treasury bill } \\
\text { auction despite its junk Standard \& } \\
\text { Poor's rating, selling the maximum } \\
\text { targeted amount. Portuguese banks can } \\
\text { still submit Portuguese paper to the ECB } \\
\text { for funding operations. Portuguese 10- } \\
\text { year yields rise and the ECB buys its } \\
\text { bonds. Greece and its private creditors } \\
\text { resume talks to restructure its debt. }\end{array}$ & $\begin{array}{l}\text { Portugal } \\
\text { Greece }\end{array}$ & 2.21 & $\begin{array}{l}0.04 \\
0.00\end{array}$ & Italy & Portugal \\
\hline
\end{tabular}




\begin{tabular}{|c|c|c|c|c|c|c|}
\hline date & Description & News Entity & $\begin{array}{c}\text { Total } \\
\text { Reported } \\
\text { Purchases } \\
\end{array}$ & $\begin{array}{c}\text { News Entity } \\
\text { Estimated } \\
\text { Purchases }\end{array}$ & $\begin{array}{c}\text { SMP } \\
\text { Focus } \\
\text { Country }\end{array}$ & $\begin{array}{c}\text { Media } \\
\text { Focus } \\
\text { Country }\end{array}$ \\
\hline $1 / 19 / 12$ & $\begin{array}{l}\text { Portuguese CDS rise to a record high. } \\
\text { The ECB buys Portuguese debt in the 3- } \\
\text { to 5-year range. CDS on France, Austria, } \\
\text { and Spain were all tighter despite their } \\
\text { Standard \& Poor's downgrades. Spain } \\
\text { holds its sixth consecutive successful } \\
\text { bond auction, selling well over its target } \\
\text { range and paying mostly lower yields. } \\
\text { The success is attributed to banks flush } \\
\text { with ECB cash from the ECB's LTRO. } \\
\text { Ireland passes its fifth troika review of } \\
\text { progress under its bailout program. }\end{array}$ & $\begin{array}{c}\text { Portugal } \\
\text { France } \\
\text { Spain }\end{array}$ & 2.21 & $\begin{array}{l}0.04 \\
0.00 \\
0.62 \\
0.04\end{array}$ & Italy & Portugal \\
\hline $1 / 23 / 12$ & $\begin{array}{l}\text { Peripheral spreads over German Bunds } \\
\text { fall to 1-month lows on cautious } \\
\text { optimism that Greece will cut a deal in } \\
\text { debt swap talks. Market participants } \\
\text { report Italian and Spanish yields are also } \\
\text { lowered by ECB buying in the } \\
\text { secondary market. }\end{array}$ & $\begin{array}{l}\text { Italy } \\
\text { Spain }\end{array}$ & 0.06 & $\begin{array}{l}0 \text { (we } \\
\text { believe all } \\
\text { ECB } \\
\text { purchases } \\
\text { this week } \\
\text { were of } \\
\text { Portuguese } \\
\text { debt) }\end{array}$ & Portugal & $\begin{array}{l}\text { Greece } \\
\text { Portugal }\end{array}$ \\
\hline $1 / 24 / 12$ & $\begin{array}{l}\text { Portuguese 5-year CDS rise to a new } \\
\text { high and its bond yields remain at } \\
\text { elevated levels, stoking concerns } \\
\text { Portugal won't return to markets for } \\
\text { funding in 2013. EU leaders meet to } \\
\text { discuss Greece's bailout, an expanded } \\
\text { ESM with an earlier start, and the fiscal } \\
\text { compact. No concrete progress is made. } \\
\text { Spain sells its maximum targeted } \\
\text { amount at lower yields than a month ago } \\
\text { at a Treasury bill auction. }\end{array}$ & $\begin{array}{c}\text { Portugal } \\
\text { Greece } \\
\text { Spain }\end{array}$ & 0.06 & $\begin{array}{l}0.06 \\
0.00 \\
0.00\end{array}$ & Portugal & $\begin{array}{l}\text { Greece } \\
\text { Portugal }\end{array}$ \\
\hline $1 / 25 / 12$ & $\begin{array}{l}\text { Ireland returns to the international bond } \\
\text { market for the first time since 2010. It } \\
\text { offers investors to swap their bonds } \\
\text { maturing January 2014, the month after } \\
\text { it will exit its bail-out program, for } \\
\text { longer-dated but higher-yielding debt, to } \\
\text { reduce its funding needs at that } \\
\text { transition to market funding. Almost a } \\
\text { third of investors take up the offer. 5- } \\
\text { year Irish yields fall below } 6 \text { percent for } \\
\text { the first time since its bail-out. }\end{array}$ & Ireland & 0.06 & 0.00 & Portugal & $\begin{array}{l}\text { Greece } \\
\text { Portugal }\end{array}$ \\
\hline $1 / 26 / 12$ & $\begin{array}{l}\text { 5-year Portuguese yields and CDS rise } \\
\text { to their highest levels in the euro-era } \\
\text { amid market illiquidity. The ECB } \\
\text { purchases Portuguese bonds. Italy sells } \\
\text { its maximum targeted amount in a debt } \\
\text { auction at a lower yield than previously. } \\
\text { Most demand is attributed to domestic } \\
\text { banks with ECB LTRO money. }\end{array}$ & $\begin{array}{l}\text { Portugal } \\
\text { Italy }\end{array}$ & 0.06 & $\begin{array}{l}0.06 \\
0.00\end{array}$ & Portugal & $\begin{array}{l}\text { Greece } \\
\text { Portugal }\end{array}$ \\
\hline
\end{tabular}




\begin{tabular}{|c|c|c|c|c|c|c|}
\hline date & Description & News Entity & $\begin{array}{c}\text { Total } \\
\text { Reported } \\
\text { Purchases } \\
\end{array}$ & $\begin{array}{l}\text { News Entity } \\
\text { Estimated } \\
\text { Purchases }\end{array}$ & $\begin{array}{l}\text { SMP } \\
\text { Focus } \\
\text { Country }\end{array}$ & $\begin{array}{c}\text { Media } \\
\text { Focus } \\
\text { Country }\end{array}$ \\
\hline $1 / 27 / 12$ & $\begin{array}{c}\text { Italy sells its targeted amount of } \\
\text { Treasury bills at a lower yield than a } \\
\text { sale of comparable notes in December; } \\
\text { its yields across maturities fall. Spain } \\
\text { announces measures to reduce } \\
\text { bureaucracy for businesses and boost } \\
\text { productivity as its unemployment rate } \\
\text { hits } 22 \text { percent. Fitch Ratings } \\
\text { downgrades Italy, Spain, Belgium, } \\
\text { Cyprus, and Slovenia. It affirms } \\
\text { Ireland's BBB+ rating. All six countries } \\
\text { ratings carry a negative outlook. }\end{array}$ & $\begin{array}{l}\text { Italy } \\
\text { Spain } \\
\text { Ireland }\end{array}$ & 0.06 & $\begin{array}{l}0.00 \\
0.00 \\
0.00\end{array}$ & Portugal & $\begin{array}{l}\text { Greece } \\
\text { Portugal }\end{array}$ \\
\hline $1 / 28 / 12$ & $\begin{array}{l}\text { The Greek prime minister seeks support } \\
\text { from party leaders for painful reformsto } \\
\text { secure the debt relief deal. }\end{array}$ & Greece & 0.12 & 0.00 & Portugal & Greece \\
\hline $1 / 30 / 12$ & $\begin{array}{l}\text { Portuguese bond yields and CDS rise } \\
\text { sharply as Greece and its private } \\
\text { creditors are unable to come to an } \\
\text { agreement. The ECB is active in its its } \\
\text { secondary market. All } 27 \text { EU states but } \\
\text { the U.K. and the Czech Republic agree } \\
\text { to a "fiscal compact" for stricter budget } \\
\text { discipline. }\end{array}$ & Portugal & 0.12 & 0.12 & Portugal & Greece \\
\hline $1 / 31 / 12$ & $\begin{array}{l}\text { Portuguese yields decline at a short-term } \\
\text { debt auction and it sells almost its } \\
\text { targeted amount. Investors believe the } \\
\text { ECB's intervention over the week in } \\
\text { Portuguese bond markets lowered its } \\
\text { yields sharply from their recent highs. }\end{array}$ & Portugal & 0.12 & 0.12 & Portugal & Greece \\
\hline $2 / 1 / 12$ & $\begin{array}{l}\text { The ECB buys Portuguese debt for the } \\
\text { third day in a row. }\end{array}$ & Portugal & 0.12 & 0.12 & Portugal & Greece \\
\hline $2 / 2 / 12$ & $\begin{array}{l}\text { At auction, Spain raises above its target } \\
\text { amount and pays lower yields than at } \\
\text { previous auctions. The treaty creating } \\
\text { the ESM is signed and will become } \\
\text { active in July - a year early. EU leaders } \\
\text { plan to discuss raising its capacity in } \\
\text { March. Portuguese bond yields fall as } \\
\text { the ECB continues to buy its debt on the } \\
\text { secondary market. }\end{array}$ & Spain & 0.12 & 0.00 & Portugal & Greece \\
\hline $2 / 6 / 12$ & $\begin{array}{l}\text { EU leaders discuss a second financing } \\
\text { package for Greece. No agreement is } \\
\text { reached, more meetings are planned. } \\
\text { Italian and French } 10 \text {-year bonds end } \\
\text { modestly higher. }\end{array}$ & $\begin{array}{l}\text { Greece } \\
\text { Italy } \\
\text { France }\end{array}$ & 0.06 & $\begin{array}{l}0.00 \\
0.00 \\
0.00\end{array}$ & Portugal & Greece \\
\hline
\end{tabular}




\begin{tabular}{|c|c|c|c|c|c|c|}
\hline date & Description & News Entity & $\begin{array}{c}\text { Total } \\
\text { Reported } \\
\text { Purchases }\end{array}$ & $\begin{array}{c}\text { News Entity } \\
\text { Estimated } \\
\text { Purchases }\end{array}$ & $\begin{array}{l}\text { SMP } \\
\text { Focus } \\
\text { Country }\end{array}$ & $\begin{array}{c}\text { Media } \\
\text { Focus } \\
\text { Country }\end{array}$ \\
\hline $2 / 7 / 12$ & $\begin{array}{c}\text { The ECB purchases Portuguese debt and } \\
\text { its bond yields fall from record highs } \\
\text { attributed to Greek debt negotiation } \\
\text { delays. }\end{array}$ & Portugal & 0.06 & 0.06 & Portugal & Greece \\
\hline $2 / 8 / 12$ & $\begin{array}{c}\text { Strong demand for new Spanish long- } \\
\text { maturity bonds amid further signs that } \\
\text { the ECB's first LTRO is boosting } \\
\text { markets }\end{array}$ & Spain & 0.06 & 0.00 & Portugal & Greece \\
\hline 2/9/12 & $\begin{array}{l}\text { EU leaders agree on the austerity needed } \\
\text { from Greece to secure its second bailout, } \\
\text { lowering yields across peripheral } \\
\text { Europe. Greek unemployment is a } \\
\text { record } 20.9 \text { percent. The ECB gives } \\
\text { approval for seven national central } \\
\text { banks to expand the assets banks can use } \\
\text { as collateral when obtaining liquidity, } \\
\text { which could increase the banks who can } \\
\text { tap a second LTRO. The ECB will not } \\
\text { accept a loss on its holdings of Greek } \\
\text { bonds. }\end{array}$ & $\begin{array}{l}\text { Greece } \\
\text { Portugal }\end{array}$ & 0.06 & $\begin{array}{l}0.00 \\
0.06\end{array}$ & Portugal & Greece \\
\hline 2/10/12 & $\begin{array}{l}\text { Standard \& Poor's lowers the credit } \\
\text { rating of } 34 \text { Italian banks, including } \\
\text { Italy's largest financial institutions. The } \\
\text { Friday of the last week of SMP } \\
\text { purchases on the ECB's balance sheet. }\end{array}$ & Italy & 0.06 & 0.00 & Portugal & Greece \\
\hline 2/12/12 & $\begin{array}{l}\text { Greece endorses a new austerity deal } \\
\text { after } 10 \text { hours of debate while thousands } \\
\text { protest in Athens. Masked youths torch } \\
\text { dozens of buildings and clash with riot } \\
\text { police. }\end{array}$ & Greece & 0.00 & 0.00 & Portugal & Greece \\
\hline 2/15/12 & $\begin{array}{l}\text { Greek parties pledge to implement the } \\
\text { austerity measures. The Greek cabinet } \\
\text { agrees on measures to plug a } € 325 \\
\text { million gap in the } € 3.3 \text { billion of extra } \\
\text { budget savings for } 2012 \text {. }\end{array}$ & Greece & 0.00 & 0.00 & Portugal & Greece \\
\hline 2/21/12 & $\begin{array}{l}\text { The EU approves a second Greek rescue } \\
\text { package of } € 237 \text { billion, including } € 107 \\
\text { billion euros from a private creditor debt } \\
\text { write-off (a } 53.5 \text { percent write-down). } \\
\text { They retroactively lower bailout interest } \\
\text { rates and pass on all central bank profits } \\
\text { related to Greece until } 2020 \text {. The deal } \\
\text { should bring down Greece's debt to } \\
120.5 \text { percent of GDP by } 2020 . \\
\text { Portuguese yields fall sharply. }\end{array}$ & $\begin{array}{l}\text { Greece } \\
\text { Portugal }\end{array}$ & 0.00 & $\begin{array}{l}0.00 \\
0.00\end{array}$ & & Greece \\
\hline 2/29/12 & $\begin{array}{c}\text { The ECB holds a second LTRO } \\
\text { auction, providing } 800 \text { Eurozone banks } \\
\text { with further } € 529.5 \text { billion in cheap 3- } \\
\text { month loans. }\end{array}$ & ECB & 0.00 & N/A & & Greece \\
\hline
\end{tabular}




\begin{tabular}{|c|c|c|c|c|c|c|}
\hline date & Description & News Entity & $\begin{array}{c}\text { Total } \\
\text { Reported } \\
\text { Purchases }\end{array}$ & $\begin{array}{c}\text { News Entity } \\
\text { Estimated } \\
\text { Purchases }\end{array}$ & $\begin{array}{c}\text { SMP } \\
\text { Focus } \\
\text { Country }\end{array}$ & $\begin{array}{c}\text { Media } \\
\text { Focus } \\
\text { Country }\end{array}$ \\
\hline $3 / 2 / 12$ & $\begin{array}{l}\text { Spain sets a softer } 2012 \text { budget deficit } \\
\text { target than agreed under the EU fiscal } \\
\text { pact, citing hopes for better growth but } \\
\text { irritating Germany. }\end{array}$ & Spain & 0.00 & 0.00 & & Greece \\
\hline $3 / 6 / 12$ & $\begin{array}{c}\text { Francois Hollande defeats Nicolas } \\
\text { Sarkozy with } 51.62 \text { percent of the vote } \\
\text { in a runoff election for presidency of } \\
\text { France. }\end{array}$ & France & 0.00 & 0.00 & & Greece \\
\hline $3 / 7 / 12$ & $\begin{array}{l}\text { A group of private investors } \\
\text { representing } 40.8 \text { percent of Greece's } \\
\text { €206 billion of outstanding debt say they } \\
\text { will take part in Greece's bond swap } \\
\text { offer to private creditors. The EU and } \\
\text { IMF made a successful bond swap a pre- } \\
\text { condition for final approval of Greece's } \\
\text { second bailout. }\end{array}$ & Greece & 0.00 & 0.00 & & Greece \\
\hline $3 / 8 / 12$ & $\begin{array}{c}\text { Greece's jobless rate rises to a record } 21 \\
\text { percent in December. }\end{array}$ & Greece & 0.00 & 0.00 & & Greece \\
\hline 3/9/12 & $\begin{array}{l}\text { Greece averts an uncontrolled default } \\
\text { when a quorum of private bondholders } \\
\text { accept a debt swap (losing over half the } \\
\text { face value of their investments), cutting } \\
\text { its debt by more than } € 100 \text { billion. The } \\
\text { EU unblocks } € 35.5 \text { billion in bailout } \\
\text { funds. }\end{array}$ & Greece & 0.00 & 0.00 & & Greece \\
\hline $4 / 4 / 12$ & $\begin{array}{l}\text { New anti-austerity protests erupt in } \\
\text { Greece after a pensioner, in despair over } \\
\text { his debts, shoots himself in the head in } \\
\text { Athens' central Syntagma Square. }\end{array}$ & Greece & 0.20 & 0.00 & & Greece \\
\hline 4/11/12 & $\begin{array}{l}\text { The Greek prime minister steps down } \\
\text { after completing the debt deal with } \\
\text { Greece's private debt holders; } \\
\text { parliamentary elections set for May } 6 \text {. }\end{array}$ & Greece & 0.00 & 0.00 & & Greece \\
\hline 4/25/12 & $\begin{array}{l}\text { The IMF announces that Spain's largest } \\
\text { banks are sufficiently capitalized to } \\
\text { withstand a decline in economic } \\
\text { conditions but it pinpoints a group of } 10 \\
\text { banks that are vulnerable. }\end{array}$ & Spain & 0.00 & 0.00 & & Greece \\
\hline $5 / 6 / 12$ & $\begin{array}{l}\text { The two main Greek parties, both of } \\
\text { which signed the austerity deals, suffer } \\
\text { major losses in parliamentary elections. } \\
\text { Radical leftwing group Syriza gains. }\end{array}$ & Greece & 0.00 & 0.00 & & Greece \\
\hline
\end{tabular}




\begin{tabular}{|c|c|c|c|c|c|c|}
\hline date & Description & News Entity & $\begin{array}{c}\text { Total } \\
\text { Reported } \\
\text { Purchases } \\
\end{array}$ & $\begin{array}{l}\text { News Entity } \\
\text { Estimated } \\
\text { Purchases }\end{array}$ & $\begin{array}{l}\text { SMP } \\
\text { Focus } \\
\text { Country }\end{array}$ & $\begin{array}{c}\text { Media } \\
\text { Focus } \\
\text { Country }\end{array}$ \\
\hline $5 / 7 / 12$ & $\begin{array}{l}\text { Greece fails to form a coalition } \\
\text { government. }\end{array}$ & Greece & 0.00 & 0.00 & & Greece \\
\hline 5/10/12 & $\begin{array}{l}\text { Greece again fails to form a coalition } \\
\text { government. }\end{array}$ & Greece & 0.00 & 0.00 & & Greece \\
\hline 5/10/12 & $\begin{array}{c}\text { Spain effectively nationalizes Bankia by } \\
\text { converting a } € 4.5 \text { billion state loan into } \\
\text { equity. }\end{array}$ & Spain & 0.00 & 0.00 & & Greece \\
\hline 5/14/12 & $\begin{array}{l}\text { New attempts to form a Greek } \\
\text { government founder, raising the } \\
\text { likelihood of new elections that would } \\
\text { strengthen anti-austerity forces. }\end{array}$ & Greece & 0.00 & 0.00 & & Greece \\
\hline $5 / 15 / 12$ & $\begin{array}{l}\text { Greek leaders meet to form a } \\
\text { "technocratic" government but the talks } \\
\text { fail and the country will have to hold } \\
\text { new elections. }\end{array}$ & Greece & 0.00 & 0.00 & & Greece \\
\hline $5 / 25 / 12$ & $\begin{array}{c}\text { Bankia asks Spain for } € 19 \text { billion in } \\
\text { additional rescue funds. }\end{array}$ & Spain & 0.00 & 0.00 & & Spain \\
\hline 5/30/12 & $\begin{array}{c}\text { Germany urges Spain to accept EU aid } \\
\text { for its banks to avoid a Greek-style } \\
\text { government bailout. }\end{array}$ & Spain & 0.00 & 0.00 & & Spain \\
\hline $6 / 1 / 12$ & $\begin{array}{l}\text { Bank of Spain says } € 66.2 \text { billion of } \\
\text { capital funds left Spain in March against } \\
\text { a surplus for the same month last year. }\end{array}$ & Spain & 0.00 & 0.00 & & Spain \\
\hline $6 / 2 / 12$ & $\begin{array}{l}\text { Spain calls for EU fiscal union, a sign of } \\
\text { commitment to the budgetary rigor that } \\
\text { Germany is seeking. }\end{array}$ & Spain & 0.00 & 0.00 & & Spain \\
\hline $6 / 6 / 12$ & $\begin{array}{c}\text { Spain, Germany, and the EU } \\
\text { Commission hold telephone } \\
\text { negotiations. Spain hopes for least } \\
\text { possible public obligation on any loan to } \\
\text { plug holes in the balance sheets of its } \\
\text { banks. }\end{array}$ & Spain & 0.00 & 0.00 & & Spain \\
\hline $6 / 7 / 12$ & $\begin{array}{l}\text { Eurozone ministers hold secret } \\
\text { teleconference on rescue package for } \\
\text { Spanish banks. }\end{array}$ & Spain & 0.00 & 0.00 & & Spain \\
\hline $6 / 9 / 12$ & $\begin{array}{l}\text { Officials finalize details of an EU } \\
\text { Spanish bank rescue package and Spain } \\
\text { formally asks for } € 100 \text { billion for its } \\
\text { banks later the same day. }\end{array}$ & Spain & 0.00 & 0.00 & & Spain \\
\hline 6/18/12 & $\begin{array}{l}\text { The Greek center-right New Democracy } \\
\text { party forms a coalition backing the } \\
\text { second bailout after it wins a repeat } \\
\text { election. }\end{array}$ & Greece & 0.00 & 0.00 & & Spain \\
\hline
\end{tabular}




\begin{tabular}{|c|c|c|c|c|c|c|}
\hline date & Description & News Entity & $\begin{array}{c}\text { Total } \\
\text { Reported } \\
\text { Purchases }\end{array}$ & $\begin{array}{c}\text { News Entity } \\
\text { Estimated } \\
\text { Purchases }\end{array}$ & $\begin{array}{l}\text { SMP } \\
\text { Focus } \\
\text { Country }\end{array}$ & $\begin{array}{c}\text { Media } \\
\text { Focus } \\
\text { Country }\end{array}$ \\
\hline $8 / 2 / 12$ & $\begin{array}{l}\text { The ECB announces its Outright } \\
\text { Monetary Transactions (OMT) } \\
\text { program which can make massive } \\
\text { purchases in European secondary } \\
\text { sovereign bond markets, under certain } \\
\text { conditions. Purchases commence once a } \\
\text { government asks for assistance and end } \\
\text { once "objectives are achieved" or when } \\
\text { there is non-compliance with the } \\
\text { macroeconomic adjustment program. } \\
\text { The SMP is officially terminated. }\end{array}$ & ECB & 0.00 & 0.00 & & Spain \\
\hline
\end{tabular}

